ELI LORIA

\title{
Estrutura e função do capital social na companhia aberta
}

FACULDADE DE DIREITO DA UNIVERSIDADE DE SÃO PAULO São Paulo - 2009 
ELI LORIA

\title{
Estrutura e função do capital social na companhia aberta
}

\author{
Departamento de Direito Comercial \\ Orientador: Professor Doutor Newton De Lucca
}

Trabalho apresentado à Faculdade de Direito da Universidade de São Paulo, como requisito para a obtenção do título de Mestre no programa de pós-graduação.

FACULDADE DE DIREITO DA UNIVERSIDADE DE SÃO PAULO São Paulo - 2009 
Com muito carinho, dedico esta dissertação a minha mulher Leila e a meu filho Daniel. 


\section{Agradecimentos}

Registro profunda gratidão ao meu orientador Professor Doutor Newton De Lucca cuja convivência muito me engrandece e estimula.

Agradeço igualmente aos Professores Doutores Francisco Satiro de Souza Júnior e Paulo Fernando Campos Salles de Toledo pelas valiosas observações feitas no exame de qualificação que muito me auxiliaram na versão final deste texto.

Agradeço aos Professores Doutores Eros Roberto Grau, Erasmo Valladão Azevedo e Novaes França, Paula Andréa Forgioni, Mauro Rodrigues Penteado e Paulo Salvador Frontini pelos ensinamentos ao longo do curso.

Agradeço aos amigos Hélio Rubens de Oliveira Mendes, Ilene Patrícia Noronha Najjarian, Márcia Tanji, Marcos Galileu Lorena Dutra, Flavia Hana Masuko Hotta, Eduardo Del Nero Berlendis e Margareth Noda pelas palavras de incentivo e pela permanente troca de idéias.

Agradeço a Leila e a Daniel pelo apoio e pela paciência com que me suportaram nestes anos de estudo. 


\section{Resumo}

A inovação financeira, caracterizada pela criação de novas estruturas e instrumentos jurídicos e financeiros nas últimas décadas, impactam os tradicionais conceitos do direito societário e a própria interpretação das normas vigentes. Assim, a partir do estudo das acepções e funções exercidas pelo capital social, buscou-se confrontá-lo com instrumentos criados para obtenção de recursos para as companhias bem como com alternativas para a proteção dos credores. O presente trabalho explora o tema buscando de início identificar a origem das formas associativas e o precedente histórico da companhia aberta para, em seguida, adentrar na disciplina jurídica do capital social, suas características e propósitos. Então, por fim, trata-se, em capítulos apartados, da securitização de créditos, da desconsideração da personalidade jurídica e do patrimônio de afetação, procedendo-se a uma comparação com o instituto do capital social, sem concentração específica na disciplina desses instrumentos. 


\begin{abstract}
Financial innovation, characterized by the development of new structures and legal and financial instruments in the past decades, impacts the traditional concepts of corporate law, as well as the interpretation of existing legislation. Starting from an analysis of the different meanings and functions of the legal capital of companies, it was sought to specifically examine this concept in light of mechanisms devised for the funding of companies and for the protection of creditors. This paper analyzes the matters seeking, initially, to identify the forms of association and the historical background of the publiclyheld company in order to then analyze the rules pertaining to the legal capital, with its characteristics and purposes. Last, we examine, in separate chapters, of credit securitization, of the lifting of the corporate veil, and of the segregated capital, comparing each of these concepts with that of the legal capital, instead of focusing on the specific legal rules pertaining to such concepts.
\end{abstract}




\section{Índice}

Introdução 1

Capítulo 1. Arcabouço histórico da formação da sociedade anônima 5

Capítulo 2. Capital social: noções gerais 28

2.1. Capital social e limitação da responsabilidade 28

2.2. Responsabilidade limitada e publicidade dos atos sociais 29

2.3. Capital social e patrimônio 30

2.4. A tutela legal do capital social: regime geral 33

2.5. O sistema de constituição do capital social na Lei nº 6.404/76 34

2.5.1. Alteração do capital social 34

2.5.2. Os bens aptos a serem subscritos $\quad 35$

2.5.3. As regras de avaliação dos bens 36

2.5.4. A transferência de bens à sociedade e a responsabilidade 37 do subscritor

2.6. Capital social e reservas 38

2.7. A essencialidade do instituto, segundo o sistema legal 39

2.8. As acepções do capital social $\quad 40$

2.8.1. O conceito contábil de capital 41

2.8.2. O capital social como soma das contribuições dos sócios 43

2.8.3. O capital social como cifra formal e abstrata 44

2.8.4. O capital social como capital nominal e capital real 45

2.9. As funções do capital social 46

2.9.1. A função de garantia $\quad 47$

2.9.1.1. O capital mínimo e a subcapitalização societária $\quad 51$

2.9.2. A função política $\quad 59$

2.9.3. A função de produtividade 63

2.10. Lições de direito comparado $\quad 64$

2.10.1. O desenvolvimento do instituto nos Estados Unidos 64

2.10.2. O desenvolvimento do instituto na Europa Continental 68

2.10.2.1. As características e as críticas ao modelo instituído 68 pela Segunda Diretiva 77/91/CEE do Conselho

2.10.2.2. A reforma legislativa de 2006 
3.1. A securitização de créditos 75

3.2. A perspectiva do mercado 77

3.3. As vantagens da securitização 78

3.4. A regulamentação da securitização por intermédio das companhias 79 securitizadoras

3.5. A securitização no mercado imobiliário e o patrimônio separado 83

3.6. O Fundo de Investimento em Direitos Creditórios - FIDC 85

3.7. Os problemas gerados pela securitização 90

3.8. Capital social e securitização 92

Capítulo 4. Desconsideração da personalidade jurídica 93

4.1. A personalização dos entes coletivos, a limitação da 93 responsabilidade e a teoria da desconsideração da personalidade jurídica

4.2. A tese dos custos da limitação da responsabilidade e a do abuso da 100 personalidade

4.3. Capital social e desconsideração da personalidade jurídica 102

Capítulo 5. O patrimônio de afetação e a segregação do risco 104

5.1. Patrimônio 104

5.1.1. Conceito 104

5.1.2. Teorias sobre patrimônio 105

5.1.3 Responsabilidade patrimonial 107

5.1.4. Sistema de preferência de créditos 108

5.2. A separação patrimonial e as regras do patrimônio de afetação 109

5.2.1. A evolução legislativa nacional 112

5.2.2. Da constituição e administração do patrimônio de afetação 116

5.2.3. Da extinção do patrimônio de afetação 118

5.3. Patrimônio de afetação e capital social 118

$\begin{array}{lr}\text { Conclusões } & 120\end{array}$

$\begin{array}{ll}\text { Bibliografia } & 125\end{array}$ 


\section{Introdução}

A criação de novas estruturas e instrumentos jurídicos e financeiros caracteriza o final do século XX e o início deste século, impactando os tradicionais conceitos do direito societário e a própria interpretação das normas vigentes.

Assim, a idéia desenvolvida nesta dissertação é, a partir do estudo das acepções e funções exercidas pelo capital social, confrontá-lo com instrumentos como a securitização de créditos, a desconsideração da personalidade jurídica e o patrimônio de afetação que foram erigidos tanto como forma de obtenção de recursos para as companhias, para o bom desenvolvimento da atividade produtiva, quanto outros que foram criados como forma de incremento na proteção dos credores.

O que se pretende, portanto, é uma comparação das soluções que o ordenamento dispõe, sem concentração específica na disciplina dos institutos, que aqui são apresentados em breve nota, pontuando o mais importante para a discussão.

Dessa maneira, entende-se ser possível observar se houve uma evolução com fins a tornar obsoleto o instituto do capital social, ou se então, a demanda do mundo empresarial fez apenas surgir instrumentos cuja disciplina complementa as funções daquele instituto.

Nesse sentido, entendeu-se necessário buscar os primórdios das formas associativas, com o intuito de achar o germe fundacional das sociedades de capital e, por consequência, da companhia aberta, objeto deste estudo.

Em verdade, visando manter a objetividade e a brevidade, não se buscou montar uma estrutura rígida dos momentos de evolução das tais formas associativas, mas sim mostrar um panorama de desenvolvimento destas, de maneira clara e direta, sem descuidar dos rigores metodológicos, quase como se fosse uma conversa com o leitor.

Assim, no primeiro capítulo, tratando desse panorama histórico, começamos a nossa explanação pela societas romana. Em verdade, percebe-se na societas publicanorum já o germe para a limitação da responsabilidade, traço fundamental identificado na sociedade empresária moderna.

Com efeito, tal entidade era concebida para a realização de empreendimentos que demandavam grande soma de capital, mormente as obras públicas, propiciando já a limitação da responsabilidade dos seus sócios, os chamados publicani. 
Após a queda do Império Romano e o vazio produtivo da Alta e da Baixa Idade Média, a Idade Moderna traz novos modelos societários que, seguindo a linha das Corporações Eclesiásticas, cristalizam a idéia da personalização jurídica, com todos os benefícios que o instituto consagrava, entre os quais a concreção de um patrimônio separado destinado ao desenvolvimento de uma atividade específica.

Cabe esclarecer que a denominação de patrimônio separado, conforme encontrada em grande parte da doutrina clássica, diz respeito ao aporte que uma pessoa física faz de uma soma de bens para a criação de um ente para se lançar aos negócios, e não à técnica de separação patrimonial que fazem as pessoas jurídicas para afetarem bens determinados visando a realização de um empreendimento específico.

Em seguida, aborda-se a discussão acerca do verdadeiro instituto originador da sociedade anônima, se o Banco de São Jorge ou se as Companhias Colonizadoras.

O segundo capítulo aborda o instituto do capital social. De início, e até em função do que se desenvolveu no primeiro capítulo, trata-se das imbricações entre capital social e a limitação da responsabilidade das formas associativas. Depois, se procede a uma comparação entre este instituto e o do patrimônio social, destacando-se a fixidez e a imutabilidade de um e a flexibilidade e a variabilidade do outro.

$\grave{A}$ frente, estuda-se a tutela legal do capital social de acordo com as disposições da lei societária nacional acerca da composição (quais bens aptos a serem subscritos e as regras de avaliação destes), bem como sobre as regras de alteração. Lastreado nesse estudo, trata-se da essencialidade do instituto em razão das disposições legais, vale dizer: busca-se entender se, em razão das regras ali dispostas (em uma perspectiva de lege lata somente), há, de fato, a necessidade da presença do instituto na companhia aberta.

Posteriormente, o capital social é analisado em suas acepções básicas, quais sejam: a do capital social como cifra contábil, que enxerga o instituto como uma entidade puramente contábil, que consta do passivo; a do capital social como soma das contribuições dos sócios, que, dividindo parte da doutrina, se expressa tanto pelo lado formal, que o entende como cifra representativa das contribuições dos sócios, quanto pelo lado material, que o entende como conjunto de bens provindos das contribuições dos sócios.

Há ainda aquela que entende o capital social como cifra formal e abstrata, apartada da realidade, um puro nomen iuris; e a que, enxergando a multiplicidade do instituto, o compreende segundo as noções de capital social formal, ou seja, o capital como 
cifra constante do balanço e a de capital social real, que foca os bens destinados a cobrir tal cifra.

Estudam-se também as funções do capital social. Em primeiro lugar tem-se a função de garantia dos credores, isto é, analisa-se a idéia segundo a qual o instituto do capital social, em contrapartida à limitação da responsabilidade dos sócios, funciona como reserva para garantia das obrigações assumidas pela sociedade.

Depois, é analisada a função política exercida pelo capital, ou seja, aquela que, baseada na propriedade de uma determinada cota do capital social detida pelo sócio, permite o exercício de determinadas prerrogativas.

Analisa-se, ainda, a função de produtividade, entendida desde a perspectiva da existência de uma capitalização adequada da empresa, com fins a garantir o exercício da atividade produtiva.

Toda essa estrutura, e principalmente a noção de essencialidade, é analisada nas suas implicações no direito comparado americano e europeu (e a opção por não se dividir o estudo pelos países europeus, como comumente se faz, é porque grande parte da disciplina acerca do capital social é de índole comunitária). Isso porquanto a discussão lá, a despeito de ser bem maior e mais antiga, levou a rumos diversos as conclusões nas duas regiões, podendo servir de fio à nossa conclusão.

Partindo das funções do capital social, são elaborados os últimos capítulos. Tais capítulos tratam precisamente dos institutos que hoje se concretizam em instrumentos adicionais à garantia dos credores, bem como à manutenção da atividade produtiva, e que, embora não sejam isentos de problemas, tampouco são desprovidos de virtudes.

Assim, é analisado o instituto da securitização de créditos, pelo qual o empresário deixa de expor o capital social aos efeitos das dívidas advindas da capitalização da empresa, obtendo receitas de uma fonte menos onerosa que os empréstimos.

Nesse capítulo, de maneira breve e objetiva, analisam-se as formas mais corriqueiras de se proceder à securitização, isto é, por meio de uma sociedade de propósito específico e via a utilização de um fundo de direitos creditórios, bem como as vantagens e desvantagens da operação (ou, conforme doutrina específica, desse contrato).

Analisa-se também o instituto da desconsideração da personalidade jurídica, pelo qual é possível, em determinados casos, buscar a exigibilidade das obrigações diretamente frente aos sócios. Nesse capítulo apresenta-se a discussão existente sobre a motivação da desconsideração, se fundamentada num problema existente na limitação da responsabilidade, ou se esteada numa utilização fraudulenta da pessoa jurídica. 
Por último, analisa-se o instituto do patrimônio de afetação, pelo qual se segrega o risco da atividade produtiva com a criação de um patrimônio separado, afeto a um determinado fim.

A técnica de separação patrimonial é analisada em razão das suas benesses e limitações, mormente no que respeita à tutela dos credores sociais, em comparação com a disciplina do patrimônio geral, para a qual contribui o instituto do capital social.

É de se notar, ainda, que, ao final de cada um dos capítulos específicos, fazse uma comparação com o instituto do capital social, buscando a integração e a coesão da temática abordada. 


\section{Capítulo 1. Arcabouço histórico da formação da sociedade anônima}

A história da formação da sociedade anônima é a história da interação do modelo jurídico com o universo econômico em que atuava. É o retrato do fenômeno jurídico moldando o ambiente econômico. O interessante daí é notar que as sociedades comerciais são manifestações do fenômeno associativo e apresentam aspecto dúplice, já que exteriorizam tanto um fenômeno social, quanto um fenômeno jurídico ${ }^{1}$.

O interesse comum que une os esforços dos particulares pode ser de várias naturezas, inclusive econômico. No caso das sociedades comerciais, tem-se a produção de bens de natureza econômica ${ }^{2}$. O surgimento do modelo social de companhia não é fenômeno cuja criação possa ser atribuída a um só povo, senão que recebeu contribuição de todos os modos de produção durante seu período de formação. E esse período de formação remonta já ao período antigo.

Com efeito, na Antiguidade quase toda a atividade produtiva que se desenvolvia era agropastoril, exercida numa perspectiva familiar de produção para subsistência, havendo troca do excedente. Não obstante a inventividade dos gregos e a eficiência dos romanos fossem mais do que o suficiente para fazerem com que a economia greco-romana fosse a mais auspiciosa da História Antiga, os maiores empreendimentos dos gregos e dos romanos não estavam no campo econômico, conforme verificaremos adiante.

As condições sociais da época eram favoráveis, a população tinha crescido e estendido sua expectativa de vida, que, embora curta, não ficava atrás dos maiores impérios da antiguidade. A elite nas cidades romanas e na maior parte da área do império vivia no luxo; uma substancial classe média vivia confortavelmente; trabalhadores e aldeões, embora em condições piores, não sofriam de má nutrição ${ }^{3}$.

Nessa época - principalmente período helênico e na Roma Antiga -, empregava-se o capital em negócios visando a lucros comuns, ainda que os titulares dos recursos não pertencessem à mesma família. As associações romanas não eram propícias ao comércio. Este era praticado por escravos e filius familiae e o direito se detinha mais

\footnotetext{
${ }^{1}$ Nesse sentido, pertinente a observação de Alfredo LAMY FILHO e José Luís Bulhões PEDREIRA "Em direito 'sociedade comercial' significa organização produtiva que reveste alguma das formas jurídicas típicas criadas pelos comerciantes para o exercício em comum de suas atividades. A expressão também é empregada para representar o sistema jurídico que organiza normativamente a associação que tem por objeto alguma das atividades reguladas pelo direito comercial", in A Lei das S.A., vol. I: pressupostos, elaboração $e$ modificações. $3^{\mathrm{a}}$ ed. Rio de Janeiro: Renovar, 1997, p. 22.

${ }^{2}$ Cf. DE LUCCA, Newton e SIMÃO FILHO, Adalberto (coord.). Comentários à nova lei de recuperação de empresas e de falência. São Paulo: Quartier Latin, 2005, p. 26.

${ }^{3}$ Cf. LOPEZ, Robert S. The commercial revolution of the middle ages, 950-1350. Cambridge: Cambridge University Press, 2005, p. 2.
} 
com a propriedade imobiliária. Os bens móveis (e o comércio que com eles se fazia) eram considerados res vilis ${ }^{4}$.

O escopo dos empreendimentos comerciais era restrito não só pela negligência normal das economias subdesenvolvidas, mas também por limitações peculiares aos campos onde as maiores recompensas eram possíveis - bens indispensáveis às massas e bens de luxo aos mais ricos. O governo tinha, ainda, grande participação na produção e distribuição de sal, grãos, metais, mármore e uniformes militares; limitava, ainda, por meio da lei, o comércio exterior. O comércio, embora respeitado como um trabalho fundamental, era considerado indigno à cultura de cavalheiros, mas não realmente indecoroso aos comuns, incapazes de encontrar outros meios por onde se sustentar. Isso fez com que não fosse necessário reconhecer personalidade jurídica ao núcleo de negócio, senão que as obrigações eram consideradas como havidas entre os sócios, e entre estes e terceiros, segundo uma perspectiva meramente contratual.

Conforme LOPEZ, os romanos não eram racistas $^{5}$ e, sob seu domínio, diversas nações tornaram-se uma só e os encargos e os benefícios da cidadania romana foram estendidos a todos os homens livres dessa vasta comunidade. Isso, associado à formação de um grande império que se alongou por mais de dois séculos, aos baixos tributos, à segurança e a quase inquebrantável paz interna acabou levando à abertura de excelentes oportunidades econômicas. Segundo o mesmo autor, deixaram passar, no entanto, a maior de todas as oportunidades - o crescimento econômico.

A societas romana representava um acordo entre os cidadãos para participarem dos lucros e das perdas de um empreendimento. Ali cada sócio precisava assinar um contrato para ser responsabilizado por ele. A responsabilidade era pro rata e a lei romana não fazia distinção entre obrigações e bens do sócio e os da sociedade, fazendo tábula rasa das regras de separação patrimonial entre proprietário e sociedade que caracterizam as sociedades modernas ${ }^{6}$.

Max $\mathrm{WEBER}^{7}$, aos analisar a societas, destaca o fato das obrigações entre as partes contratantes concernirem, além de contribuições decorrentes da força de trabalho,

\footnotetext{
${ }^{4}$ Nas palavras de LAMY FILHO e PEDREIRA: “ (...) o direito romano era baseada na conservação, e não na acumulação de riqueza, era pré-ordenado para o gozo dos bens, e não para o lucro”; in ob. cit., p. 24. ${ }^{5}$ Cf. ob. cit., p.2.

${ }^{6}$ HANSMANN, Henry, KRAAKMAN, Reinier e SQUIRE, Richard. Law and the Rise of the Firm, set/2005, disponível no site http://www.usc.edu/schools/college/crcc/private/ierc/Law_and_the_Rise_of_the_Firm.pdf, p.19 consultado em 16/09/07.

${ }^{7}$ In The history of commercial partnership in the middle ages, trad. Lutz Kaelber. New York: Rowman \& Little Field Publishers, Inc. 2003, p. 54.
} 
à solidariedade em relação às despesas de um sócio cuja causa esteja vinculada a trabalho despendido visando atingir o objetivo da sociedade.

Lembra ainda o autor que na societas, aparece o conceito de arca communis, onde seriam depositados os créditos disponíveis. Em proporção aos interesses individuais na sociedade, cada sócio teria uma parte dos créditos ali depositados, não sendo esses considerados como ativos em casos de falência da sociedade.

No entanto, o empreendimento mais desenvolvido pelos romanos foi o peculium. Ali os romanos incluíam seus filhos e seus escravos. E os escravos, se obtivessem sucesso, poderiam conquistar a sua liberdade. A responsabilidade era limitada ao valor do peculium e aos lucros obtidos, entretanto, os credores estavam autorizados a acionar o proprietário do escravo se este viesse a exercer o controle direto do pecúlio. Os credores do proprietário do escravo tinham direito a todos os bens dele, inclusive os atribuídos ao peculium ${ }^{8}$.

Uma forma aparente de sociedade com algum tipo de proteção do seu patrimônio contra os credores dos seus sócios, a societas publicanorum era um tipo societário com vários proprietários, conforme nos dão conta HANSMMAN et alli. Já no século IV a.C. ela consistia num grupo de investidores, os publicani, que investiam em contratos estatais como aqueles para a construção de obras públicas, provisão de armamentos e coleta de impostos ${ }^{9}$.

A estrutura da societas, segundo Rui Manuel Figueiredo MARCOS compreendia as seguintes figuras: o manceps, que era um sócio que participava das licitationes públicas e era aquele a quem era formalmente adjudicado o arrendamento do imposto. Aos magistri e aos promagistri era entregue a administração da sociedade. A representação da sociedade em juízo era feita pelo actor (ou sindicus). Aqueles que participavam da sociedade apenas com os aportes que faziam eram chamados de socii. Havia ainda os adfines que tinham participações nos lucros, mas não na gestão dos negócios ${ }^{10}$.

Os publicani usavam suas terras como garantia e dividiam-se em dois grupos, aqueles que assumiam o controle do empreendimento e, portanto, a

\footnotetext{
${ }^{8}$ In HANSMANN, KRAAKMAN e SQUIRE, ob. cit., p. 19.

${ }^{9}$ In ob. cit., p. 20; vide SALOMÃO FILHO, Calixto. "Societas" com relevância externa e personalidade jurídica in Revista de Direito Mercantil, Industrial, Econômico e Financeiro. São Paulo, no 81, pp. 66/78, jan./mar. 1991.

${ }_{10}^{10}$ In As companhias pombalinas - contributo para a história das sociedades por acções em Portugal. Coimbra: Almedina, 1997, p.18.
} 
responsabilidade pelos negócios, e aqueles que não exerciam controle algum, eximindo-se de qualquer responsabilidade.

Nessa entidade (societas) diferentemente do que acontecia no peculium, havia proteção do patrimônio social contra os credores dos proprietários. E as razões para isso são várias, menciona-se, por exemplo, que os custos para a constituição de uma empresa de grande porte eram muito altos e que só valia a pena nos investimentos em que fosse grande o número de investidores, o que não ocorria no peculium, e só tinha sentido para os grandes empreendimentos que exigiam grande aporte de capital.

HANSMMAN et alli ponderam, ainda, que o peculium, por ser uma entidade com um único proprietário, caso tivesse o benefício de proteção contra os credores do seu dono, poderia ser objeto de fraude contra credores, ou seja, poderia servir como forma do devedor colocar ali grande parte dos bens que possuía com fins de frustrar a cobrança dos seus débitos.

MARCOS ainda comenta sobre tais entidades:

"Já, a propósito das societates publicanorum, ergueram-se várias teses contrastantes, mesmo à luz dos textos. Uma defendia, em atenção à natureza excepcional de tais entes, a alienabilidade das participações dos sócios. Outra sustentava apenas o carácter transmissível dos arrendamentos. Uma outra insistia que a hipótese de transferência se tinha de restringir às partes dos adfines. Outra ainda acrescentava que as cessões se deviam considerar à margem do contrato e das relações entre os sócios. Ainda outra pronunciava-se pela clara exclusão dos mancipes desse jogo face ao interesse do Estado na pessoa dos adjuticatários e duvidava também que os publicanos admitissem as constantes mudanças das personagens a eles associadas."

Mas o desenvolvimento da societas publicanorum é impedido com a chegada do Império. Ela teve seu tempo durante a República, mas a riqueza e a influência dos publicani não resistiram à inveja dos imperadores que então fizeram o Estado reassumir o controle dos grandes empreendimentos, relegando aos publicani a função de coleta de impostos, mas já no século II d.C. eles não mais exerciam tal função ${ }^{12}$.

\footnotetext{
${ }^{11}$ In ob. cit., p. 20.

${ }^{12}$ MARCOS, ob. cit., pp. 24/25.
} 
Após a queda do Império Romano, a ausência de autoridade obrigou os particulares a construírem, de alguma forma, a sua própria proteção jurídica. Por essa razão, já na Idade Média, encontram-se termos indicando a união de forças individuais para consecução de objetivos comuns. Objetivos esses não necessariamente ligados a interesses econômicos (fraternitas, consortium, communitas, collegantia).

Para alguns reside na Idade Média, por volta do século XII, o germe das sociedades anônimas enquanto outros entendem que os movimentos ou formas de associação havidos na Idade Média foram fenômenos isolados, que se fizeram sentir em várias partes, em razão das exigências econômicas da época ${ }^{13}$. Mais especificamente na exploração de moinhos. SICARD nos dá notícia dos moinhos de Toulouse que funcionavam segundo concessão outorgada por um senhor feudal ou pela própria Igreja a uma sociedade, a cujo membro se dava o nome de pairier e que, pelo menos em uma fase inicial, tinha o status de co-proprietário ${ }^{14}$.

Cada moinho era dividido em cotas ideais, chamadas saches ou uchaux, que indicavam a participação de cada sócio nos encargos e nos lucros. Tais partes eram livremente transmissíveis, nas formas da cessão imobiliária ${ }^{15}$.

Segundo SICARD, foi na segunda metade do século XIV que se começou a propugnar pela limitação da responsabilidade dos sócios, ao montante correspondente às frações ideais, como se fosse uma pessoa jurídica distinta, com patrimônio próprio ${ }^{16}$.

MARCOS afirma que também no âmbito da extração mineira, na Itália e na Alemanha, fala-se em antecedentes das sociedades por ações. Na Alemanha a copropriedade de minas, cujo direito se expressava em títulos denominados kuxen, transmissíveis e divisíveis, servindo mesmo como garantia hipotecária foi que deu base ao instituto. O direito ao lucro era considerado um bem móvel, sendo também calculado em função da propriedade dos títulos e os sócios eram obrigados ao pagamento das dívidas sociais, mas podiam retirar-se das sociedades abandonando o quinhão ${ }^{17}$.

$\mathrm{O}$ mesmo autor ainda afirma que a indústria metalúrgica do século $\mathrm{XV}$ também é apontada como nascedouro das sociedades anônimas. Fala-nos sobre uma que

\footnotetext{
${ }^{13}$ Ver nesse sentido MARCOS, ob. cit., p. 34; HILAIRE, Jean. Introduction historique au droit commercial. Paris: Presses Universitires de France 1986, p. 183; SICARD, Germain. Aux origines des sociétés anonymes. Les moulins de Toulouse au moyen age. Paris: Librarie Armand Colin, 1953, p. 172.

${ }^{14}$ In ob. cit., pp. 73,149 e ss. e 178 .

${ }^{15}$ SICARD, ob. cit., pp. 237/238.

${ }^{16}$ Idem, p. 306.

${ }^{17}$ In ob. cit., pp. $24 / 25$.
} 
teve lugar na cidade de Leoben nos idos de 1415, que se dedicava ao comércio e à metalurgia do ferro.

As sociedades de pessoas surgiam num ambiente feudal em que ainda prevaleciam as corporações de ofício (contrárias a esse regime) e as religiosas. De sorte que as normas que disciplinavam o comércio eram oriundas das regras dos mercados, elaboradas a partir de práticas e preceitos costumeiros aos quais se submetiam os mercadores $^{18}$.

Curiosamente, muitos institutos foram desenvolvidos para o comércio marítimo e depois aplicados para as relações terrestres. Dentre tais institutos a própria limitação da responsabilidade.

Somente no período que cobre os séculos XI a XIII, época em que cessaram as invasões bárbaras e vislumbrou-se relativa paz, o comércio encontrou seu período de maior desenvolvimento, com a passagem de uma economia fechada nos feudos para uma abertura comercial no Mediterrâneo, sendo o crescimento das cidades, segundo LE GOFF $^{19}$, fundamental para a chamada revolução comercial. As cidades serviam de abrigo aos mercadores errantes e as mais bem localizadas se transformaram em importantes locais de trânsito de mercadorias ${ }^{20}$.

A evolução do comércio, o desenvolvimento dos contratos mercantis e o aperfeiçoamento dos meios de transporte, fruto das invenções da bússola e da vela latina bem como do desenvolvimento da cartografia, são marcos desse momento histórico e foi nessa época que surgiu a sociedade em nome coletivo.

SANTARELLI ${ }^{21}$ anota a importância da família constituída em torno da figura do pater, entendida como pai, irmãos, filhos de qualquer natureza, irmãs, mãe, mulher e noras no Statuto Del Popolo di Bologna, de 1287, e, dada a necessidade de capitais, a necessidade de manter-se unido o patrimônio familiar. Destaca, ainda, o significado da palavra "casa" como habitação da família e sede da empresa comercial.

Cabe, nesse ínterim, pequena digressão a respeito do fenômeno associativo identificado nas hansas (associações que existiam em várias cidades do norte da Europa, na

\footnotetext{
${ }^{18}$ LAMY FILHO e PEDREIRA chamam tais normas de 'jus mercah' e de 'ius comercium' os costumes que as originaram, cf., ob. cit., p. 26.

${ }^{19}$ LE GOFF, Jacques. Marchands et banquiers du moyen âge. $9^{a}$ ed. Paris: Press Universitaires de France, 2006, p. 10.

${ }^{20}$ PIRENNE, Henri. História econômica e social da idade média, trad. port. Lycurgo Gomes da Motta. $4^{\mathrm{a}}$ ed. São Paulo: Mestre Jou, 1968, pp.47/48.

${ }^{21}$ SANTARELLI, Umberto. Mercanti e società tra mercanti. $2^{\mathrm{a}}$ ed. Turim: G.Giappichelli Editore, 1992, pp. $123 / 128$
} 
Idade Média, para efeitos comerciais) e nas guildas (associações de auxílio mútuo constituídas na Idade Média entre as corporações de operários, artesãos ou negociantes).

Consoante HEILBRONER ${ }^{22}$, as guildas eram as "unidades de negócios" da Idade Média composta por mestres, jornaleiros, pagos por dia, e aprendizes ligados a eles por um período de 3 a 12 anos como tutelados legais e ninguém podia estabelecer-se sem pertencer a uma.

As hansas e as guildas mercantis foram associações que se constituíram ao longo do século XII, primordialmente ligadas ao comércio interno e posteriormente ao externo, formadas por mercadores que frequentavam as mesmas praças de negociação e que decidiram se unir.

Como bem pondera MARCOS, as guildas surgiram como forma de auxílio mútuo entre os participantes, sendo que estes realizavam seus negócios por sua conta e risco, o que, é bom que se diga, não impedia o surgimento de sociedades entre mercadores no interior da organização ${ }^{23}$.

Dentre as hansas convém destacar a Hansa Teutônica formada por mercadores e cidades que circundavam o mar Báltico no século XII, com centro na ilha de Gotland. MARCOS explica que a instituição fazia menção tanto aos indivíduos que compunham a organização quanto aos direitos dos quais se beneficiavam, mas que sempre se propugnou pela independência dos participantes, mantendo cada um os negócios próprios e clientes ${ }^{24}$. Já a sociedade em comandita simples teve provável origem no contrato de commenda. No entanto, em ambas continuava a ser o comerciante o protagonista da atividade mercantil.

De grande importância se revestiram também as feiras da época (século XIII) que se realizavam, em geral, uma vez por ano, principalmente em diversas cidades da região de Champagne ${ }^{25}$, com duração de 49 dias, e que foram regulares e destacados centros bancários. Este comércio itinerante dos mercadores chamados "pés poeirentos" (pieds poudreux ou pie-powers), cuja existência remonta ao século IX, veio a declinar com o surgimento do mercador estabelecido nas cidades no decorrer do século $\mathrm{XV}$, com o

\footnotetext{
${ }^{22}$ HEILBRONER, Robert L. The making of economic society. New Jersey: Prentice-Hall, 1962, p. 36.

${ }^{23}$ In ob. cit., p. 41.

${ }^{24}$ In ob. cit., pp. $41 / 42$.

${ }^{25}$ Lagny (janeiro-fevereiro), Bar (março-abril), Provins (maio-junho e setembro-novembro), Troyes (julhoagosto e novembro-dezembro) cf. LE GOFF ob. cit., p.16.
} 
estado de guerra em França ${ }^{26}$ e com o incremento do intercâmbio marítimo entre a região do Mediterrâneo e a Europa do Norte.

Surgem, nesse período, institutos que podem ser enquadrados como precedentes históricos das sociedades por ações. Dentre estes, lembra-se das maone, empréstimos alienáveis e transmissíveis concedidos pelos governos das cidades-estado da Itália; e das rheederein, associações constituídas para a armação de navios, que emitiam títulos de participação também transmissíveis e alienáveis, que garantiam a limitação da responsabilidade dos associados. MARCOS anota que, no caso dessas entidades, a embarcação era cindida em partes transmissíveis e os seus proprietários respondiam pelas dívidas contraídas somente até o valor da embarcação somado com o da carga ${ }^{27}$.

Com efeito, não é certo que tais institutos se configurem em originários das sociedades anônimas uma vez que as maone não possuíam caráter especulativo, no sentido de participação nos riscos e nos ganhos, já que interessava aos investidores apenas uma quantia módica de retorno, quando não estavam revestidas de caráter cívico de investimento em empreendimentos de interesse geral; já a limitação da responsabilidade nas rheederein não poderia ser estendida a outras atividades ${ }^{28}$. GARRIGUES ${ }^{29}$ entende que das sociedades navais (Reedereien ${ }^{30}$ ) nasceram as grandes companhias coloniais, que constituiriam o antecedente mais direto da moderna sociedade por ações.

As corporações eclesiásticas medievais, por sua vez, também devem ser lembradas como importante precedente histórico das sociedades anônimas pela contribuição que deram para a cristalização da idéia da personalidade jurídica.

O raciocínio estava em que os mosteiros eram entendidos como propriedade de Deus, revezando os seus membros, mas nunca seu titular, e, conforme LAMY FILHOe PEDREIRA, "formou-se a convicção da existência de um corpus mysticus, que sobrepairava aos seus membros" 31 . Por essa razão, para o Direito Canônico, a concessão da personalidade jurídica era um privilégio que dependia de um ato da Igreja.

\footnotetext{
${ }^{26}$ A chamada Guerra dos Cem Anos foi travada entre a França e a Inglaterra de 1337 a 1453.

${ }^{27}$ In ob. cit., pp. $26 / 29$.

28 BULGARELLI é categórico em afirmar que tanto as maone quanto as rheederein não podem ser compreendidas como precedentes das companhias: "Também não se confundem com os dois tipos medievais denominados Montes e Maone italianos, nem com o reederei, organização naval germânica constituída para financiar empresas militares e econômicas do Estado, atraindo a poupança privada", in Manual das sociedades anônimas. $12^{\mathrm{a}}$ ed. São Paulo: Atlas, 1997, p. 61.

${ }^{29}$ In Curso de derecho mercantil, $7^{\mathrm{a}}$ ed. Bogotá: Temis, 1987, p. 106.

${ }^{30}$ Os autores divergem quanto à grafia do termo.

${ }^{31}$ Cf. LAMY FILHO e PEDREIRA, ob. cit., p. 30.
} 
Já como recurso à crise financeira por que passavam as comunas italianas nos séculos XII e XIII, as cidades promoveram uma onda de empréstimos, quase sempre forçados, cuja garantia consistia na outorga da cobrança de determinadas receitas públicas. O montante da operação era repartido em partes iguais e transferíveis, denominadas luoghi ou loca e, sobre a descrição da natureza da loca, interessante o comentário de MARCOS:

"De início, proporcionaram uma quantia fixa e, a partir de 1418, ofereceram réditos variáveis. Achavam-se registrados nos livros sociais (cartulari) e, em caso de alienação, eram transcritos em nome dos adquirentes. Determinados insequestráveis por norma, resta acrescentar que sofriam oscilações de preços.",32

A despeito disso, certa controvérsia cobre a formação das sociedades anônimas. Em verdade, há autores, e não são poucos, que defendem que o real precedente desta instituição foi o Banco de São Jorge. No que tange ao Banco, cabem aqui algumas linhas sobre a sua formação.

Conforme a dicção de PIRENNE ${ }^{33}$, as cidades italianas no século XII concediam a cobrança de parte de sua receita a seus credores, até o pagamento da dívida, e, em 1164, a cidade de Gênova cedeu por onze anos parte de suas rendas a uma sociedade de sete pessoas (Monte), tendo consolidado sua dívida no século XIII e reconhecido o direito de seus credores venderem seus títulos a terceiros, dando esta como origem da Casa di San Giorgio, fundada em 1407.

No início do século $\mathrm{XV}$, seguindo a tendência da criação de associações de classe, os credores da cidade de Gênova se reuniram em uma única entidade, com o escopo de orientar todo o regramento da dívida pública. Nascia ali a Casa de San Giorgio, ou Banco de São Jorge, e assim nos conta Hilaire:

\section{“Au début du XV siècle, 'compere' et 'maones' génoises furent réunies em um seul organisme, la 'Casa di San Giorgio' ayant la charge de gérer toute la dette publique et qui reçut l'autorisation de faire des opérations bancaires." 34 .}

\footnotetext{
${ }^{32}$ In ob. cit., p. 31.

${ }^{33}$ In ob. cit., p.144.

34 “Ao alvorecer do século XV, 'compere' e maones' foram reunidas em um só organismo, a 'Casa di San Giorgio' tendo o encargo de gerir toda a dívida pública e que recebeu a autorização de realizar operações bancárias" (trad. livre) in ob. cit., pp. 183/184.
} 
GARRIGUES descreve a instituição financeira da seguinte maneira:

"Espíritu de lucro y carácter corporativo de la asociación, que al princípio faltaban, se perciben ya claramente a princípios del siglo $X V$, cuand la Casa di S. Giorgio se transforma em Banco di S. Giogio por haber asumido actvidades bancarias lucrativas (1407). A imitacíon del Banco di S. Giorgio nació en Milán el Banco de S. Ambrogio em el año 1592 y se transformó en banco por acciones el año 1598." "35.

Nesse sentido BULGARELLI ${ }^{36}$ é assente em afirmar que a primeira organização a apresentar os elementos principais das sociedades por ações foi o Banco de São Jorge. VALVERDE também segue no mesmo sentido:

"As investigações históricas não conseguiram, definitiva $e$ uniformemente, localizar sua origem. Mas é opinião geral que o Banco de São Jorge, constituído em Gênova no ano de 1407, foi a organização que, pela primeira vez corporificou os elementos principais do instituto, ${ }^{, 37}$

O modelo de sociedade por ações foi utilizado também em outros empreendimentos de pequena monta, sempre dependentes da concessão do Estado, e o fato de serem poucos não impediu a formação de um mercado de valores mobiliários.

Com efeito, em relação à atividade bancária italiana referente ao período Quattrocento, COMPARATO ${ }^{38}$ divide as atividades em quatro, seguindo a classificação de Raymond DE ROOVER ${ }^{39}$, a saber:

(i) banchi de pegno: casas de penhor, que emprestavam em curto prazo com garantia pignoratícia. Para operar, a casa necessitava de autorização pública, dada a proibição canônica da usura contra operações de crédito de consumo (atividade principal de tais bancos). As autorizações em questão, até meados do século XV, eram concedidas unicamente aos judeus.

\footnotetext{
${ }^{35}$ In ob. cit., p. 106.

36 “A maioria da doutrina propende, no entanto, por reconhecer que a primeira organização a apresentar os elementos principais das sociedades por ações foi o Banco de São Jorge, fundado em Gênova, em 1407, corporação formada pelos credores da República Genovesa, que transformaram seus títulos de renda em ações nominativas do banco estatal, e que eram inscritas num registro e negociadas livremente no mercado, de acordo com suas cotações" in ob. cit., p. 61.

${ }^{37}$ VALVERDE, Trajano de Miranda. Sociedades por ações (comentários ao decreto-lei $n^{o} 2627$, de 26 de Setembro de 1940), vol. I. $3^{\text {a }}$ ed. Rio de Janeiro: Forense, 1959, p. 1.

${ }^{38}$ In Direito empresarial: estudos e pareceres. São Paulo: Saraiva, 1995, pp. 262/263.

${ }^{39}$ DE ROOVER, Raymond. The Medici bank: its organization, management, operations, and decline. New York: New York University Press, 1948, pp. 1/4.
} 
(ii) banchi a minuto: ligados à ourivesaria e ao comércio de metais e pedras preciosas. Porém, também recebiam depósitos em dinheiro, unicamente a prazo fixo, vencendo juros.

(iii) banchi in mercato: sua denominação deriva do fato de as operações, majoritariamente de câmbio, serem feitas nas praças do Mercato Nuovo e do Mercato Vecchio.

(iv) banchi grossi: operavam em ambiente fechado, fazendo câmbio e negociando mercadorias nas principais praças do Ocidente e do Oriente.

Um exemplo do último tipo, banchi grossi, é o Banco Medici de Florença ${ }^{40}$. Suas atividades englobavam, ainda, a exploração de jazidas de alume e o recolhimento das dízimas pontifícias, mantendo-as em caixa por um longo período de tempo, em troca da cooperação com a Igreja em relação a pedidos de adiantamentos.

A atividade dos Médici distingue-se dos outros bancos florentinos (como os Peruzzi, Acciaiuoli e Bardi) pela estrutura empresarial hábil e flexível que permitiu a criação de um regime altamente internacionalizado, com a substituição de agências nos estrangeiros por sociedades locais, e perpetuasse a inovação criada pelos banqueiros florentinos de distinção do sócio controlador em relação aos demais.

Dessa forma, estabeleceram-se explorações locais através de sociedades autônomas, evitando-se os perigos de uma organização societária não-fragmentada (como a falência dos Bardi, em 1345) ${ }^{41}$. Nesse contexto, a sociedade matriz funcionava como holding, estando, de um lado do contrato de constituição de uma subsidiária os representantes da Casa dos Médici e do outro os sócios que participariam da sociedade ${ }^{42}$.

Outro fato importante em relação ao conglomerado Médici diz respeito à forma como a família mantinha sempre o controle da sociedade objetivando, principalmente, manter o poder de dissolver a sociedade a qualquer momento, estipulando diretrizes a serem observadas quando da dissolução, tais como a eleição de foro para tais casos.

\footnotetext{
${ }^{40}$ Embora existam dúvidas entre alguns autores sobre a verdadeira denominação que deve ser usada em relação à Casa Médici, precisa é a opinião de COMPARATO, afirmando que qualquer dúvida a respeito se deve a uma compreensão superficial da realidade empresarial da época. Em seu entender, a Casa Médici era um banco, seja pela sua denominação, seja pela sua atividade, in ob. cit., p. 262.

${ }^{41}$ Cf. COMPARATO, ob. cit., p.264.

${ }^{42}$ Ao lado da casa matriz em Florença, existiam, no século XV, filiais em Londres, Bruges, Genebra, Lyon, Avignon, Milão, Veneza e Roma cf. LE GOFF, ob. cit., p.22.
} 
Destaque-se, também, a evolução gradativa do sistema de escrituração por partidas dobradas que começaram a surgir nos séculos XIII e XIV no norte da Itália ${ }^{43}$, codificado pelo frei franciscano Luca Pacioli (1445-1517) em seu livro Summa de Arithmetica, Geometria, Proportioni et Proportionalita, de 1494, em especial no capítulo Particularis de Computis et Scripturis, dando publicidade ao chamado método de Veneza e levando à unificação dos procedimentos de escrituração.

Anteriormente a Pacioli, a publicação de Leonardo Fibonacci ${ }^{44}$, Líber Abaci, de 1202, é considerado o início da contabilidade moderna enquanto o livro $L a$ Pratica della Mercatura, de 1340, escrito por Francesco di Balduccio Pegolotti, era o manual do comerciante de então ${ }^{45}$.

Existiam diversos livros do comerciante como das sucursais, das compras e das vendas e, também, o chamado livro secreto que consigna o texto da associação, a participação dos associados no capital ${ }^{46}$.

As sociedades eram criaturas do direito público e reflexo das exigências do mercantilismo da época. Tratava-se de um organismo revestido de poderes governamentais e privilégios de negócios, embora apresentasse uma organização societária incipiente ${ }^{47}$.

Entretanto, não haveria desenvolvimento econômico sem o instituto da bolsa. Este era o local em que, já na Idade Média, investidores e intermediários se encontravam para realizar negócios, embora tenha sido o espírito especulativo que veio a criar as bolsas especializadas em valores mobiliários. Nessa época, as ações tinham forma nominativa como recurso para se fugir da especulação, o que não necessariamente surtia muito efeito uma vez que o título não era exigido para a negociação.

Foram os descobrimentos que fizeram com que as nações européias e os comerciantes se associassem para enfrentar os desafios econômicos e políticos. $\mathrm{O}$ desenvolvimento cultural, político e econômico da Europa, nos séculos XV e XVI, a

${ }^{43}$ HENDRIKSEN, Eldon S. e VAN BREDA, Michael F. Teoria da contabilidade. trad. port. Antonio Zoratto Sanvicente. São Paulo: Atlas, 1999, p. 39.

${ }^{44}$ Nascido em Pisa por volta de 1180 é mais conhecido pelos números de Fibonacci $(1,1,2,3,5,8,13,21, \ldots)$ com aplicação na matemática e na arte.

${ }^{45}$ CARDOSO, Ana Paula e RODANTE, Antonio coord. ed. Auditoria: registros de uma profissão. São Paulo: IBRACON - Instituto dos Auditores Independentes do Brasil, 2007, p. 20/27. No Brasil, o método das partidas dobradas foi formalizado na Real Fazenda por Alvará de 28 de junho de 1808, ainda que tal método já fosse utilizado à época da Inconfidência Mineira (p. 48).

${ }^{46}$ LE GOFF, in ob. cit., pp. 32/33.

${ }^{47}$ Nesse sentido, BULHÕES e LAMY: "Observe-se, desde logo, a inexistência de uma vida financeira definida, pois as noções de capital social como prestação irrevogável, de lucro líquido, de dividendo periódico, e mesmo de balanços, existiam, apenas, em gérmen, e de forma imprecisa. Ademais, os direitos da minoria apenas nas sociedades inglesas eram resguardados, com o instituto do 'trust'; as demais sociedades eram dominadas pelos grandes sócios ... e o princípio de 'a cada ação um voto' ainda não se difundira... [e] a administração era oligárquica, sempre dominada pelo mesmo grupo", in ob. cit., p. 42. 
transição da Idade Média para a Idade Moderna, a Reforma Religiosa e a Renascença, iniciaram o processo de formação das economias de mercado ${ }^{48}$. Entretanto, a sua maturação só teve início com a Revolução Industrial do século $\mathrm{XIX}^{49}$.

A pequenez do sistema fabril, tanto estrutural quanto do sistema de produção, não exigia mais que os grupos familiares para a produção agrícola e a sociedade em comandita simples e em nome coletivo, para as entidades coletivas em geral.

Em verdade, os descobrimentos criaram a necessidade de produção em escala superior aos níveis então conhecidos, devido às possibilidades de lucro extenso e às grandes somas de capitais necessários para os investimentos. É nesse contexto que surgem as companhias colonizadoras.

GALGANO afirma que as Companhias das Índias dos séculos XVII e XVIII são as primeiras grandes companhias da era moderna, o verdadeiro precedente da sociedade anônima. Segundo o autor, é aí que aparecem, pela primeira vez, tanto a limitação da responsabilidade estendida a todos os sócios, quanto a divisão do capital social em ações ${ }^{50}$, afirmativa que confirma em obra posterior" ${ }^{51}$ tratando de "socialização “ do capital e "democracia econômica".

GARRIGUES comenta que tais companhias foram criadas pelo Estado seguindo o sistema do octroi, isto é, um ato de incorporação e de concessão de direitos que permitia ao ente soberano o controle da companhia, pela intervenção constante no seu cotidiano, em respaldo à concessão de determinados privilégios à entidade ${ }^{52}$.

BULGARELLI, nesse mesmo sentido, entende que o Estado, por meio do sistema de octroi, conferia às companhias personalidade jurídica e patrimônio autônomo. Afirma, ainda, que as sociedades por ações passam, em relação à constituição, por três sistemas diversos: o octroi, a autorização e a regulamentação ${ }^{53}$.

A primeira companhia privilegiada foi a Companhia Inglesa das Índias Orientais (Company of Merchants of London Trading to the East Indies), posteriormente

${ }^{48}$ Cf. R. C. VAN CAENEGEM, Uma introdução histórica ao direito privado. $2^{\mathrm{a}}$ ed., trad. port. Carlos Eduardo Lima Machado. São Paulo: Martins Fontes, 2000, p. 44.

${ }^{49}$ Adicione-se a estes, outros fatores: a dissolução das principais instituições econômicas da Idade Média; o aumento da população, e o consequente aumento da demanda por alimentos e outros bens; a mudança dos principais centros comerciais e financeiros (Itália para Holanda); expansão industrial do século XV (tecidos, metais, couros, cerveja e vinho) surgida da acumulação de capital dos comerciantes, nobres e senhores feudais, embora ainda incipiente no que tange à dimensão das unidades fabris e ao sistema de produção ainda doméstico.

${ }^{50}$ In História do direito comercial, trad. port. João do Espírito Santo. Lisboa: Editores, 1990, pp. 66/67.

${ }^{51}$ In Lex mercatoria. Bolonha: Il Mulino, 2001, pp.141/178.

${ }^{52}$ In ob. cit., p. 108.

${ }^{53}$ Idem, pp. 60/61. 
denominada Companhia Britânica das Índias Orientais, tendo a Rainha Elizabeth $\mathrm{I}^{54}$ concedido em 1599, segundo VALVERDE, o "direito exclusivo de entrar em relações comerciais com as Índias Orientais e demais países a leste do cabo da Boa Esperança e ao ocidente do estreito de Magalhães." 55 .

Outra importante Companhia Colonizadora foi a das Índias Orientais, fundada na Holanda em 20 de março de 1602, seguida da Companhia das Índias Ocidentais de 3 de junho de $1621^{56}$. A primeira foi constituída com a união de oito rheederein, embora tenha sido admitida a contribuição de todos que quiseram fazê-lo. A cada contribuinte outorgava-se um título de participação que lhes assegurava o direito de ação contra a companhia, daí o termo "ação" (Aktie), nome do título de participação.

A administração das companhias holandesas era oligárquica, sendo o órgão principal da primeira conhecido como os Dezessete Senhores (Heeren Serventin) e da segunda o Conselho dos Dezenove. Dessa forma, os sócios tinham pouca ou nenhuma influência no comando desta, embora isso fosse compensado com a facilidade de negociação das ações. Ainda assim, em 1621, quando da fundação da Companhia das Índias Ocidentais, foi também criado um conselho fiscal e em 21 de junho de 1623 foi deliberado que as contas seriam elaboradas em estilo comercial.

Embora a vida financeira não fosse bem regulamentada, os investidores, de início, tinham participações a cada viagem por liquidação, sendo posteriormente transformadas em participações permanentes. Já se encontrava ali o precedente do capital social, o fundo perpétuo, instrumento de verificação dos ganhos líquidos a que teriam direito dos membros, sendo estes ainda isentos pelo estatuto de responsabilidade pelas obrigações da empresa, exceto em caso de decisão contrária dos Tribunais da época.

FERREIRA destaca o princípio da limitação da responsabilidade como facilitador da transmissibilidade das ações que eram negociadas na Bolsa de Amsterdã e classifica as companhias holandesas como sociedades de economia mista, em contraste com a Companhia Geral do Comércio do Brasil ou Junta do Comércio, criada em Portugal por alvará real de 10 de março de 1649, dada como companhia privada. Nesta a transferência das quotas sociais se dava de forma particular, caracterizando-se, segundo o autor, como sociedade de comanditários e não de acionistas ${ }^{57}$.

\footnotetext{
${ }^{54}$ Reinou de $17 / 11 / 1558$ a 24/03/1603.

${ }^{55}$ In ob.cit., p. 41.

${ }^{56}$ FERREIRA, Waldemar. O direito público colonial do Estado do Brasil sob o signo pombalino. Rio de Janeiro: Nacional de Direito, 1960, pp. 38/46.

${ }^{57}$ In ob. cit., p. 48.
} 
Já VALVERDE ${ }^{58}$ entende que aí surgem claramente as ações em que "Os cabedais constantes das 'cartas' se transformam em valores mobiliários circulantes no mercado". MARCOS ${ }^{59}$, por seu turno, destaca o Regimento de 27 de agosto de 1628 que o $\operatorname{Rei}^{60}$ outorgou à Companhia da Índia Oriental como o primeiro estatuto completo de uma companhia portuguesa. Tal estatuto trazia um esboço de separação de patrimônio da sociedade e do sócio, então chamado companheiro, participante ou partícipe, destacando-se o princípio da permanência do fundo social ao não ser permitida a retirada dos recursos aportados por doze anos, ainda que se permitisse a transferência nos livros da Companhia.

No direito português a primeira referência normativa ao contrato da sociedade ou companhia é encontrada nas Ordenações Filipinas, de $1603^{61}$, em seu Livro 4, título 44, cuja aplicação no direito pátrio foi revogada somente com o Código Civil de $1916^{62}$. Era estabelecida a regra de limitação de responsabilidade, no item $10^{63}$, ainda que houvesse controvérsia a respeito de ser solidária ou não.

As companhias inglesas, por sua vez, tinham certas peculiaridades que as diferenciavam das demais do continente europeu. Falava-se nas regulated companies, instituições que não tinham o comércio como atividade precípua, mas sim sua regulação. Tais companhias eram mais assemelhadas a órgãos públicos com função de regular o comércio exterior, de participação exclusiva dos comerciantes e aristocratas e que já gozavam de personalidade jurídica. Nelas os sócios tinham participação (a cada pessoa um voto na Assembléia Geral) e os administradores, agindo como trustees ${ }^{64}$ dos sócios, tinham de respeitar o interesse da companhia.

Em França, ao tempo de Richelieu, primeiro-ministro de Luís XIII de 1628 a 1642, e de Colbert, ministro de Luís XIV, existem traços das sociedades anônimas nas companhias privilegiadas (compagnies à charte), com destaque para as Companhias das Índias Ocidentais e Orientais de 1644.

\footnotetext{
${ }^{58}$ In ob. cit., p. 15.

${ }^{59}$ In ob. cit., pp. 132/150

${ }^{60}$ Filipe IV foi Rei da Espanha entre 1621 e 1665 e Rei de Portugal como Filipe III de 1621 a 1640, quando ocorreu a restauração da independência portuguesa com a assunção da Casa de Bragança.

${ }^{61}$ Publicada sob o reinado de Filipe II de Portugal (1598-1621), também Filipe III de Espanha.

62 "Art. 1.807. Ficam revogadas as Ordenações, Alvarás, Leis, Decretos, Resoluções, Usos e Costumes concernentes às matérias de direito civil reguladas neste Código."

63 "As dividas, que se fizerem por respeito da Companhia e sociedade, della mesma se hão de pagar, postoque a esse tempo seja já acabada.

E da mesma maneira se ha de tirar da Companhia a perda e dano, que houve nas cousas della, ou que aconteceu a qualquer dos companheiros, nas suas cousas próprias por causa da tal Companhia.

Assi como, se sendo mandado hum delles a certo negocio tocante a Companhia, o roubarem os ladrões no caminho, em que for, ou o scravo que levar."

${ }^{64}$ Trustee aqui entendido, com fundamento na doutrina estadunidense, como administradores com liberdade de ação, devendo agir em consonância com suas prerrogativas, lealdade e cuidado.
} 
$\mathrm{Na}$ época assiste-se a um esforço de codificação e, dentre outras ordenações, são editados o Ordennance sur le commerce, de 1673, e o Code de la marine, de 1681, inspiradoras do Código comercial francês do início do século XIX.

Já nos idos de 1720, John Law constrói o Banco Real que viria a se tornar o maior escândalo financeiro do país, arruinando diversos investidores e desacreditando o mercado de ações daquele país ${ }^{65}$.

$\mathrm{Na}$ mesma época, na Inglaterra, grandiosos esquemas especulativos criaram um fenômeno que ficou conhecido como bubble mania, em razão de as companhias que emitiam ações serem tão vazias como uma bolha de ar, no que respeita à substância econômica. É por essa razão que o Bubble Act, em julho de 1720, veio a proibir o ato de agir como pessoa jurídica, ou fingir presumir que agia, para colocar ações na bolsa sem prévia autorização do Parlamento, levando os investidores ao pânico e a South Sea Company ${ }^{66}$ à bancarrota ${ }^{67}$.

Em Portugal, D. José I ${ }^{68}$, por sugestão de Sebastião José de Carvalho e Melo $^{69}$, Secretário de Estado, consentiu, por alvará real de 7 de julho de 1755, a constituição da Companhia Geral do Grão Pará e Maranhão solicitada por homens de negócio da praça de Lisboa, sendo o monopólio de navegação, comércio e tráfico de escravos destinados ao Maranhão e Pará fixado em vinte anos de duração, a contar da data da largada da primeira frota, o que ocorreu em $1758^{70}$.

Segundo FERREIRA ${ }^{71}$ a Companhia do Grão Pará se apresentou como companhia por ações, diversamente da Companhia Geral para o Estado do Brasil, ainda que não se possa chamá-la de sociedade anônima, havendo duas categorias de acionistas: os ostensivos (subscritores até 10 ações) e os ocultos (subscritores de mais de 10 ações).

\footnotetext{
${ }^{65}$ Antoin E. MURPHY nos dá notícia de que a proeza de Law esteve em convencer os franceses a converter toda a sua atividade financeira à simples escolha entre ações ou papel moeda. E o sucesso do seu sistema foi tão grande que a Inglaterra, então vencedora da guerra sucessória pelo trono da Espanha, precisamente contra a França, decidiu imitar o sistema de Law, para não ficar para trás no desenvolvimento macroeconômico. E embora não houvesse nada de original no projeto de Law, a sua genialidade fez a França, pelo menos aparentemente, superar a crise monetária e financeira pela qual passava. In "John Law: innovating theorist and policymaker". The origins of value: the financial innovations that created modern capital markets. Oxford: Oxford Press, 2005, p. 226.

${ }^{66}$ Daí a crise de 1720 na Inglaterra ter ficado conhecida como a Bolha dos Mares do Sul.

${ }^{67}$ Para uma interessante descrição do fenômeno ver MACKAY, Charles. Extraordinary popular delusions and the madness of crowds (1841). New York: John Wiley \& Sons, 1996.

${ }^{68}$ Reinou no período de 1750 a 1777.

${ }^{69}$ Mais conhecido como Conde de Oeiras ou Marquês de Pombal.

${ }^{70}$ Ver CARREIRA, António. A Companhia Geral do Grão-Pará e Maranhão. São Paulo: Editora Nacional, 1988 , p. 66.

${ }^{71}$ In ob. cit., p. 141.
} 
Na sombra de seu inicial sucesso, foi concedido o alvará real para a Companhia Geral de Pernambuco e Paraíba em 13 de agosto de 1759.

A Revolução Industrial dá início a uma nova fase da história da sociedade por ações. Esse movimento traz profundas transformações ao modo de produção de então. Surgem aí as máquinas a vapor substituindo as fontes animais de energia; um novo modo transformação da matéria; e o novo modo de organização, especialização e divisão do trabalho.

HEILBRONER ao tratar do impacto da tecnologia industrial, distingue a Revolução Industrial em quatro fases: (1) máquinas a vapor, novas máquinas têxteis, novos métodos na produção de carvão e na industrialização do ferro; (2) invenções industriais no aço, transportes marítimos e ferroviários, na maquinaria agrícola e nos produtos químicos; (3) energia elétrica, automóveis e motor a gasolina; e, (4) a atual revolução eletrônica, das viagens espaciais, da automação e da energia nuclear ${ }^{72}$.

Foram as profundas transformações dos séculos XVI e XVII que proporcionaram o surgimento da economia de mercado e das sociedades modernas. E na sociedade industrial a empresa privada era o modelo de produção que tinha como arcabouço jurídico a sociedade por ações.

Em LAMY e PEDREIRA encontra-se a assertiva de que até o século XVII toda a produção industrial européia fora acessório do comércio. Foi o surgimento da máquina a vapor, aperfeiçoada por volta de 1780, que trouxe à tona a atividade empresarial $^{73}$.

Com efeito, a Revolução Industrial trouxe a tona um problema que séculos antes já havia sido enfrentado pelos exploradores do Novo Mundo, a necessidade de capital fixo com aportes cada vez maiores. Na busca de capitais, passaram a se interessar por aquela forma societária que caracterizara o período referido das conquistas e que permitira uma eficaz captação de poupança pública. Tal interesse marca nova época na história do instituto.

A Revolução Francesa, por sua vez, apresentou um movimento errático quanto ao tratamento dado às sociedades. De início, em 1791, tendo por pano de fundo o combate às corporações de ofício e aos privilégios, foi dada liberdade total para associações e suprimida a regulamentação do comércio e indústria. De acordo com

\footnotetext{
${ }^{72}$ In ob. cit., p. 102.

${ }^{73}$ In ob. cit., p. 55.
} 
GILISSEN $^{74}$, ocorreram muitos abusos em detrimento dos acionistas, o que levou a Convenção $^{75}$, em 1793, a interditar a constituição de sociedades por ações, salvo autorização. O novo governo, denominado Diretório (1795-1799), restabeleceu a liberdade de associação e, com a ocorrência de abusos, foi editado o Código de Comércio francês de 1807.

Segundo LAMY e PEDREIRA o código trouxe normas que disciplinaram a formação e o funcionamento das sociedades por ações: acabava aí a fase de privilégios, em que a sociedade necessitava lei especial para sua constituição, e começava o regime de autorização $^{76}$.

A solução do Código foi a de autorizar a constituição da sociedade em comandita por ações e a de exigir a autorização governamental (revogável) para a constituição das sociedades por ações. A respeito do Código, MARCOS é firme em dizer que representou um verdadeiro divisor de águas ${ }^{77}$ e que tal medida deu início a um período de grande prosperidade para as comanditas, dando azo a exageros que só foram contidos com lei publicada em 1856.

No Brasil, o príncipe regente D. João cria o Banco do Brasil, por alvará, em 12 de outubro de $1808^{78}$, ocorrendo o primeiro lançamento público de ações no Brasil visando pessoas de posses e grandes negociantes de 1.200 ações no valor de um conto de réis cada uma, tendo durado nove anos esta operação, encerrando-se somente em 1817. O Banco do Brasil iniciou suas atividades em 11 de dezembro de 1809 e, em 1821, com a volta de D. João VI e da Corte a Portugal, carreando os recursos depositados na instituição, sofreu um declínio e, findo o prazo estabelecido para sua duração, o Banco do Brasil foi liquidado em 1833.

VALVERDE $^{79}$ menciona que se enunciou, então, a palavra "estatutos" que passou a designar "a lei reguladora da vida jurídica da sociedade", sem menção à transmissibilidade das ações "como se a livre alienação delas já fosse ponto definitivamente assentado". Adiante menciona a carta régia de 16 de janeiro de 1817 que criou a Companhia de Mineração de Cuiabá na qual os acionistas não podiam retirar o dinheiro ou os escravos com que haviam integralizado o capital, mas podiam transacionar

\footnotetext{
${ }^{74}$ In GILISSEN, John. Introdução histórica ao direito. trad. port. A. M. Hespanha e L. M. Macaísta Malheiros. Lisboa: Fundação Calouste Gulbenkian, 1995, p. 775.

${ }^{75}$ Assembléia Nacional Constituinte, chamada Convenção Nacional ou Convenção, atuou de 1792 a 1795.

${ }^{76}$ In ob. cit., p. 56.

${ }^{77}$ In ob. cit., p. 44.

${ }^{78}$ Ver www.bb.com.br, consultado em 17/09/08.

${ }^{79}$ In ob. cit., pp. 17/19.
} 
livremente as "apólices", termo que, segundo o autor, era usado indistintamente como o termo "ações".

$\mathrm{Na}$ Inglaterra, no que tange ao Bubble Act, segundo HARRIS ${ }^{80}$, a visão acerca da sua eficiência é dúbia. Para aqueles que entendiam que a Inglaterra havia entrado num período de ascensão do capitalismo com o sistema das joint-stock companies, a medida representou um duro golpe ao modelo, levando-o de um período de glória durante os anos de 1689 a 1720 a outro de ostracismo e colapso depois de 1720. No entanto, para aqueles que entendiam que o país passava por uma crise financeira, com queda nos preços das ações e aumento da dívida pública, o Bubble Act não passou de um pequeno incidente que não conseguiu resolver a situação.

Assim, em razão das exigências da classe empresarial, o Bubble Act foi revogado em $1825^{81}$. Entretanto, durante esse período as companhias ficaram submetidas à common law que não reconhecia personalidade jurídica às sociedades, tendo os sócios responsabilidade ilimitada quanto aos negócios da companhia.

O Join-Stock Companies Act de 1844, é entendido como o primeiro diploma inglês a admitir a constituição de companhia sem a necessidade de lei especial, ou autorização governamental. Bastava, para tanto, o registro no "Registro das Companhias", que em verdade compreendia duas fases: uma provisória, antes da subscrição do capital, e outra completa, cujo intuito era o de permitir o funcionamento da companhia. Manteve-se a responsabilidade dos sócios por um período de 3 anos após a transferência das ações ${ }^{82}$.

HARRIS afirma que o registro completo dava à companhia todos os requisitos inerentes a uma companhia: a personalidade jurídica, a livre transferência das ações e a estrutura hierarquizada de administração. No entanto, não gozavam os sócios de limitação da responsabilidade ${ }^{83}$. Somente em 1856, com a edição de um novo Join-Stock Companies Act foi explicitada na Inglaterra a limitação da responsabilidade dos sócios.

Em Portugal e França a liberdade de constituição das companhias veio em 1867; sendo seguidas por Espanha, 1869; Alemanha, 1870; Bélgica, 1873; Hungria, 1875; Suíça, 1881; Itália e Brasil, 1882.

\footnotetext{
${ }^{80}$ In Industrializing english law: entrepreneurship and business organization, 1720-1844. Cambridge: Cambridge University Press, 2000, pp. 60/61.

${ }^{81}$ No dizer de HARRIS "While the company had become more popular with entrepreneurs and investors alike beginning in the late eighteenth century, it was not well received by the dominantly conservative judiciary, and the split between the economic reality and the legal framework reached a critical point. As a result, in 1824-1825, Parliament was forced to put the issue on its agenda for the first time since 1720, and to try to deal with the two conflicting outlooks" in ob. cit, p. 250.

${ }^{82}$ Cf. BULHÕES e LAMY, ob. cit., p. 60.

${ }^{83}$ In ob. cit., p. 283.
} 
No Brasil, até a edição do Decreto n ${ }^{\circ} 575$, de 10 de janeiro de 1849, vigia o regime da outorga real. Após a edição deste normativo, passou a ser exigida a autorização governamental para a constituição da sociedade ${ }^{84}$, referência mantida no Código Comercial de $1850^{85}$, sendo necessária a aprovação do Parlamento quando a sociedade tivesse algum privilégio. Tal orientação teve reforço pela Lei $\mathrm{n}^{\circ} 1.083$, de 22 de agosto de $1860^{86}$, regulamentada pelo Decreto $\mathrm{n}^{\circ} 2.711$, do mesmo ano.

Em 1882, dispensou-se a prévia autorização governamental com a edição da Lei $\mathrm{n}^{\mathrm{o}} 3.150$, de 04/11/1882, sobre sociedades anônimas, regulamentada pelo Decreto $\mathrm{n}^{\mathrm{o}}$ 8.821, de 30/12/1882. Aponta VALVERDE ${ }^{87}$ que a garantia dos terceiros dava-se com a ampla publicidade que acompanha a constituição e a vida das sociedades anônimas.

Posteriormente, tantos foram os normativos editados, que foi publicado o Decreto $n^{\circ} 434$, de 04/07/1891, em que foram consolidadas as "disposições legislativas e regulamentares sobre as sociedades anonymas" ${ }^{\prime \prime 8}$.

Dentre os normativos consolidados, vale recordar o Decreto $\mathrm{n}^{\mathrm{o}} 10.165^{89}$, que, em 1889, explicitou o entendimento de que as sociedades anônimas que tivessem por fim atividades agrícolas e industriais não precisavam de autorização governamental para se

\footnotetext{
${ }^{84}$ Miranda Valverde in ob. cit., p.21, cita a argumentação do então Ministro da Justiça de que a legitimidade dessa intervenção derivava da forma da sociedade anônima uma vez que o item 24 do art. 179 da Constituição de 1824 ("XXIV. Nenhum genero de trabalho, de cultura, industria, ou commercio póde ser prohibido, uma vez que não se opponha aos costumes publicos, á segurança, e saude dos Cidadãos.") dava respaldo a que sociedades anônimas se organizassem livremente, tendo o Conselho de Ministros tomado conhecimento de que várias sociedades anônimas explorando negócios bancários existiam no país sem autorização legal.

85 “Art. 295 As companhias ou sociedades anônimas, designadas pelo objeto ou empresa a que se destinam, sem firma social, e administradas por mandatários revogáveis, sócios ou não sócios, só podem estabelecer-se por tempo determinado, e com autorização do Governo, dependente da aprovação do Corpo Legislativo quando hajam de gozar de algum privilégio: e devem provar-se por escritura pública, ou pelos seus estatutos, e pelo ato do Poder que as houver autorizado."

86 "§ $5^{\circ}$ Em quanto o Governo não declarar constituida huma Companhia ou Sociedade Anonyma, não se poderá emittir, sob qualquer pretexto, titulo algum, cautela, promessa de acções, ou declaração de qualquer natureza, que possa certificar a qualidade de accionista; e ainda depois de constituida, suas acções não serão negociaveis, nem poderão ser cotadas, sem que esteja realisado hum quarto do seu valor."

${ }^{87}$ In ob. cit., p. 27.

88 "Art. $3^{\circ}$ As companhias ou sociedades anonymas, quer o seu objecto seja commercial, quer civil, são regidas pela lei n. 3150 de 4 de novembro de 1882, pelos decretos n. 8821 de 30 de dezembro do mesmo anno, n. 164 de 17 de janeiro, n. 850 de 13 de outubro, n. 997 de 11 de novembro de 1890, n. 1362 de 14 de fevereiro e n. 1386 de 20 de fevereiro de 1891."

${ }^{89}$ Convindo fixar a intelligencia do n. $3, \S 2^{\circ}$, art. $1^{\circ}$ da Lei n. 3150 de 4 de Novembro de 1882 , de conformidade com o parecer do Conselheiro de Estado Dr. Domingos de Andrade Figueira, exarado em Consulta da Secção dos Negocios do Imperio do Conselho de Estado de 9 de Novembro de 1888 sobre o requerimento em que a Companhia Agricola de Campos, em S. João da Barra, pediu autorisação para dar execução á reforma operada em seus estatutos, Hei por bem Declarar que as sociedades anonymas que teem por objecto fins industriaes e agricolas, como a mencionada companhia, não carecem de autorisação do Governo, quer para se organisar, quer para executar as alterações de seus estatutos, regularmente feitas.
} 
organizar, e o Decreto $\mathrm{n}^{\circ} 1.362$, editado no início de 1891, que obrigava as sociedades anônimas a elaborarem prospecto para abrirem subscrição pública.

Ainda careciam de autorização governamental os bancos de circulação, os bancos de credito real, os montepios, os montes de socorro ou de piedade, as caixas econômicas e as sociedades de seguros mútuos, as sociedades anônimas que tivessem por objeto o comércio ou fornecimento de gêneros ou substâncias alimentares e as sociedades anônimas estrangeiras e as suas sucursais ou caixas filiais ${ }^{90}$.

Posteriormente veio o Código Civil de 1916 (Lei $\mathrm{n}^{\circ}$ 3.071) a declarar a personalidade jurídica das sociedades, em seu art. $16^{91}$, mantendo as leis comerciais para as sociedades mercantis $\left(\S 2^{\circ}\right)$. Tal dispositivo consta do art. 1.089 do novo Código Civil de 2002 (Lei no 10.406) que revogou o Código de 1916: “Art. 1.089. A sociedade anônima rege-se por lei especial, aplicando-se-lhe, nos casos omissos, as disposições deste Código".

Já em 1919 foi editado o Decreto no 3.078, tacitamente revogado pelo atual Código Civil que regulamentou inteiramente a matéria ${ }^{92}$, criando a sociedade por quotas de responsabilidade limitada, por inspiração no direito tedesco de 1892 e não nas sociedades de responsabilidade limitada tal como existiram desde 1856 na Inglaterra e desde 1863 em França, conforme apontado por DE LUCCA ${ }^{93}$.

\footnotetext{
90 “Art. 46. Dependem de autorização do Governo para que se possam organizar:

$1^{\circ}$ Os bancos de circulação. (Lei n. 3403 de 24 do novembro de 1888, art. $1^{\circ}$; Decr, n. 10.144 de 5 de janeiro de 1889 , art. $1^{\circ}$; Decr. n. 10.262 de 6 de julho do mesmo anno, art. $1^{\circ}$; Decr. n. 164 de 17 de janeiro de 1890, Art. $1^{\circ} \S 1^{\circ}$ n. 1 ; Decr. n. 165 de 17 de janeiro do mesmo anno, art. $1^{\circ}$ )

$2^{\circ}$ Os bancos de credito real. (Decr. n. 3471 de 3 de junho de 1865, art. $1^{\circ}$; Decr. n. 8821 de 30 de dezembro de 1882, art. 180 n. 4; Decr. n. 169 A de 19 de janeiro de 1890, art. $13 \S 1^{\circ}$; Decr. n. 370 de 2 de maio do mesmo anno, art. 278; Decr. n. 164 de 17 de janeiro do mesmo anno, art. $1^{\circ} \S 1^{\circ}$ n. 2.)

$3^{\circ}$ Os monte-pios, os montes de soccorro ou de piedade, as caixas economicas e as sociedades de seguros mutuos. (Lei n. 3150 de 1882, art. $1^{\circ} \S 2^{\circ}$; Decr. n. 8821 de 30 de dezembro do mesmo anno, art. 130 n. 2; Decr. n. 164 de 17 de janeiro de 1890 , art. $1^{\circ} \S 1^{\circ}$ n. 3.)

$4^{\circ}$ As sociedades anonymas que tiverem por objecto o commercio ou fornecimento de generos ou substancias alimentares. (Lei n. 3150 de 1882, art. $1^{\circ} \S 3^{\circ}$; Decr. n. 8821 do mesmo anno, art. 130 n. 3; Decr. n. 164 de 17 de janeiro de 1890 , art. $1^{\circ}$ n. 4.)"

"Art. 47. Dependem igualmente de autorização do Governo para funccionar na Republica, as sociedades anonymas estrangeiras e as suas succursaes ou caixas filiaes, observando-se, a respeito de taes associações, o seguinte: ..."

91 "Art. 16. São pessoas jurídicas de direito privado:

I - as sociedades civis, religiosas, pias, morais, científicas ou literárias, as associações de utilidade pública e as fundações;

II - as sociedades mercantis;

III - os partidos políticos. (Inciso acrescentado pela Lei no 9.096, de 19.9.1995)

$\S 1^{\circ}$ As sociedades mencionadas no $\mathrm{n}^{\circ}$ I só se poderão constituir por escrito, lançado no registro geral (art. 20, $\S 2^{\circ}$ ), e reger-se-ão pelo disposto a seu respeito neste Código, Parte Especial.

$\S 2^{\circ}$ As sociedades mercantis continuarão a reger-se pelo estatuído nas leis comerciais.

$\S 3^{\circ}$ Os partidos políticos reger-se-ão pelo disposto, no que lhes for aplicável, nos arts. 17 a 22 deste Código e em lei específica. (Parágrafo acrescentado pela Lei no 9.096, de 19.9.1995)"

${ }^{92}$ Cf. DE LUCCA, Newton. Código Civil comentado. Livro II, do direito de empresa. $6^{a}$ ed. São Paulo: Saraiva, 2008, p. 1059/1058.

${ }_{93}^{93}$ In ob. cit., p. 1057.
} 
A responsabilidade dos sócios era limitada à importância total do capital social (art. $2^{094}$ ), encontrando-se dispositivo semelhante no art. $1.052^{95}$ do atual Código Civil. Supletivamente, no que não se encontrasse regulado no contrato social, aplicavamse, segundo o Decreto revogado, as disposições da lei das sociedades anônimas (art. $18^{96}$ ), assunto que foi objeto de grande controvérsia, e, hoje, no caso de omissão aplicam-se as disposições das sociedades simples (art. $1.053^{97}$ ) enquanto a regência supletiva pelas normas das sociedades anônimas deverá ser prevista no contrato social.

Quanto aos títulos de dívida, destacam-se o Decreto $\mathrm{n}^{\circ} 177-\mathrm{A}$, que regulou a emissão de empréstimos em obrigações ao portador (debêntures) das companhias ou sociedades anônimas e o Decreto $\mathrm{n}^{\circ} 22.431$, de 1933, que "Estabelece e regula a comunhão de interesses entre os portadores de debenturas”.

No que se refere às sociedades anônimas, vale comentar que em 1932 foram admitidas as ações preferenciais com limitação ao direito de voto ${ }^{98}$ e que somente após quase meio século foi revogado o vetusto Decreto $n^{\circ} 434$, de 1891 , com a edição do Decreto-Lei $n^{\circ} 2.627$, em 1940. Em regra, as ações preferenciais sem direito a voto não podiam (art. $9^{\circ}$, parágrafo único) ultrapassar a metade do capital da companhia, a exceção das sociedades de economia mista, conforme Decreto-Lei $n^{\circ}$ 6.464, de 1944. Neste quesito, a Lei $n^{\circ} 6.404$, de 1976 , em seu art. $15, \S 2^{\circ}$, passou para dois terços o limite do número de ações preferenciais sem direito a voto ou sujeitas a restrição no exercício desse direito, limite este retornado para a metade do total das ações emitidas pela Lei $\mathrm{n}^{\circ} 10.303$, de 2001. Esta lei de 2001 criou, ainda, a ação preferencial de classe especial, de propriedade exclusiva do ente desestatizante, com poderes de veto (art. 17, $\S 7^{0^{99}}$ ).

$\mathrm{Na}$ regra anterior existia a obrigatoriedade de que um mínimo de sete pessoas subscrevesse todo o capital social $\left(\mathrm{DL} \mathrm{n}^{\mathrm{o}} 2.627\right.$, art. $38, \S 1^{\circ}$ ), enquanto a Lei $\mathrm{n}^{\mathrm{o}}$

\footnotetext{
94 “Art. $2^{\circ} \mathrm{O}$ titulo constituivo regular-se-há pelas disposições dos arts. 300 a 302 e seus numeros do Codigo Commercial, devendo estipular ser limitada a responsabilidade dos sócios à importancia total do capital social."

95 “Art. 1.052. Na sociedade limitada, a responsabilidade de cada sócio é restrita ao valor de suas quotas, mas todos respondem solidariamente pela integralização do capital social."

96 “Art. 18. Serão observadas quanto ás sociedades por quotas, de responsabilidade limitada, no que não for regulado no estatuto social, e na parte applicavel, as disposições da lei das sociedades anonymas."

97 "Art. 1.053. A sociedade limitada rege-se, nas omissões deste Capítulo, pelas normas da sociedade simples.

Parágrafo único. O contrato social poderá prever a regência supletiva da sociedade limitada pelas normas da sociedade anônima."

${ }^{98}$ Decreto no $^{\circ} 21.536$, de 15/06/32.

99 “§ $7^{0}$ Nas companhias objeto de desestatização poderá ser criada ação preferencial de classe especial, de propriedade exclusiva do ente desestatizante, à qual o estatuto social poderá conferir os poderes que especificar, inclusive o poder de veto às deliberações da assembléia-geral nas matérias que especificar."
} 
6.404 criou a companhia até mesmo com um único acionista, a subsidiária integral (art. 251).

Note-se que a Lei $n^{\circ}$ 4.728, editada em 1965 no âmbito da reforma do sistema financeiro nacional, criou a figura do "capital autorizado" bem como a "debênture conversível em ações", regulamentadas na Lei n 6.404 em diversos dispositivos.

O objetivo do projeto de lei da nova lei societária brasileira, Lei ${ }^{\circ} 6.404$, conforme o teor da Mensagem $\mathrm{n}^{\circ}$ 204, de 1976, do Poder Executivo ao Congresso Nacional, era viabilizar o crescimento econômico via captação da poupança popular, oferecendo maior segurança aos acionistas minoritários:

“O projeto visa, basicamente, a criar a estrutura jurídica necessária ao fortalecimento do mercado de capitais de risco no País, imprescindível à sobrevivência da empresa privada na fase atual da economia brasileira. A mobilização da poupança popular e o seu encaminhamento voluntário para o setor empresarial exigem, contudo, o estabelecimento de uma sistemática que assegure ao acionista minoritário o respeito a regras definidas e equitativas, às quais, sem imobilizar o empresário em suas iniciativas, ofereçam atrativos suficientes de segurança e rentabilidade.” (grifei).

Já em dezembro de 2007 foi editada a Lei $n^{\circ} 11.638$, entrando em vigor no dia $1^{\circ}$ de janeiro de 2008, que alterou profundamente as disposições da lei societária no que se refere às informações contábeis com o objetivo de "...modernizar e harmonizar as disposições da lei societária em vigor com os princípios fundamentais e melhores práticas contábeis internacionais...para uma inserção eficiente do Brasil no atual contexto de globalização econômica.” (E.M. nº 57/MF de 19/01/2000). Note-se que alguns dispositivos dessa lei foram alterados pela Medida Provisória no 449, de 3 de dezembro de 2008, editada com o objetivo de compatibilizar as regras societárias e tributárias.

É nesse contexto histórico contemporâneo que pretendemos deter nossa análise acerca da eficiência e maturidade do conceito de capital social. Para tanto, primeiramente verificaremos o conceito, a abrangência e as funções do capital social e então serão analisados os institutos que desnaturam determinadas funções do instituto. 


\section{Capítulo 2. Capital social: noções gerais}

\subsection{Capital social e limitação da responsabilidade}

Do ponto de vista econômico, o empresário exerce três funções: "(i) organizar os fatores de produção, com a constituição ou expansão da empresa; (ii) administrar e gerir a empresa, com a direção das atividades sociais, organizadas com maior ou menor complexidade numa estrutura hierarquizada; e (iii) assumir os riscos empresariais, inerentes à produção e à incerteza da receita auferida com a venda de bens e serviços produzidos." $"$.

Assim, para criar a empresa, os fundadores compõem o capital social que vai permitir o exercício dessas atividades sociais, consentindo tanto a transferência de riscos da empresa para um patrimônio em separado e a limitação da responsabilidade dos sócios, quanto à definição dos direitos patrimoniais e políticos destes.

Com efeito, a criação da pessoa jurídica tem que ver com o desejo das pessoas de se lançar em determinados empreendimentos que, tendo em vista o acúmulo de capital que exigem e o risco a que expõem os seus titulares, demandam algum tipo de proteção do investidor. É aí que surge esse ente personalizado, titular de direitos e obrigações próprias, capaz de assumir os riscos das atividades produtivas, onerando os investidores apenas no montante do aporte de capitais realizado. Não por outro motivo a precisa observação de Francesco FERRARA ao considerá-la uma armadura jurídica, capaz de proteger o homem quando esse decide aventurar-se no mundo dos negócios ${ }^{101}$.

Como a sociedade torna-se um sujeito de direito autônomo, lhe é reconhecido um patrimônio próprio distinto do patrimônio de seus membros, o qual responderá pelas obrigações da mesma. Razão pela qual MUNHOZ afirma que os sócios perdem a propriedade dos bens de produção, adquirindo, em contrapartida, direitos exigíveis contra a sociedade: direito à distribuição dos dividendos, direito à informação e direito à livre transferência das ações, dentre outros ${ }^{102}$.

Daí que a importância do instituto analisado está em ser meio para a limitação da responsabilidade, mormente nas sociedades comerciais, através da

\footnotetext{
${ }^{100}$ PENTEADO, Mauro Rodrigues. Aumentos de capital das sociedades anônimas. São Paulo: Saraiva, 1988, p. 11.

${ }^{101}$ In Trattato de diritto civile italiano. Roma: Athenaeum, 1921, p. 598.

102 MUNHOZ, Eduardo Secchi. Empresa contemporânea e direito societário: poder de controle e grupo de sociedades. São Paulo: Juarez de Oliveira, 2002, pp. 72/73.
} 
constituição de um patrimônio separado ou autônomo daquele de seus membros, que passará a suportar com exclusividade a ação dos credores. PENTEADO, nesse sentido, lembra da posição de Túlio ASCARELLI acerca do tema "capital social”:

“...oferece a terceiros uma tutela no tocante à gestão da empresa, propiciando de outra parte, por meio da publicidade, a identificação de suas relações com o patrimônio social de que é titular a sociedade, este último em contínuo processo de mutação"103.

Segundo ASCARELLI, o princípio da responsabilidade limitada representa exceção frente ao sistema dos princípios jurídicos gerais. Por essa razão a criação de ente personalizado com patrimônio separado se torna também uma exceção ${ }^{104}$. A limitação da responsabilidade seria um privilégio somente consagrado por lei.

No entanto, sabe-se que foi a limitação da responsabilidade que permitiu o desenvolvimento das sociedades anônimas, em grande parte em razão dos reclamos feitos durante o século XIX. Isto porque a constituição de uma pessoa jurídica com patrimônio separado em que se verificava a limitação da responsabilidade representou técnica que permitiu aos homens intentarem negócios sem colocarem em risco seu patrimônio pessoal.

\subsection{Responsabilidade limitada e publicidade dos atos sociais}

Sabe-se que as normas que tutelam a responsabilidade limitada dos acionistas têm que ver mais com as relações externa corporis, isto é, as relações entre a sociedade e terceiros ${ }^{105}$.

Daí exigir-se a publicidade dos atos praticados por tais entes. Isso tem estreita relação com o princípio da integridade do capital social. A publicidade tem que ver com o acompanhamento da vida social, de maneira a demonstrar aos terceiros o estado da companhia, sua gestão, suas modificações estatutárias, etc. Por isso seu caráter de ordem pública.

A publicidade existe para permitir o acompanhamento da modificação do patrimônio social, que, ao contrário da cifra do capital social, não é estático, sofrendo alterações diárias. Isso porque o patrimônio social (separado) é o instrumento da atividade comercial (função produtiva).

\footnotetext{
${ }^{103}$ In ob. cit., p. 13

${ }^{104}$ In Problemas das sociedades anônimas e direito comparado. Campinas: Bookseller, 2001, p. 463.

${ }^{105}$ Cf. ASCARELLI, ob. cit., p. 480.
} 
Assim a publicidade exerce função dupla, uma no sentido de tutela dos terceiros em relação à gestão da sociedade, outra no sentido de se adequar à constante mudança do patrimônio social. E foi precisamente em razão dessa alteração constante do patrimônio social, que foi sendo elaborado o conceito de capital social, acompanhado das normas que tutelam sua integridade.

\subsection{Capital social e patrimônio}

O capital social ganha relevo nas sociedades anônimas precisamente em relação à responsabilidade limitada dos sócios. No entanto, difícil perceber a distinção entre o patrimônio individual e o da empresa quando a atividade empresarial é exercida individualmente ou por poucos sócios (aqui basta lembrar do peculium romano, acima referido), contrariamente ao que ocorre em sociedades, como a anônima, onde esses patrimônios citados são claramente diferenciados.

A palavra patrimônio, por oposição à expressão “capital social”, designa “o conjunto de bens pertencentes a uma determinada pessoa"106, havendo, segundo PENTEADO $^{107}$, duas correntes relacionadas à sua concepção. A primeira, a concepção subjetivista, entendendo o patrimônio como "emanação da personalidade"; já a segunda, a objetivista, como "conjunto de riquezas afeto a um fim”, aspectos melhor abordados adiante em seção específica.

PENTEADO conceitua patrimônio como “a) conjunto de relações jurídicas, tanto ativas quanto passivas; b) apreciáveis economicamente; c) coligadas entre si, por pertinentes a uma pessoa", afirmando que, contrariamente ao que preceituava Pontes de MIRANDA, ele pode estar ligado a várias pessoas, já que ao lado do patrimônio geral, podem coexistir patrimônios especiais voltados para fins previamente estabelecidos ${ }^{108}$.

Para Philomeno J. da $\operatorname{COSTA}^{109}$ patrimônio é o conjunto de bens de um sujeito de direito. Assim que patrimônio bruto é a totalidade dos bens que formam o ativo de uma pessoa, enquanto o patrimônio líquido é a dedução deste último pela soma das obrigações assumidas pela companhia. Em sendo as obrigações superiores ao patrimônio bruto, diz-se que há o passivo a descoberto.

\footnotetext{
${ }^{106}$ Cf. PENTEADO, ob. cit., p. 12

${ }^{107}$ Idem, ibidem.

${ }^{108}$ Idem, p. 13.

${ }^{109}$ In Anotações às companhias, vol. 1. São Paulo: Editora Revista dos Tribunais, 1980, p. 133.
} 
Ambos os conceitos, patrimônio e capital social, são não raro confundidos pela doutrina. Assim, segundo ASCARELLI, o que a lei deseja é a constituição de um capital nominal, fixado no estatuto e que, em suma, representa o produto da multiplicação do número de ações pelo seu valor nominal. Enquanto isso o patrimônio social expressa o valor do ativo da sociedade e o patrimônio líquido, o resultado da conta ativo menos passivo. Segundo o autor, a garantia dos credores encontra-se no patrimônio social, isto é, no conjunto dos seus bens; enquanto o patrimônio líquido tem reflexo no valor da ação ${ }^{110}$.

O capital seria um índice do patrimônio líquido, interessando aos credores na medida em que significa que o ativo da sociedade é maior que o passivo, e interessa também aos investidores, pois indica que há patrimônio do qual eles podem participar ao adquirir as ações.

Com efeito, afirma ASCARELLI que o direito visa tutelar os credores na hipótese de redução do patrimônio em razão de diminuição do capital social; visa, ainda, nunca seja o patrimônio líquido inferior ao capital, isto é, o que se pretende é que o capital social seja efetivamente constituído e mantido ${ }^{111}$.

É importante destacar que se a disciplina do capital visa garantir o direito de terceiros, credores, atuais e futuros, e potenciais investidores, pela manutenção da solvabilidade da companhia, não deve ser esquecido que também visa proteger os direitos patrimoniais do acionista, já que sua participação no patrimônio da companhia é dada em proporção à parte que detém do capital social.

O patrimônio é assim o conjunto dos bens sociais, que varia conforme varia o mercado e os negócios da sociedade, cuja cifra é apontada nos balanços. O capital por sua vez é a cifra fixada desde o estatuto social.

Pode ser que no início da sociedade o capital social e o patrimônio social coincidam $^{112}$. Isso no caso em que as ações são totalmente integralizadas em dinheiro, com um pequeno ágio sobre o valor nominal para compensar os custos de constituição. Se as contribuições dos sócios forem em bens que não dinheiro, a relação entre capital e patrimônio poderá variar conforme varie a avaliação dos bens.

No caso de o patrimônio ser superior ao capital social, haverá a distribuição de lucros ou a alocação de reservas. Roberto PAPINI pontua precisamente esse aspecto. Segundo o autor o capital social constitui cifra de contabilidade enquanto o conceito de

\footnotetext{
${ }^{110}$ In ob. cit., p. 467.

${ }^{111}$ Idem, p. 468.

${ }^{112}$ É essa também a posição de COSTA, cf. ob. cit., p 134.
} 
patrimônio é econômico, correspondendo ao conjunto efetivo de bens da sociedade em um determinado momento ${ }^{113}$.

É essa também a lição de GARRIGUES ${ }^{114}$, para quem o patrimônio é o conjunto efetivo de bens da sociedade em um determinado momento, enquanto o capital social é somente uma cifra permanente da contabilidade que não necessita corresponder a um equivalente patrimonial efetivo, constituindo-se em um patrimônio que deva existir, mas não que efetivamente exista. O capital social representa um conjunto de bens que os acionistas aportam à sociedade e que a sociedade assume o compromisso de conservar, com vistas ao interesse dos credores, em razão da limitação de responsabilidade que é essencial na sociedade por ações.

Daí que embora amplamente relacionados, são realidades completamente distintas ${ }^{115}$. Enquanto o patrimônio é mutável, o capital social é fixo e representado por uma cifra constante do estatuto (conforme preceitua o art. $5^{\circ}$ da Lei $n^{\circ} 6.404 / 76$ ), somente podendo ser alterado em hipóteses previamente estabelecidas (naquelas previstas nos arts. 167 a 174 da Lei $n^{\circ}$ 6.404/76). Há até quem chame o capital social de passivo não exigível, representando um débito da empresa para com o sócio, só que um débito que não pode ser saldado $^{116}$.

A esse respeito, $\operatorname{COSTA}^{117}$ vai afirmar que deve ser afastada a possibilidade de se considerar os bens da companhia, por serem originários, em última análise, do capital aportado pelos acionistas, como propriedade condominial destes últimos. No tocante à participação no patrimônio social, há somente a expectativa, por parte do acionista, de crédito ao quinhão que lhe corresponder na partilha procedida nos termos da liquidação social. Até este ponto, entende-se que o patrimônio é detido unicamente pela companhia.

De qualquer modo, o patrimônio importa em um "fundo real de bens e direitos, efetivo, concreto e continuamente variável na sua composição e montante" ${ }^{\text {"118 }}$.

\footnotetext{
${ }^{113}$ In Sociedade anônima e mercado de valores mobiliários. Rio de Janeiro: Forense, 1999, p. 45.

${ }^{114}$ In ob. cit., p. 134.

${ }^{115}$ Ver a respeito VIVANTE, Tratatto de diritto commerciale, vol. II, Vallardi, Milano, 1929, p. 192.

${ }^{116}$ Cf. PENTEADO, ob. cit., p. 14. LAMY, citando VIVANTE, também propugnava por tal diferenciação em sua obra. Afirmava o professor que "Vivante, em explicação que se tornou de citação obrigatória no assunto, assinala as diferenças entre o patrimônio social, essencialmente mutável, e o capital social, que é uma cifra convencional fixa, de existência de direito e não de fato, que os sócios são livres para acordar no momento de constituição da sociedade, ou de aumentar no curso da vida da sociedade, e que se inscreve no passivo da sociedade", in Temas de S.A.: exposições e pareceres. Rio de Janeiro: Renovar, 2007, p. 181.

${ }^{117}$ Cf. ob. cit., p 34.

${ }^{118}$ Cf. DOMINGUES, Paulo de Tarso. Do capital social: noção, princípios e funções. Coimbra: Coimbra Editora, 1998, p. 41.
} 


\subsection{A tutela legal do capital social: regime geral}

Tendo em vista as características próprias do capital social e do patrimônio é que, ainda citando PENTEADO, a legislação se orienta:

"de um lado, procurando manter a congruência entre capital e patrimônio no momento da constituição da sociedade, mediante regras que, por exemplo, impõem a avaliação dos bens relativos às entradas de capital; de outro com base no chamado 'princípio da integridade do capital', editando uma série de normas que buscam a sua preservação durante a vida da sociedade."

Acerca da tutela do capital social, no dizer de ASCARELLI, existem dois grupos de normas: uma que regula a constituição da sociedade, de maneira que o patrimônio social efetivo não seja inferior ao capital e outra que tutela a proteção deste durante a vida social ${ }^{120}$.

Como normas relativas ao primeiro grupo têm-se, segundo o Autor, as que impedem a emissão de ações abaixo do valor nominal, ou ainda por série, de maneira que é vedado que o capital social seja utilizado para remunerar os fundadores ou quem propiciar a distribuição das ações (os quais só podem ser remunerados com os lucros sociais de acordo com os arts. 47 e 84 da Lei $n^{\circ}$ 6.404/76); as que exigem a contribuição imediata de pelo menos uma parte do valor de subscrição, não se admitindo a distinção entre um capital subscrito e um capital autorizado; outras ainda limitam a circulação das ações relativas à contribuição em bens ou sobre as quais não tenha sido efetuada a entrada de uma determinada porcentagem: e as que vedam o aumento de capital antes que o capital anterior tenha sido integralizado (de acordo com os arts. $8^{\circ}, 29,80$ e 170 da Lei $n^{\circ} 6.404 / 76$ ).

Note-se que ele faz a ressalva de que o capital social deve ser constituído a partir de economias já existentes e não de esperanças de que os subscritores possam, no longo prazo, integralizar todas as ações.

Como normas do segundo tipo, qual seja, normas que visam à manutenção do capital social ao longo da vida societária, tem-se aquela que veda ou limita a distribuição de juros aos acionistas (art. 179, V, da Lei $n^{\circ}$ 6.404/76); aquela que veda a distribuição de dividendos antecipados ou fictícios, isto é, não resultantes de lucros prévios

\footnotetext{
${ }^{119}$ Cf. PENTEADO, ob. cit., p. 14. A esse respeito, confrontamos posições diversas a essa abaixo quando tratamos das acepções do capital social.

${ }^{120}$ In ob. cit., p. 473.
} 
(arts. 133, 176 e 193 da Lei no 6.404/76 e 177 do Código Penal); aquela que impede que a esperança de lucro seja encarada ou distribuída como se lucro fosse (arts. 167 e 297 da Lei $n^{\circ}$ 6.404/76); a que impõe a constituição de reserva legal (art. 183 da Lei ${ }^{\circ} 6.404 / 76$ ) ${ }^{121}$; a que impede a distribuição de dividendos antes da reconstituição do capital social, em caso de perda anterior; a que proíbe ou limita a possibilidade de a sociedade negociar com suas ações; a que impõe a liquidação e em alguns casos até mesmo a falência da sociedade sempre que o capital social seja diminuído além de uma determinada medida; aquela que tutela a veracidade e a publicidade do balanço, de modo a permitir que os terceiros possam acompanhar os negócios sociais.

Estudaremos no ponto seguinte a disciplina legal do capital social e as normas que o estruturam observando o desenvolvimento das funções que implementa.

\subsection{O sistema de constituição do capital social na Lei $n^{\circ} 6.404 / 76$ (arts. $5^{\circ}$ a 10 )}

\subsubsection{Alteração do capital social}

Entende Fran MARTINS ${ }^{122}$ que, ao subscrever as ações, os acionistas se tornam devedores da companhia, por terem assumido a obrigação de pagar a importância subscrita. Enquanto eles não pagam a totalidade do valor, o que falta entra no ativo da companhia.

Outro aspecto da proteção dos credores está no fato de ser vedado emitir ações abaixo do seu valor nominal. Fosse permitido o contrário, os credores seriam fraudados caso considerassem que o valor representativo seria aquele efetivamente apurado.

E mais: mesmo que as ações não tenham valor nominal, deve fixar-se o número de ações e o total do capital (confere-se, assim, valor patrimonial à ação). Esta

\footnotetext{
${ }^{121}$ Em nota sobre assunto assim escreve Ascarelli: “A impossibilidade de levar em conta o fato de ser o preço do mercado de bens superior ao preço de custo e a obrigação, ao contrário, de levar em conta o preço de mercado, quando inferior ao preço de custo (cf. art. 129, Decreto-Lei no 2.627, de 26 de setembro de 1940, e art. 183 da Lei $\mathrm{n}^{\circ}$ 6.404, de 15 dezembro de 1976), decorrem do princípio de que, quanto à determinação dos lucros distribuíveis da sociedade, é mister atender à tutela dos terceiros credores. Este princípio explica por que haja, às vezes, um contraste entre as normas do direito privado e aqueles do imposto de renda no que respeita à determinação do lucro; realmente, as primeiras cuidam, antes de mais nada, da determinação do lucro e do lucro distribuível visando à tutela dos terceiros credores da sociedade; as segundas, ao contrário, visam à determinação do lucro tributável da sociedade, levando em conta as exigências do fisco".

${ }^{122}$ In Comentários à lei das sociedades anônimas, vol. 1. $3^{\mathrm{a}}$ ed. Rio de Janeiro: Forense, 1989, p. 53.
} 
forma pode ser inclusive vantajosa, pois as ações são negociadas pelo seu valor no mercado, e não por algo preestabelecido que pode estar distorcido.

O princípio da fixidez do capital pode ser mitigado, de acordo com a situação presente da companhia: pode-se aumentar o capital para que a injeção de recursos venha a ajudar no desenvolvimento da companhia, ou diminuí-lo, para que ele se adéque a uma situação crítica presente da empresa. Este último artifício, inclusive, é salutar para o mercado em geral, pois, caso não ocorresse a diminuição, poderia considerar-se que o capital social da companhia em dificuldade seria "fictício".

Eventualmente, o estatuto da companhia poderá dispor que há um capital autorizado para ela, não havendo necessidade de reformá-lo, desde que o aumento encontre-se no limite autorizado. Igualmente, caso haja debêntures conversíveis em ações, o capital social poderá ser alterado sem deliberação, no ato da conversão.

Ainda no que respeita à modificação do capital, e em relação ao que dissemos acima, o capital poderá ser alterado por Assembléia Geral Extraordinária que, por quorum simples da maioria absoluta dos presentes, pode alterar o estatuto com este fim.

Já no caso de diminuição do capital social, isto pode ocorrer de algumas formas, dentre elas: a realização de uma Assembléia Geral, após perda de capital, na qual este pode ser diminuído até compensar os prejuízos; uma outra Assembléia Geral para, quando os empreendimentos da companhia não exigirem grandes recursos, reduzir o capital para adequá-lo à realidade; também em Assembléia Geral, poderá haver redução quando houver reembolso de ações, em caso de acionistas dissidentes em determinadas matérias; e ainda no caso de resgate das ações no mercado (podendo haver, no entanto, resgate sem diminuição do capital, atribuindo novos valores às ações remanescentes).

Os credores, no caso de redução voluntária do capital pela companhia (o que excetua o reembolso aos dissidentes, por exemplo), podem opor-se a tal redução, que seria possibilitada somente se fossem pagos seus créditos ou então se feito depósito judicial da quantia devida. Ainda, se existissem debêntures em circulação, a redução só poderia ser efetivada com a aprovação da maioria dos debenturistas reunidos em Assembléia Geral.

\subsubsection{Os bens aptos a serem subscritos}

A preferência, obviamente, é que a subscrição das ações deva ser feita em dinheiro. Pode-se optar (de acordo com o prospecto) pela subscrição com pagamento 
integral ou parcelado, sendo necessário apenas que ao menos $10 \%$ (apenas se o estatuto não previr diversamente) do preço de emissão seja subscrito na ocasião da subscrição.

Por outro lado, há a opção de subscrição com bens que deverão ser avaliados. Desta forma, exonera-se o acionista de pagar ao menos $10 \%$ da entrada. Mas, se concorrer, para a subscrição, com bens e dinheiro, a quantia mínima passa a ser exigida.

Os bens oferecidos pelo acionista poderão ser móveis ou imóveis, corpóreos ou incorpóreos, desde que suscetíveis a avaliação. Isto faz com que bens como know-how ou marcas possam ser utilizados para subscrever ações.

Caso o acionista subscreva as ações com crédito, ele será responsável pela solvência do mesmo, mesmo se a sociedade eventualmente cedê-lo ou transferi-lo.

\subsubsection{As regras de avaliação de bens}

A avaliação dos bens oferecidos para subscrição pode ser feita por três peritos, nomeados por Assembléia Geral dos subscritores, sendo livre a escolha dos profissionais, requerendo somente que ele possua a expertise necessária à tarefa. Esta Assembléia, em primeira convocação, deve ter a presença de subscritores que representem ao menos metade do capital social. Não atendido este quorum, a Assembléia, em segunda convocação, se reunirá com qualquer número de subscritores.

MARTINS $^{123}$ acredita que o fato da Assembléia em $2^{\text {a }}$ convocação poder ser instalada com qualquer número de subscritores pode dar margem a atos lesivos à sociedade, uma vez que uma minoria ínfima poderia nomear peritos com o intuito único de avaliar fraudulentamente os bens usados para subscrição de ações (isto apesar da previsão legal de responsabilidade nestes casos, atribuível a subscritores ou avaliadores quando estes procederem de tal modo com culpa ou dolo).

Há a possibilidade de nomear empresas para a avaliação destes bens, o que, segundo o mesmo autor, é positivo pelo fato delas serem menos "influenciáveis" em sua tarefa. O subscritor que oferece seus bens pode participar da assembléia de designação de peritos, inclusive impugnando-os fundamentadamente, mas não pode fazer parte da assembléia de aprovação do laudo de avaliação, por conflito de interesses expressamente previsto na lei societária (art. $115, \S 1^{\circ}, 1^{\mathrm{a}}$ parte $^{124}$ ).

\footnotetext{
${ }^{123}$ In ob. cit., p. 68.

124 “\$ $1^{\circ}$ o acionista não poderá votar nas deliberações da assembléia-geral relativas ao laudo de avaliação de bens com que concorrer para a formação do capital social ..."
} 
Os avaliadores terão de eleger e explicar os critérios utilizados para a avaliação, havendo, inclusive, matérias nas quais tais critérios já são oficializados, como no que concerne a bens imóveis. Não há prazo fixo para a apresentação do laudo que, no entanto, deve ser entregue em prazo razoável para que não atrase a constituição da companhia.

A partir do oferecimento do laudo, basta que sejam respeitados os prazos para a convocação de assembléia para apreciação da avaliação. Neste conclave, segue fixo o quorum para funcionamento em relação ao de designação de perito, tanto em uma primeira quanto em uma segunda eventual convocação.

Diz MARTINS ${ }^{125}$ que, caso o subscritor não concorde com a avaliação dada aos seus bens, poderá ele cancelar a subscrição, ato que cancelará o projeto de constituição da companhia, que teria o mesmo destino caso a assembléia não venha a aceitar o laudo apresentado.

Mesmo que os bens oferecidos para subscrição pertençam em condomínio a todos os subscritores, eles deverão passar por avaliação da mesma forma, pois o capital social formado pela companhia não interessa somente a ela em si, mas sim a todos os terceiros que irão operar com a empresa, necessitando, desta forma, de uma correspondência entre o valor dado ao bem e o valor real do mesmo.

Apesar dos bens incorporados ao patrimônio da companhia não poderem fazê-lo por valor superior ao dado pelo subscritor, caso isto ocorra deve-se proceder à devolução, ao acionista que oferece o bem, do valor do bem que supera o valor das ações subscritas. Reitera-se a responsabilidade de subscritor e avaliadores do bem, em caso de atribuição de valor fictício, perante não apenas a companhia, mas também frente aos acionistas e terceiros.

\subsubsection{A transferência dos bens à sociedade e a responsabilidade do subscritor}

Há a possibilidade de os bens para subscrição não terem transferência de propriedade, mas sim de outro título, como o usufruto. No caso de bens móveis, basta a tradição para a transferência dos mesmos. Para bens imóveis, é necessária a transcrição no registro de imóveis e a outorga uxória. No caso de bens incorpóreos, cada tipo será

${ }^{125}$ In ob. cit., p. 71. 
transferido de acordo com suas regras próprias (no caso de patentes, p. ex., deverá ser seguido o Código de Propriedade Industrial).

MARTINS, apesar de favorável à subscrição através da transferência de título de usufruto, é contra a possibilidade de um usufrutuário oferecer tal título à companhia, pois, perecível como é o direito deste, isto faria com que não houvesse certeza ou fixidez sobre o direito adquirido pela empresa ${ }^{126}$.

Na transferência destes bens para a companhia a título de subscrição, não será devido imposto de transmissão, por não considerar, apesar da passagem do bem de uma pessoa para outra, que este seria um ato de venda.

Sobre a discussão a respeito da necessidade de se pagar ICMS sobre os bens móveis transmitidos à sociedade, MARTINS expõe duas teorias: uma afirmando que, por serem tais bens incorporados no ativo fixo da companhia, não estariam sujeitos a tal cobrança; outra, ao contrário, sustentando que, pela interpretação de que o que entra no capital social da companhia é o valor do bem e não este em si mesmo (de que a sociedade poderá dispor posteriormente), seria cabível tal tributação ${ }^{127}$.

Continua o autor afirmando que bens ou utensílios que o subscritor não utilizava ou não possuía finalidade de venda, tais como maquinários, não deveriam ser tributados pelo ICMS, pois circulação de mercadoria pressuporia exatamente o contrário quanto à finalidade do subscritor quanto ao bem.

Por responsabilizar subscritores, pelo bem oferecido, da mesma forma que um vendedor, a lei intenciona justamente que eles respondam por eventuais vícios ocultos existentes em tais coisas.

\subsection{Capital social e reservas}

ASCARELLI cuida de modo especial da diferenciação entre capital e reservas. Segundo o Autor, tal diferença tem como ponto fundamental as regras de tutela do direito dos terceiros, que assentam, sobretudo, na disciplina do capital social. Ele condena, no entanto, a argumentação segundo a qual o capital é propriedade dos acionistas e as reservas da sociedade, isto porque ambos são apenas indicações do valor do patrimônio líquido e não coisas, não podendo ser objeto de direito real ${ }^{128}$.

\footnotetext{
${ }^{126}$ In ob. cit., p. 74.

${ }^{127}$ In ob. cit. p. 75.

${ }^{128}$ In ob. cit., p. $470 / 471$.
} 
Com efeito, para ele, mais próxima da realidade é a teoria segundo a qual as reservas seriam propriedade dos acionistas e o capital social garantia dos credores. Ainda que inexata, tendo em vista a garantia dos credores ser representada pelo patrimônio social e o direito dos acionistas pelo patrimônio líquido, essa teoria tem a vantagem de ressaltar que a diferença substancial entre os conceitos assenta na tutela dos credores sociais.

Os acionistas têm direitos patrimoniais que correspondem em proporção ao valor do capital e das reservas. No entanto, a diferenciação entre um conceito e outro tem que ver, substancialmente, com a proteção dos terceiros frente aos negócios sociais, daí que as reservas podem ser distribuídas aos sócios, sem o respeito a regras tão rígidas quanto as normas que tutelam a diminuição de capital.

Alexandre Demetrius PEREIRA diz acerca das reservas que todas são obtidas segundo o mesmo procedimento contábil e que consiste em retirar do lucro determinada parcela para prover um fundo para a caução de futuras operações ou necessidades, ou ainda para garantir pagamentos ainda não realizados. Explica ainda o autor que elas não podem prejudicar a distribuição de dividendos obrigatórios, da mesma maneira que não podem ultrapassar o valor do capital social ${ }^{129}$.

Seja como for, o direito quer que a sociedade indique qual o seu capital, sujeitando-o a uma disciplina particular. Quer o direito ainda, que a sociedade apresente sempre um patrimônio líquido não inferior à cifra do capital social.

\title{
2.7. A essencialidade do instituto, segundo o sistema legal
}

Em outros países, as sociedades desprovidas de capital já foram ou são admitidas e, no Brasil, já houve proposta de sua criação:

\begin{abstract}
“Anteprojeto de Lei que dispõe sobre associações de interesses econômicos, as quais podem ser constituídas com ou sem capital social, respondendo as pessoas que delas participarem solidária e ilimitadamente pelas suas dívidas, salvo estipulação em contrário com credor determinado" 130
\end{abstract}

\footnotetext{
${ }^{129}$ In $O$ exercício social $e$ as demonstrações financeiras. Os lucros, as reservas $e$ os dividendos in VERÇOSA, Haroldo Malheiros Duclerc. Curso de direito comercial, vol. 3. São Paulo: Malheiros, 2008 , p. 600.

${ }^{130}$ Anteprojeto publicado na Série Cadernos Técnicos, n. 15, editada pelo Conselho de Desenvolvimento Comercial do Ministério da Indústria e do Comércio, Brasília, 1983 cf. PENTEADO, ob. cit., p. 15.
} 
De fato, essas espécies societárias são exceção por não darem margem à limitação da responsabilidade, apenas colocando esse patrimônio separado como prioridade na garantia dos credores, sem que se exclua a responsabilidade subsidiária dos sócios, que, percebe-se, não é limitada.

A bem da verdade, o capital social é elemento indispensável nas sociedades que tradicionalmente a doutrina chama de sociedades de capital, como se pode observar na companhia e na sociedade limitada.

A indispensabilidade desse instituto reside nas funções, dentre outras, como será analisado infra, que exerce de prestar um tipo de garantia aos credores da companhia, de determinar o poder no interior da sociedade (a qual é conhecida como função política) e de dar ao sócio tal status, fixando também seus direitos sociais. Daí porque alguns autores afirmam ser um instituto fundamental à vida social ${ }^{131}$.

Daí, podemos concluir que o capital social é de suma importância nas sociedades de capital, embora não seja essencial à noção de sociedade, aparecendo eventualmente nas sociedades de pessoas e, também nestas, desempenhando papel importante para o regime jurídico ${ }^{132}$.

\subsection{As acepções do capital social}

Embora muitos acreditem que pouco importaria para o jurista o estudo do instituto do capital social, já que, para determinar seu significado bastaria recorrer à resposta dos economistas, deve-se perceber que as definições econômicas e jurídicas nada têm a ver uma com a outra.

Isso se deve ao fato de o economista analisar o capital social desde o ponto de vista da produtividade da empresa, enquanto o jurista analisa, sobretudo, a constituição e o a conservação de um fundo de garantia aos credores.

Como será analisado pontualmente mais à frente, em alguns países, pela exigência do capital mínimo, fica fácil de se observar que tanto o conceito econômico quanto o conceito jurídico estão abarcados pelo instituto, tutelando-se tanto a proteção dos credores quanto da economia, ao se impedir a constituição de companhias de vida frágil e

\footnotetext{
${ }^{131}$ Cf. GARRIGUES, Juan Bolás Alfonso. La sociedad de responsabilidad limitada. Madrid: Editora Civitas, 1992, p. 65, e ULIBARRI, Adrián Celaya. Capital y sociedad cooperativa. Madrid: Editorial Tecnos, 1992. p, 35; citados por DOMINGUES, ob. cit., p. 24.

${ }^{132}$ Nesse sentido, COZIAN, Maurice; VIANDIER, Alain et DEBOISSY, Florence. Droit des Societés. $18^{\mathrm{a}}$ ed. Paris: Litec, 2005, p. 106.
} 
efêmera. A concepção de VIVANTE vem corroborar essa afirmação, pois, segundo ele, o capital social é "elemento moderador legal e contabilístico da vida social"133.

Em verdade, o capital social é importante para a compreensão de determinadas figuras da sociedade, por exemplo, a integridade do capital social, o aumento e redução do capital, as sociedades de capital, o balanço, lucro, etc. O instituto, como bem coloca DOMINGUES ${ }^{134}$, apresenta diversas acepções. Passaremos a discorrer sobre as principais.

\subsubsection{O conceito contábil de capital}

Para a quase unanimidade dos autores que escreveram ou ainda escrevem sobre o tema, o capital social, que consta do passivo e, logo, do lado direito do balanço, constituindo uma verba do capital próprio, é uma entidade puramente contábil. Nesse sentido, interessante notar a posição de Wilson BATALHA a esse respeito:

“Capital social é a cifra indicativa das contribuições que os sócios fazem, ou se obrigam a fazer, em pecúnia, bens ou direitos, para que a sociedade possa desempenhar os seus objetivos, indicando, outrossim, a importância monetária que, incluída no passivo, representa uma responsabilidade potencial perante terceiros e acionistas (...)"135

No entanto, embora conste do passivo, o capital social não é, necessariamente, uma dívida da sociedade, como considera outro grupo de autores, que o entendem como uma dívida da sociedade para com os sócios, uma vez que eles poderiam exigir o pagamento da contribuição que fizeram a ele ${ }^{136}$.

De fato, a razão de o capital social constar do lado direito do balanço não tem a ver com ser ele dívida da sociedade para com os sócios, mas porque essa é a forma de reter no ativo da companhia os bens necessários para cobrir a respectiva cifra. Assim

\footnotetext{
${ }^{133}$ In ob. cit., p. 192.

${ }^{134}$ In ob. cit., pp. 32/50.

${ }^{135}$ In Comentários à Lei das Sociedades Anônimas, vol. I. Rio de Janeiro: Forense, 1977, p. 110.

${ }^{136}$ Nesse sentido, entre outros, GUYON, ob. cit., p. 106.
} 
funcionando como limite mínimo de distribuição de lucros e demais dividendos ou bonificações, sem que isso afete a atividade empresarial ${ }^{137}$.

A contabilidade o define, em suma, como o investimento efetuado pelos acionistas na sociedade abrangendo não somente as contribuições feitas no momento de constituição da companhia, mas também todos aqueles valores que, segundo decisão dos proprietários se incorporam ao capital social, representando como uma renúncia aos bens que a sociedade distribui ${ }^{138}$.

O capital social não se constitui simultaneamente com a formação da sociedade, podendo passar por fases. Isto porque se permite que o subscritor aporte, como entrada, pelo menos $10 \%$ da contribuição acordada, podendo o resto ser protelado. Distingui-se, desta forma, Capital Subscrito (prometido) e Capital Realizado (já pago), faltando para que se igualem o Capital a Realizar ${ }^{139}$.

Em verdade, aquilo que se chama de Capital Realizado tem que ver com o disposto no art. 182 da Lei $n^{\circ}$ 6.404/76 em que se exige a discriminação do montante subscrito e da parcela ainda não realizada do capital social. Uma vez discriminadas tais contas, a parcela líquida delas resultante representará o capital realizado ${ }^{140}$.

Há, ainda, a figura do Capital Autorizado, pela qual se entende a previsão de um futuro capital social maior, embora, num primeiro momento, a sociedade seja constituída com um montante menor. O "limite" previsto é o que se chama de Capital Autorizado. Sabe-se que a informação de capital autorizado deve ser divulgada nas demonstrações contábeis, no balanço, na conta Capital, ou mesmo no topo das demonstrações contábeis ${ }^{141}$.

\footnotetext{
${ }^{137}$ DOMINGUES, no entanto, vai dizer que essa teoria (a do capital como cifra contábil), no entanto, não está livre de críticas. As principais referem-se ao fato de ser muito redutora e unilateral. Unilateral porque à cifra constante do passivo tem que corresponder uma massa de bens do ativo, assim como têm que corresponder a essa massa de bens do ativo, aquela outra massa de bens do passivo (capital real); redutora porque parece deixar de lado a importância que o capital social tem em outras matérias, como a determinação da posição do sócio na companhia e o direito de voto, in ob. cit., p. 34.

${ }^{138}$ Cf. FUNDAÇÃO INSTITUTO DE PESQUISAS CONTÁBEIS, ATUARIAIS E FINANCEIRAS. Manual de contabilidade das sociedades por ações: aplicável às demais sociedades / FIPECAFI. diretor responsável Sérgio de Iudícibus; coordenador técnico Eliseu Martins; supervisor de equipe de trabalho Ernesto Rubens Gelbcke. $7^{\text {a }}$ ed. $4^{\text {a }}$ reimpr. São Paulo: Atlas, 2008, p. 313. Fundamental advertir que tais autores lembram que o instituto é figura mais ligada ao direito que à economia, porquanto "do ponto de vista econômico, também os lucros não distribuídos, mesmo que ainda na forma de Reservas, representam uma espécie de investimento dos acionistas" idem, ibidem.

${ }^{139}$ Cf. COSTA, ob. cit., p 135.

${ }^{140}$ Cf. FIPECAFI, ob. cit., p. 313.

${ }^{141}$ Idem, p. 314.
} 


\subsubsection{O capital social como soma das contribuições dos sócios}

LAMY traz a seguinte afirmação que parece seguir na linha do entendimento de que capital social é soma das contribuições dos sócios: "no nosso velho Código Comercial, já o art. 287 prescrevia ser da essência de toda sociedade mercantil que cada um dos sócios contribua para o capital social com alguma cota"142.

Dentro do setor da doutrina que enxerga o capital social como a soma dos apports dos sócios, há, segundo dicção de DOMINGUES ${ }^{143}$, uma divisão em duas correntes.

Para a primeira, o capital social é o equivalente à soma dos bens que constituem as entradas dos sócios (acepção material); para a segunda, é uma entidade numérica correspondente ao valor das entradas dos sócios no momento da constituição da sociedade (acepção formal).

A acepção material do instituto, que foca o seu caráter concreto e real, foi adotada pela jurisprudência italiana. Considera-se assim que o capital social são os bens da sociedade provenientes das entradas dos sócios, de maneira que todos os outros bens que a sociedade venha a adquirir de outra proveniência compõem o patrimônio social $^{144}$. A maioria dos autores, no entanto, segue a acepção formal ${ }^{145}$.

DOMINGUES $^{146}$ traz várias críticas para esta teoria, qual seja, a do capital social como soma das entradas dos sócios, em sua acepção formal. Entre estas se deve mencionar aqui a idéia de que se o capital social é composto pela quantia em dinheiro dos bens destinados à sociedade pelo sócio a título de entrada, não se pode aumentar a cifra do capital sem novas entradas, como ocorre quando há a incorporação de reservas ou reavaliação do ativo.

O mesmo acontece no caso de redução do capital social por perdas, pois nesse caso não haverá devolução proporcional das entradas dos sócios.

\footnotetext{
${ }^{142}$ In Temas de S.A.: exposições e pareceres. Rio de Janeiro: Renovar, 2007, p. 179. Com efeito, a redação do citado dispositivo era a seguinte: “Art. 287 - É da essência das companhias e sociedades comerciais que o objeto e fim a que se propõem seja lícito, e que cada um dos sócios contribua para o seu capital com alguma quota, ou esta consista em dinheiro ou em efeitos e qualquer sorte de bens, ou em trabalho ou indústria."

${ }_{143}$ Cf. ob. cit., p. 35.

${ }^{144}$ Cf. SIMONETTO, Ernesto. Concetto e composizione del capitale sociale, RivDCom, anno LIV (1956). Citado por DOMINGUES, ob. cit, p. 14.

${ }^{145}$ Cf. GALGANO sustenta ser o "capital social a entidade numérica que exprime o valor das entradas prometidas ou realizadas" in La società per azioni in Tratato di diritto commerciale e di diritto publico dell'economia, vol. VII. Padova: CEDAM, 1988, p. 11; vide ainda GUYON, ob. cit., p. 102.

${ }^{146}$ Cf. ob. cit., pp. $37 / 39$.
} 
Deve-se lembrar, sobretudo a respeito dessa teoria, que a caracterização do capital social como soma das entradas dos sócios importaria em desconsiderar a função de garantia e outras que se aplicam ao instituto.

Ora, não é o capital social que se determina em função das contribuições, porque este é previamente estabelecido para que depois sejam definidas as participações dos sócios; ou seja, as contribuições dos sócios só adquirem o valor jurídico de contribuição para o capital social quando se destinam a cobrir o montante do capital social.

\subsubsection{O capital social como cifra formal e abstrata}

LAMY FILHO é assente em afirmar acerca do capital que "trata-se, pois, de uma noção jurídica e contábil, não patrimonial", embora advirta que "deve corresponder necessariamente a valores do ativo da empresa, para garantia dos credores" ${ }^{, 147}$.

A concepção abstrata ou nominalista é a mais difundida acerca do capital social. Com efeito, ela entende o instituto como uma cifra numérica, apartada da realidade e inalterável, ou seja, um puro nomen iuris $^{148}$. Por essa razão, faz sentido lembrarmos aqui da distinção que fizemos acima entre patrimônio e capital social, porquanto, se o patrimônio social é tangível, o capital social, pelo menos nessa acepção, seria um puro nomen iuris e importaria numa cifra ideal, fora da realidade, e constante, existindo apenas de direito e não de fato ${ }^{149}$.

Também o patrimônio, como o capital social, tem diversas acepções, como (i) a de patrimônio global, ou seja, o conjunto de direitos e obrigações de uma determinada pessoa suscetíveis de avaliação pecuniária; a de (ii) patrimônio ilíquido ou bruto, composto somente dos elementos do ativo da sociedade, sem se levar em conta o passivo; e, por fim, (iii) a de patrimônio líquido, em que se considera os elementos do ativo, descontados os do passivo.

Entretanto, aqui também DOMINGUES ${ }^{150}$ aponta fraquezas da tese. Segundo ele o capital social pode variar, para mais ou para menos, quando do cumprimento de determinados requisitos. A noção de capital social como cifra formal e abstrata, além de não ser compatível com o instituto da perda do capital, é muito redutora e

\footnotetext{
${ }^{147}$ In ob. cit., p. 182.

${ }^{148}$ Cf. COZIAN e VIANDIER, ob. cit., pp. 97/98.

${ }^{149}$ Cf. VIVANTE, ob. cit., p. 192.

${ }^{150}$ In ob. cit., pp. 42/43.
} 
não consegue explicar a função do capital de garantia para terceiros, já que os credores não ficam garantidos por uma cifra, mas sim por um conjunto de bens suscetíveis de penhora.

\subsubsection{O capital social como capital nominal e capital real}

Há autores que visualizam o capital social como realidade una, mas complexa, que não se expressa por um único perfil, esboçando duas vertentes, a do capital social nominal e a do capital social real.

Se o capital social for considerado uma cifra e aí constar do lado direito do balanço, implica que no ativo (lado esquerdo do balanço) existem bens que cobrem, no mínimo, aquela cifra.

Dessa forma, o capital social expressa não só a cifra, mas também os bens da sociedade destinados a cobri-la, ou seja, a sua outra face, o capital real.

É possível, então, percebemos que o capital social real é a quantidade de bens que a sociedade tem de manter intacta, porquanto se destina a cobrir o valor do capital social nominal inscrito no lado direito do balanço. E aí uma divergência doutrinária. Enquanto assevera VIVANTE ${ }^{151}$ que o capital nominal e o capital efetivo, patrimônio, são distintos, para DOMINGUES o capital social real não é conceito idêntico ao patrimônio, mas uma esfera concêntrica menor dentro deste. Ainda assim, o autor português afirma que:

"se o valor do patrimônio líquido for inferior ou idêntico ao do capital social nominal, então o capital social abrangerá e confudirse-á com a totalidade dos bens que constituem aquele patrimônio da sociedade." 152

O capital social real pode ser considerado como composto pelos bens que formam as entradas dos sócios na medida em que a qualidade dos elementos que integram o capital social só pode ser realizada no momento da sua constituição. Depois desse momento, o capital social real será constituído por quaisquer bens do patrimônio da sociedade que equivalham ao valor do capital social nominal.

Nesse sentido, COSTA define capital social como o montante, fixado inicialmente, dos bens com que a sociedade desenvolverá as suas atividades lucrativas

\footnotetext{
${ }^{151}$ In ob. cit., p. 192.

${ }^{152}$ In ob. cit., p. 49.
} 
esclarecendo que a massa de bens da companhia não serve somente à consecução dos objetivos da empresa, mas também uma garantia de confiança para com quem ela contrata. O capital social, desta forma, conferiria segurança aos empreendimentos ${ }^{153}$.

É nessa perspectiva que Haroldo VERÇOSA nos diz que o sistema legal brasileiro é do capital declarado (stated capital), donde a cifra ali expressa não representa necessariamente o valor das contribuições dos sócios, mas sim o valor que é declarado pelos acionistas ${ }^{154}$.

Por fim, ao se falar na função de garantia dos credores que exerce o capital social, está-se a enxergá-lo como capital social real, já que os credores são pagos com bens concretos e não com cifras. Daí a assertiva de PAPINI de que:

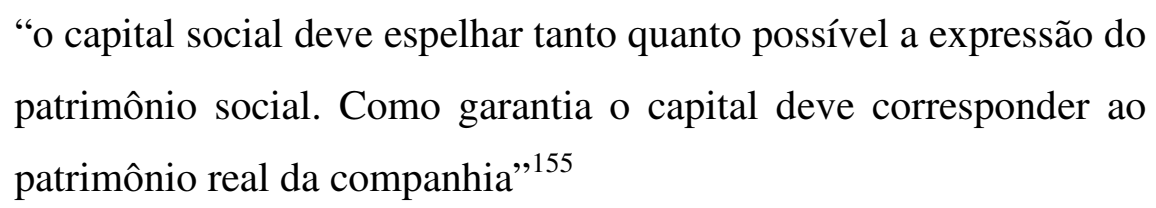

Assim, podemos, concluir, pela explanação de DOMINGUES ${ }^{156}$, que o capital social é um fenômeno complexo ainda que unitário - é tanto uma cifra estável constante do estatuto, como também uma massa de bens, fração ideal do patrimônio líquido e que se destina a cobrir o valor do capital social nominal.

\subsection{As funções do capital social}

Segundo a doutrina, dentre as várias funções exercidas pelo capital social, estão, como as mais comuns e mais importantes, as de garantia, de produtividade e a política, conforme se desenrola a atividade empresarial.

Dentre essas funções, que podem ser vistas sob as óticas interna e externa, estão, no primeiro caso, as funções de garantia, as funções de avaliação econômica da empresa e a função de socialização; e, no segundo, as funções de atribuição de qualidade de sócio, a de determinação da posição jurídica de sócio a de distribuição do poder societário (que aqui chamamos política) e a de produtividade.

\footnotetext{
${ }^{153}$ In ob. cit., p 129.

${ }^{154}$ In Curso de direito comercial, vol. 3. São Paulo: Malheiros, 2008, p. 129.

${ }^{155}$ In ob. cit., p. 47.

${ }^{156}$ In ob. cit., pp. $48 / 49$.
} 


\subsubsection{A função de garantia}

Inicialmente o capital social surgiu não como uma garantia a terceiros credores, mas como garantia de existência duradoura da sociedade, desempenhando, assim, uma função de produtividade. Só posteriormente, com os crescentes reclamos da classe mercantil, é que o capital social passa a desempenhar também uma função de garantia dos interesses dos credores ${ }^{157}$.

A partir da segunda metade do século XIX, a função garantia do capital assume ares de verdadeiro dogma na literatura jurídica e na evolução legislativa, a ponto de se chegar a desconsiderar outras funções. Tanto assim que ASCARELLI afirma que o conceito de capital social "constitui a cúpula do edifício das normas que visam a proteger os credores sociais." 158 .

Muito se discutiu em período anterior à edição da Lei no 6.404/76 acerca da importância do instituto. REQUIÃO nos dá notícia de palestra do professor LAMY FILHO em que este menciona a postura irresoluta de Bayless MANNING quanto à inutilidade do instituto no que tange a efetiva proteção dos credores, posição muito semelhante a que encontramos hoje na Europa ${ }^{159}$. A crítica do professor MANNING tem que ver, sobretudo, com a possibilidade de fraude de uma cifra que ele chama fruto de inúmeras decisões contábeis, tudo isso sem o conhecimento dos investidores. Contudo, LAMY FILHO parece discordar totalmente desta posição alertando que:

"se a defesa dos credores é incompleta, nem por isso se deve destruí-la, mas antes reforçá-la; se as fraudes contábeis são possíveis, as normas e praxes se vêm reforçando, e não é tão fácil praticá-las porque há sempre o risco da responsabilidade criminal na falência; e, afinal, não nos parece possível prescindir da noção de capital, no estágio atual de nossos usos e práticas comerciais"160

\footnotetext{
${ }^{157}$ LAMY FILHO faz referência ao magistério de ASCARELLI, para quem o capital social surgiu para sanar duas grandes dificuldades do mundo empresarial: a possibilidade do patrimônio ser, no momento de constituição, inferior ao publicado e a possibilidade de que, no decorrer da vida societária,o patrimônio fosse sendo depreciado, desfalcando a garantia dos credores. Cf. ob. cit., p. 181.

${ }^{158}$ In ob. cit. p.61.

${ }^{159}$ In Curso de Direito Comercial, vol. 2, 12ª ed. São Paulo: Saraiva, 1982, pp. 47/48. No mais, em França o capital social é tratado como uma figura "vieillote e depassé", assim segundo GUYON, La mise em harmonie du droit français des societés avec la directive dês communatés européennes sur le capital social, JCP, 1982, I, 3067, nº 1. Já na Itália, "almeno come è attualmente construito, è um mecanismo vechio e arretrato", in SIMONETTO, Azzeramento del capitale ed espulsione del socio. Anatomia di un delito, RS, 1987, p. 757. Citados por .DOMINGUES, ob. cit, p. 14.

${ }^{160}$ In REQUIÃO, Rubens, ob. cit. p. 44.
} 
A doutrina contemporânea vem, no entanto, questionando a real efetividade dessa função. Somos mais por esta tendência o que, em hipótese alguma, deve ser entendido como crítica ao instituto do capital social, per se, mas tão somente à idéia já arraigada de que ele efetivamente tem sentido enquanto mínimo patrimonial para garantia dos credores. E isso não se deve a uma incapacidade técnica intrínseca do instituto, mas à urgência de novos institutos, nomeadamente a Securitização.

A função de garantia ainda é considerada a função mais importante pela literatura jurídica ${ }^{161}$ e visa consagrar os princípios da exata formatação, da intangibilidade e da efetividade ${ }^{162}$, assegurando a integridade do capital social, para que este possa garantir a solvabilidade dos seus créditos.

Assim, a garantia é constituída pelo capital social real, porque pela concepção nominalista do capital social não se é possível compreender o instituto como apto a desempenhar aquela função ${ }^{163}$. Com esse entendimento, o capital social não pode se constituir em uma única garantia dos credores, mas somente poderá ser considerado garantia indireta, porquanto a garantia direta tem que ser prestada em bens.

A preocupação tem, destarte, outro foco, qual seja a de que constem do patrimônio líquido bens de valor pelo menos idêntico à cifra do capital social. Dessa maneira, as dívidas sociais estarão garantidas pela existência de bens no patrimônio com destinação específica e, em caráter suplementar, pelos bens que se destinam à cobertura do da cifra do capital social, que, então, é o mínimo de garantia suplementar para os credores sociais.

Essa preocupação tem que ver com o princípio da intangibilidade do capital social e que preza pela manutenção do seu valor, ou seja, tanto da sua cifra, quanto da sua expressão real.

Tendo em vista que o capital social é constituído por bens, mormente porque somente os bens podem satisfazer o crédito em relação a terceiros, não se deve, para as sociedades anônimas, cogitar acerca da possibilidade de investimento intelectual

\footnotetext{
${ }^{161}$ Entre os autores, COZIAN e VIANDIER,ob. cit., p. 98 e GUYON, ob. cit., pp. 106 e ss.

162 Acerca dos princípios do capital social, PAPINI descreve-os, sucintamente, de maneira que podemos compreendê-los da seguinte maneira: pelo Princípio da Determinação tem-se que o capital social deve ser fixado ou determinado no estatuto de acordo com o art. $5^{\circ}$ da Lei $\mathrm{n}^{\circ}$ 6.404/76; pelo Princípio da Efetividade tem-se que o capital social deve espelhar tanto quanto possível a expressão real do patrimônio social; o Princípio da Fixidez diz com a possibilidade de alteração do capital social somente nas hipóteses legais, em conformidade com o art. $6^{\circ}$ da supracitada lei; o Princípio da Intangibilidade diz com impossibilidade de restituição do capital social aos acionistas. Cf. ob. cit., p. 47.

${ }^{163}$ Cf. COZIAN e VIANDIER, ob. cit., p. 98.
} 
nas companhias, ou seja, a contribuição exclusiva do sócio com know-how, com conhecimentos técnicos, dentre outros.

Isto em razão da limitação de responsabilidade, de modo que os sócios, querendo constituir uma sociedade desse molde, deverão realizar aportes em dinheiro ou com bens apreciáveis em pecúnia, em conformidade com o art. $7^{\circ}$ da Lei n ${ }^{\circ} 6.404 / 76^{164}$.

Segundo DANA-DÈMARET ${ }^{165}$, as críticas feitas em relação ao capital, tomado na sua função de tutela dos credores sociais, de que ele seria um instituto ineficaz, inútil, seriam excessivas. Para ela o excesso existe em razão do equívoco que é considerar o capital social como instrumento de proteção dos credores

Para a autora considerá-lo como garantia dos credores seria engessar a sua função de financiamento da atividade empresarial, porquanto ou ela utiliza os recursos que lhe foram aportados no início, ou procede a um aumento de capital. A única garantia da qual pode se falar é da garantia indireta. Isto é, pode servir como alerta aos administradores de dificuldades vindouras, no momento em que se torna impossível os pagamentos aos credores.

Já em 1931, BERLE e MEANS afirmavam que a natureza do capital estava em processo de mudança de maneira já se pensava na possibilidade de ele ser composto não exclusivamente por bens tangíveis ${ }^{166}$.

Hoje, segundo PENTEADO ${ }^{167}$, a função de garantia do capital social deve ser aprimorada pela imposição de obrigações tanto aos administradores quanto aos acionistas quando da ocorrência do depauperamento do capital.

Já o Decreto $\mathrm{n}^{\text {o }}$ 2.711, de 19/09/1860, “considerava como hipótese de dissolução da sociedade anônima o fato de ela não poder preencher o seu fim”, disciplina alterada pelo Decreto $\mathrm{n}^{\circ} 434$, de 4/7/1891, que a aproximou do art. 336, I do Código Comercial de 1850 onde se lê como causa de dissolução judicial da sociedade "a perda inteira do capital, ou deste não ser suficiente".

\footnotetext{
${ }^{164}$ Assim dispõe o citado dispositivo: “Art. $7^{\circ} \mathrm{O}$ capital social poderá ser formado com contribuições em dinheiro ou em qualquer espécie de bens suscetíveis de avaliação em dinheiro”. De maneira que o art. $8^{\circ}$ exige a avaliação desses bens por perito ou por 3 peritos: “Art. $8^{\circ} \mathrm{A}$ avaliação dos bens será feita por 3 (três) peritos ou por empresa especializada, nomeados em assembléia-geral dos subscritores, convocada pela imprensa e presidida por um dos fundadores, instalando-se em primeira convocação com a presença de subscritores que representem metade, pelo menos, do capital social, e em segunda convocação com qualquer número".

${ }^{165}$ In Le capital social. Paris: Litec, 1989, p.359.

${ }^{166}$ In The modern corporation and private property. New York: Hardcourt, Brace \& World, Inc., 1968, p.45.

${ }^{167}$ Ob. cit., p. 23.
} 
O citado Decreto, no entanto, dispõe, em seu art. 152, que "no caso de perda da metade do capital devem os administradores consultar a assembléia geral sobre a conveniência de uma liquidação antecipada”.

Em 1940, o Decreto-lei $n^{\circ} 2.627$ baniu esses casos de dissolução da legislação brasileira, que, segundo a Lei $n^{\circ}$ 6.404/76 só poderiam existir quando de ação proposta por acionistas representando pelo menos 5\% do capital em hipótese de estar provado que a sociedade já não pode mais preencher o seu fim (art. 206, II, "b").

Segundo PENTEADO ${ }^{168}$, tentativas de reforçar a função de garantia do capital social foram inseridas no anteprojeto de lei sobre as instituições financeiras. Tal documento continha diversas sugestões, entre outras, a criação de um capital mínimo obrigatório, como presente em regimes jurídicos estrangeiros.

$\mathrm{O}$ anteprojeto também continha normas penais tendentes a coibir fraudes verificadas na realização do capital, na avaliação dos bens, na distribuição de lucros fictícios, entre outros.

DOMINGUES propõe uma diferenciação entre o que ele chama de contribuições de mero patrimônio e contribuições de capital. Aquelas, por não serem adequadas à satisfação dos credores da sociedade, não podem ser contabilizadas no capital social.

Já estas, além de serem idôneas a garantir terceiros (podem ser alienáveis, transformáveis em dinheiro ou em outro bem), revestem-se das características de instantaneidade (a prestação, se esgota em um único ato), de produtividade (o bem deve ser adequado à produção) e de perpetuidade (o direito transmitido, deve, ao menos durar enquanto durar a sociedade), sendo, por essa razão, contabilizadas no capital social ${ }^{169}$.

Para as sociedades de capitais, da qual a companhia aberta, objeto desse nosso trabalho, é expoente, tem-se que em razão da completa autonomia patrimonial delas, é necessário um sistema que assegure a solvabilidade dos créditos sociais, o que se pretende ao se propugnar pela existência e realidade do capital social real.

Assim, enquanto na sociedade de pessoas tem-se a garantia prestada pelos sócios, na de capitais essa garantia é real, motivo pelo qual não é admitido, nestas, as entradas de mero patrimônio, mas apenas as de capital.

\footnotetext{
${ }^{168}$ Idem, p. 24.

${ }^{169}$ Cf. ob. cit., p. 143. O autor ainda afirma que a interpretação sistemática da norma portuguesa leva à conclusão de que o que se pretende é que os bens constituintes das entradas dos sócios sejam suscetíveis de avaliação, levando em conta o princípio do going concern, ou continuidade da empresa.
} 
Na União Européia, o art. $7^{\circ}$ da Segunda Diretiva sobre Sociedades ${ }^{170}$ assim dispõe: "O capital subscrito só pode ser constituído por elementos do ativo susceptíveis de avaliação econômica", não significando apenas bens penhoráveis. Segundo a doutrina o entendimento do legislador comunitário foi o de que o know-how e o good-will pudessem constituir a contribuição de um sócio.

\subsubsection{O capital mínimo e a subcapitalização societária}

A função de garantia como contrapartida da limitação da responsabilidade dos sócios parece ser a razão de se exigir um capital mínimo nas sociedades de capitais, tema este que será analisado em maiores detalhes.

COSTA afirma que a sociedade por ações é o sujeito de direito da grande empresa, devendo ter um capital correspondente. Em sendo este pequeno, igualmente será a responsabilidade civil da companhia. Mesmo que a empresa veja seu volume de negócios crescer, a garantia por ela oferecida aos credores manter-se-á reduzida, o que se torna um risco para aqueles que contratam com esta companhia ${ }^{171}$.

Para sanar este tipo de risco, o autor via como necessário o estabelecimento de um piso para a constituição das sociedades anônimas. No entanto, o legislador de 1976 decidiu por não fazê-lo, alegando que não pretendia reservar tal modelo societário às grandes empresas e que a maior proteção aos créditos se daria não pelo estabelecimento de um capital mínimo, mas pela publicidade da maior parte dos atos societários num modelo aberto de companhia.

Nesse sentido MARTINS ${ }^{172}$ também admite que embora não seja estipulado legalmente um mínimo de capital social para as sociedades anônimas, isto seria desejável, em virtude do grande porte dos empreendimentos que são esperados de uma companhia com esse formato.

No entanto, sabe-se que alguns ramos de atividade exigem que as sociedades sejam constituídas com um capital mínimo, por terem porte massivo, dirigido a grande número de pessoas. Entre estes setores destaca-se o bancário e o securitário.

\footnotetext{
${ }^{170}$ Obtido a partir do site http://eur-lex.europa.eu/LexUriServ/LexUriServ.do?uri=CONSLEG:1977L0091:20070101:PT:PDF, acessado em 23/09/07.

${ }^{171}$ In ob. cit., p. 131.

172 In ob. cit., p. 54.
} 
A Lei $n^{\circ} 6.404 / 76$ traz a possibilidade de serem constituídas sociedades anônimas de pequeno ou de médio porte (apesar da sofisticação da norma, que remete especialmente a empresas de grande porte). Na opinião de MARTINS ${ }^{173}$, companhias deste tamanho deveriam se organizar como limitadas, não como sociedades anônimas, pois o primeiro modelo atende justamente a esta faixa das atividades comerciais.

Quem defende o modelo de sociedade anônima para empresas de pequeno ou de médio porte alega que a legislação sobre sociedades por quotas é antiquada. Diz o autor que o ideal, portanto, seria a modificação dessa legislação, e não a permissão para tais empresas tomarem o formato de sociedade anônima, pois, devido ao fato de que empresas deste porte, em sua maioria, são sociedades fechadas, elas acabam por somente se beneficiar das vantagens do modelo, sem, em contrapartida, oferecer mobilidade ao mercado mobiliário.

Com efeito, o capital mínimo refere-se ao dever dos sócios em realizar contribuições, com as quais adquirem tal status. Assim, fica claro que no patrimônio da sociedade sempre constará, no mínimo, o direito às contribuições que os sócios realizaram, motivo pelo qual a sociedade terá sempre um patrimônio mínimo.

BATALHA assim o define:

“capital mínimo é o capital realizado indispensável para o exercício de determinado gênero de atividades, como, por exemplo, para as atividades bancárias e as atividades de seguro" 174

Como afirmado anteriormente, a exigência de capital mínimo foi excluída da lei societária de 1976, pois seus criadores pensavam que tal disposição só tinha aplicação para a disciplina das grandes sociedades. Entretanto, os defensores dessa exigência dizem que, sem ela, os fundadores das sociedades poderiam, no limite, criar uma sociedade sem capital, sem responsabilidade dos sócios e sem regulamentação rigorosa, o que seria contrário à proteção pretendida pelo legislador.

No entanto, não obstante as excepcionais regras especiais relativas a companhias que se dedicam a determinadas atividades, o art. 19, $\S 6^{\circ}$ da Lei $n^{\circ}$ 6385/76 permite à CVM exigir, quando uma companhia aberta desejar fazer o registro de emissão pública de ações, que esta tenha determinado capital mínimo ${ }^{175}$.

\footnotetext{
${ }^{173}$ In ob. cit., pp. 55/56.

${ }^{174}$ Ob. cit., p. 112.

175 "§ $6^{\circ}$ - A Comissão poderá subordinar o registro a capital mínimo da companhia emissora e a valor mínimo da emissão, bem como a que sejam divulgadas as informações que julgar necessárias para proteger os interesses do público investidor."
} 
De fato, o capital mínimo funciona efetivamente, mas tem por função própria a escolha do tipo societário a ser adotado. Funciona, ainda, de forma suplementar como garantia dos credores. A tendência existente nos países europeus, segundo PENTEADO $^{176}$, é a de redução da cifra mínima do capital social em razão dos grandes conglomerados atuarem mediante pequenas empresas e, em estudo sobre o aumento do capital social, nota que:

"na Itália, com a adoção do regime do capital mínimo, a redução do capital abaixo desse piso constitui causa de dissolução da companhia (Código Civil, art. 2.448, n. 4), salvo se a assembléia geral não optar pelas seguintes alternativas: a) redução e contemporâneo aumento até o limite legal ou b) transformação da companhia em outro tipo societário (art. 2.447). Verificada a ocorrência dessa causa de dissolução, os administradores não podem realizar novos negócios, sob pena de incorrer, quanto a estes, em responsabilidade solidária e ilimitada (art. 2.449) ${ }^{177}$."

A questão do capital social mínimo traz o problema da adequada capitalização da sociedade e da responsabilidade do administrador por isso, mas, no dizer de Sylvio MARCONDES ${ }^{178}$ o que importa para os credores é que o valor do passivo nunca exceda o do ativo, evidenciando o caráter de garantia atribuído ao instituto.

COMPARATO $^{179}$, com base na teoria da desconsideração da personalidade jurídica, observa que na Alemanha e nos Estados Unidos imputa-se ao administrador a responsabilidade pelos débitos sociais no caso de insuficiente capitalização da empresa, já que tal ato constituiria um risco criado deliberadamente contra terceiros. Na Itália, por sua vez, os tribunais têm entendido que a insuficiente capitalização da empresa importa em nulidade do ato constitutivo da sociedade, por impossibilidade de cumprimento do objeto.

A exigência de capital social mínimo pode ser encarada sob várias óticas, dentre as quais uma parte da doutrina que a entende como correspondente à limitação da responsabilidade para garantia dos credores.

\footnotetext{
${ }^{176}$ Ob. cit., p. 26.

${ }^{177}$ Idem, ibidem.

${ }^{178}$ In Ensaio sobre a sociedade de responsabilidade limitada, tese. São Paulo, 1940, p. 124. Citado por PENTEADO, ob. cit., p. 19.

${ }^{179}$ In $O$ poder de controle na sociedade anônima. $4^{\mathrm{a}}$ ed. Rio de Janeiro: Forense, 2005, pp. 343/346.
} 
Diversos autores afirmam que o capital social mínimo, surgido com a limitação da responsabilidade, garante um mínimo de idoneidade, de seriedade por parte do ente jurídico $^{180}$.

DOMINGUES $^{181}$ afirma que o capital mínimo, no entanto, não se mostra nem necessário e nem adequado para remediar a limitação da responsabilidade. Prova dessa desnecessidade é o fato de o direito saxão desconhecê-lo, embora exista, conforme o artigo $6^{\circ}$ da Segunda Diretiva sobre Sociedades ${ }^{182}$, a exigência de que todos os países pertencentes à Comunidade Européia estipulem um capital mínimo para as sociedades anônimas. Além do que, para o Autor, há a possibilidade do valor do capital mínimo poder ser depreciado em virtude de processo inflacionário.

Uma crítica que pode ser feita a essa exigência é a restrição injustificada à liberdade contratual, impedindo a criação de pequenas empresas, pois a estipulação do capital pode ser irrisória para alguns empreendimentos e exorbitante para outros. Daí pode ser entendido que o capital mínimo nada mais é que um instrumento de seleção do tipo social a adotar. Para uma empresa média, por exemplo, outras razões além da exigência de capital mínimo determinarão o tipo societário a ser utilizado.

A sociedade anônima exige uma estrutura organizacional mais pesada e tem uma disciplina mais complexa e mais onerosa, principalmente no que respeita à matéria de organização, publicidade dos atos e fiscalização. A adoção desse tipo será justificada quando se pretenda obter recursos no mercado de capitais.

Os ordenamentos que adotam o capital mínimo costumam exigir uma cifra mais elevada para a constituição de sociedades por ações. DOMINGUES nota a respeito da solução brasileira estabelecida na lei sobre as sociedades por ações:

\footnotetext{
${ }^{180}$ Em Portugal não se fez nenhuma exigência desse nível para as S.A. até a revogação do Código Comercial em 1986. Isso se devia à idéia de que as S/A serviam sempre aos grandes empreendimentos, o que tornava desnecessária a exigência de capital mínimo. Só quando do surgimento da limitada (lá sociedade por quotas), em que se garantia a limitação da responsabilidade para as atividades de menor monta é que se torna obrigatória a existência de um capital mínimo.

${ }^{181}$ In ob. cit., p. 149.

${ }^{182}$ Assim dispõe o referido dispositivo; "Art. $6^{\circ}$ 1. Para a constituição da sociedade ou para a obtenção da autorização para iniciar as suas atividades, as legislações dos Estados-membros devem exigir a subscrição de um capital mínimo que não pode ser fixado em montante inferior a 25000 A3ECUS”. Observe-se que essa unidade monetária é uma unidade de conversão estipulada na Decisão No $^{\circ}$ 3289/75/CECA da Comissão, de 18/12/75, relativa à definição e à conversão da unidade de conta a utilizar nas decisões, recomendações, pareceres e comunicados nos domínios do Tratado que institui a Comunidade Européia do Carvão e do Aço, disponível no site:

http://eur-

lex.europa.eu/smartapi/cgi/sga_doc?smartapi!celexplus!prod!CELEXnumdoc\&numdoc=31975S3289\&lg=pt, consultado em 23/09/07.
} 
"que deliberadamente não fixou qualquer capital social mínimo para este tipo social. Tratou-se de uma opção política legislativa consciente, porquanto, conforme se pode ler no Preâmbulo, não se quis reservar o modelo para as grandes empresas, dado que 'embora muitas das pequenas companhias existentes no país pudessem ser organizadas como sociedades por quotas, de responsabilidade limitada, não há interesse em limitar arbitrariamente a utilização da forma da companhia que oferece maior proteção ao crédito devido à publicidade dos atos societários e das demonstrações financeiras" 183.

No Brasil a opção legislativa de não exigir capital mínimo para as sociedades por ações encontra-se explicitada na Exposição de Motivos da Lei no 6.404/76 entendendo o legislador não haver interesse em limitar arbitrariamente a utilização da forma de companhia, que oferece maior proteção ao crédito devido à publicidade dos atos societários e das demonstrações financeiras.

Como nas sociedades de capitais, tipo abordado neste estudo, a responsabilidade dos sócios é limitada ao montante da parcela do capital social que possuem, o risco da atividade empresarial que excede aquele limite acaba sendo transferido a terceiros (fornecedores, trabalhadores, bancos e aqueles que por alguma razão fizeram empréstimos à empresa). Entretanto, nem todos os credores se encontram em condições similares. Há os credores fortes, entre os quais grandes fornecedores, bancos empresas de financiamento que logram garantir seus créditos com garantias pessoas ou reais prestadas pelos sócios; há, por outro lado, credores, como pequenos fornecedores e trabalhadores, que não conseguem obter tais garantias. Fácil, assim, perceber que os credores fortes conseguem, dessa maneira, uma responsabilidade ilimitada por parte dos sócios.

Assim, nas sociedades de capitais, tendo em vista a limitação da responsabilidade dos sócios, o regime do capital social, se chega a cumprir de garantia para terceiros, não o faz de modo plenamente satisfatório.

Se o capital social, em termos proporcionais, for menor que o passivo, na hipótese de um exercício ruim o ativo ficará mais baixo que o passivo, ocasionando perdas que minam o capital social, retirando toda a garantia de terceiros. Por outro lado, se o ativo

${ }^{183}$ Cf. DOMINGUES, ob. cit., pp. 151/152. 
supera em muito o passivo, pode-se estar diante da hipótese segundo a qual se está retendo bens no ativo em quantidades muito superiores as necessidades dos terceiros.

A eficácia à garantia de terceiros (e também a função de produtividade que se aponta ao capital), torna, assim, necessária a adequação entre capitais próprios e alheios, para que o capital social nunca fique muito abaixo do passivo, nem muito acima dele, o que, em última instância, geraria também uma sub-remuneração dos sócios.

No entanto, percebe-se que o regime jurídico do capital social não é capaz de desempenhar satisfatoriamente a função de garantia dos credores porque não consegue a adequação do valor do capital social com o objeto social. Talvez fosse mais adequada a adoção do sistema norte-americano, que estipula um coeficiente de solvência, isto é, uma relação mínima entre capitais próprios e alheios, em que se determina a distribuição de bens aos sócios, apenas quando o ativo, líquido, superasse em determinado valor, o passivo.

Outras legislações, segundo estudo do autor português, buscam estabelecer mecanismos de verificação dessa adequação. Nesse sentido a lei egípcia de 1954 que traz no art. $6^{\circ}$ a exigência de capital mínimo para as S/A, para que este seja compatível com a realização do objeto social.

$\mathrm{Na}$ Bélgica, até metade da década de 70 , não se fazia qualquer exigência legislativa de capital mínimo. Entretanto, o legislador trouxe na reforma das Lois coordonnées a exigência de elaboração de um plano financeiro justificativo do montante do respectivo capital social, plano este que fica registrado junto ao órgão que celebra a escritura de constituição da sociedade (artigos 29 ter e 120 ter).

Nos Estados Unidos, por sua vez, o California Corporation Code, de 1975, ao invés de estabelecer um conceito de capital social, faz referência ao um denominado coeficiente de solvência que impede a distribuição de bens aos sócios quando inexista mínima relação entre patrimônio líquido e passivo, consagrando-se, em verdade, a intangibilidade do patrimônio líquido, o que, embora não resolva o problema da subcapitalização originária, procura assegurar a congruência do capital social ao longo da vida da sociedade.

Observe-se que, segundo as legislações analisadas, não é qualquer subcapitalização que dará causa à nulidade do contrato social, mas tão-somente aquela que importe em clara impossibilidade do objeto, não bastando que seja este difícil de se realizar. Não basta ainda, como esclarecem alguns autores portugueses, que seja impossível para o promitente, não o sendo para outra pessoa, devendo constituir-se em 
uma impossibilidade absoluta e geral ${ }^{184}$. Não fosse assim, estar-se-ia permitindo uma ingerência desautorizada por parte dos órgãos estatais na liberdade econômica dos particulares.

Conforme afirmado, a nossa legislação não contempla a exigência de um capital mínimo, razão pela qual seria pertinente indagar se isso indicaria uma liberdade ampla na fixação do capital social.

Sabe-se que nosso sistema permite a livre escolha do objeto social e da estrutura social adotada, não restringindo o tipo "sociedade anônima" aos investimentos de grande soma. Isso não obstante, deve ser exigido dos sócios que, para o desenvolvimento de suas atividades, procedam à compatível capitalização da companhia, em respeito ao princípio da adequação do capital social.

$\mathrm{Na}$ hipótese da companhia não possuir capital apto a implementar adequadamente a atividade a que se propõe, ou ainda apto a suportar os riscos que essa atividade gera, a companhia será considerada como em situação de subcapitalização.

Gustavo Saad DINIZ ${ }^{185}$, em obra específica sobre o tema, contrapõe duas formas de subcapitalização: a nominal e a material. Para o autor, entende-se por subcapitalização nominal aquela na qual o sócio se torna credor da sociedade quando empresta dinheiro à esta para que ela cumpra o seu objeto social. Nesse caso, os sócios passam a concorrer com os demais credores sobre o acervo patrimonial da companhia, na hipótese de crise desta.

O efeito pernicioso dessa situação está em que o sócio pode ter a vantagem de determinar a preferência do adimplemento do seu crédito. Ocorrerá, então, o rompimento da intangibilidade do capital social, porquanto o sócio tentará resgatar para si o patrimônio restante de uma sociedade necessitada de capital.

No caso da subcapitalização material, o capital aportado à sociedade é totalmente incoerente frente à atividade que deveria exercer, de maneira que há transferência dos riscos que os sócios deveriam correr (os riscos do empreendimento) para os credores. Nesse caso, DINIZ dirá que há uma insuficiência de capitais próprios e a utilização de capitais de terceiros em desequilíbrio com os capitais próprios ${ }^{186}$.

\footnotetext{
184 DOMINGUES, Manuel de Andrade. Facto Jurídico, em especial Negócio Jurídico. Teoria Geral da Relação Jurídica. Coimbra, 1987. Vol. II, pp. 331 e ss. Citado por DOMINGUES, ob. cit., p. 180

${ }^{185}$ In Subcapitalização societária. Tese apresentada à Faculdade de Direito da Universidade de São Paulo como requisito para obtenção do título de Doutor, 2007, pp. 155 e 156.

${ }^{186}$ Idem, pp 175/177.
} 
E no que respeita a esse assunto é pertinente a discussão acerca da responsabilidade pessoal dos sócios. São várias as opiniões a esse respeito, havendo aqueles que entendem pela não responsabilização dos sócios, porquanto a responsabilidade desses é limitada apenas pelo valor que aceitam subscrever.

SALOMÃO FILHO, inspirado na doutrina alemã, distingue dois tipos de subcapitalização: a simples, representando os casos menos evidentes, em que se deve perquirir o elemento volitivo dos sócios no momento da capitalização da companhia e a qualificada em que a subcapitalização é ostensiva, denotando que a sociedade não tem condições de desenvolver o objeto social. Afirma o autor que o sócio não deve responder por uma eventual subcapitalização da sociedade precisamente pelo fato de que, em razão de inexistir a exigência de um capital mínimo, não há parâmetro para estabelecer o que seria uma capitalização adequada, objetivamente. A responsabilização só ocorreria no caso de subcapitalização qualificada. ${ }^{187}$

No que respeita à hipótese de os sócios, estando a companhia em débil situação financeira, emprestarem dinheiro à sociedade, ao invés de fazerem reforços ao capital social, SALOMÃO entende que tais empréstimos deveriam ser contabilizados na conta capital social ${ }^{188}$.

Fábio Konder COMPARATO entende que a subcapitalização é sim um fato imputável aos sócios, mais especificamente ao controlador, porquanto é dever dele prover o capital adequado para que a companhia exerça suas atividades. Com efeito, afirma o autor que não compete a ele fazer empréstimos à sociedade em momentos de crise, e sim proceder ao aumento de capital, subscrevendo novas ações, do contrário ele apenas estará se furtando ao risco do investimento ${ }^{189}$.

Ora, certo é que a personalidade jurídica, esta armadura, conforme explicamos acima, é um privilégio concedido pela ordem jurídica a bem do desenvolvimento dos empreendimentos mercantis, de maneira que não pode colocar em risco o crédito, importando em óbices aos credores. É esse o compromisso que os sócios assumem ao constituírem uma sociedade anônima, isto é, fazer uso da personalidade jurídica para por em prática objetivos empresariais, e não meramente para se furtarem ao cumprimento das regras jurídicas.

\footnotetext{
${ }^{187}$ In O Novo Direito Societário. São Paulo: Malheiros, 2002, pp. 90/91.

${ }^{188}$ Idem, p. 91.

${ }^{189}$ In ob. cit., p. 370.
} 
Daí a importância do capital social: não se podem admitir sociedades despreparadas para o trato comercial, porquanto insuficientemente providas de capitais. Daí também a necessidade de responsabilização dos sócios no caso desse desajuste, conforme teremos a oportunidade de observar no capitulo especifico sobre a desconsideração da personalidade jurídica.

\subsubsection{A função política}

A pulverização do capital social, o fato dele estar fracionado em pequenas parcelas representadas por ações, possibilita a sua dispersão por um grande número de pessoas levando à sua socialização. É precisamente este fenômeno da pulverização do capital social que leva à discussão entre propriedade de títulos e poder de controle no âmbito das sociedades anônimas, colocando a função de socialização do capital social sob o plano externo, em razão de os pequenos acionistas serem tratados quase como terceiros, já que, em tese, não desejam tomar parte no gerenciamento dos negócios da sociedade, mas apenas receber remuneração pelo capital investido.

Já na ótica das relações internas, a discussão entre a propriedade de títulos e poder de controle leva o capital social a ter, também, a função de atribuição da qualidade de sócio a uma pessoa. Assim, só há sociedade se existirem sócios, e estes só adquirem tal status quando realizam contribuições ao capital social da companhia a companhia, contabilizadas no capital social, e que corresponderão a sua participação social.

Nesse sentido, é o capital social quem atribui aos sócios tal qualidade, sendo por esta razão não apenas funcional, mas fundamental relativamente à sociedade. $\mathrm{O}$ capital social consiste, em suma, em elemento indispensável para a determinação de certos direitos e deveres dos sócios. Assim que os sócios participam, a princípio, nos lucros e nas perdas, em medida proporcional à sua participação social e, da mesma maneira, com os votos, determinados a partir da posição de sócio em relação ao capital social.

E já que o capital social define as relações de poder dentro da sociedade, por estas dependerem da participação de cada sócio, as deliberações da Assembléia Geral dependem do número de votos de cada sócio, votos estes que, em última instância, também dependem da participação no capital social.

Não por outra razão são estipuladas na Lei $n^{\circ}$ 6.404/76 determinadas prerrogativas aos sócios, na proporção da participação que estes detém naquele capital. 
Assim, de acordo com determinadas porcentagens, é lícito a um ou mais sócios realizarem determinadas atividades.

Desse modo, o titular (ou titulares) de mais do que 50\% das ações com direito de voto, no caso de eleição de conselheiro pelo sistema de voto múltiplo em que os titulares de ações ordinárias ou preferenciais exercem a prerrogativa de eleger conselheiro, terá (terão) o direito de eleger conselheiros em número igual ao dos eleitos pelos demais acionistas, mais um, independentemente do número de conselheiros que o estatuto tenha definido para a composição do órgão (art. $141 \S 7^{\underline{0}}$ ).

Os titulares de ações de emissão de companhia aberta com direito a voto, que representem, pelo menos, $15 \%$ do total das ações com direito a voto e os detentores de ações preferenciais sem direito a voto ou com voto restrito, representativas de $10 \%$ do capital social, terão direito, respectivamente, a eleger e destituir um membro e seu suplente do conselho de administração, em votação em separado na Assembléia Geral (art. 141, § $4^{\mathrm{o}}$, I e II).

Detendo 5\% do capital social é possível que o acionista:

a) exija, judicialmente, a exibição por inteiro dos livros da companhia diante da prática de atos violadores de lei, ou de suspeita do cometimento de irregularidades graves (art. 105, caput).

b) convoque Assembléia Geral quando os administradores não atenderem, no prazo de 8 (oito) dias o pedido de convocação que tiverem apresentado (art. 123, parágrafo único, “c”).

c) seja convocado para comparecimento em Assembléia Geral por carta registrada ou telegrama, expedidos com antecedência mínima de 8 dias (primeira convocação) ou 5 dias (segunda convocação) nas companhias fechadas e com antecedência mínima de 15 dias (primeira convocação) ou 8 dias (segunda convocação) nas companhias abertas. Essa prerrogativa precisa ser solicitada por escrito e se não cumprida dá direito ao acionista de receber indenização dos administradores em caso de algum prejuízo sofrido $\left(\right.$ art. $\left.124, \S 3^{\circ}\right)$.

d) exija que o administrador revele em Assembléia Geral "o número dos valores mobiliários de emissão da companhia ou de sociedades controladas, ou do mesmo grupo, que tiver adquirido ou alienado, diretamente ou através de outras pessoas, no exercício anterior; as opções de compra de ações que tiver contratado ou exercido no exercício anterior; os benefícios ou vantagens, indiretas ou complementares, que tenha recebido ou esteja recebendo da companhia e de sociedades coligadas, controladas ou do 
mesmo grupo; as condições dos contratos de trabalho que tenham sido firmados pela companhia com os diretores e empregados de alto nível; quaisquer atos ou fatos relevantes nas atividades da companhia" (art. 157, § $1^{\circ}$ ).

e) promova ação de responsabilidade por danos causados contra o administrador quando a Assembléia decide não o fazer (art. 159, § 4º).

f) exija informações do Conselho Fiscal nas matérias de sua competência (art. 163, § $6^{\circ}$ ).

g) proponha a ação de dissolução da companhia quando provado que esta não atingiu seu fim (art. 206, II, “b”).

h) proponha ação de responsabilidade por perdas e danos, em caso de desrespeito ao texto dos artigos 116 e 117 contra sociedade controladora daquela da qual é acionista (art. 246, §1" , “a”).

Detendo um décimo das ações com direito a voto o acionista pode:

a) pedir à Assembléia Geral a instalação do Conselho Fiscal quando este não for permanente ( $\left.\operatorname{art} .161 \S 2^{\circ}\right)$.

b) requerer, na eleição dos conselheiros, a adoção de processo de voto múltiplo, pelo qual atribui-se à ação tantos votos quanto sejam os membros do conselho, sendo garantido o acionista o direito de cumular os votos num candidato só, ou distribuílos entre os outros (art. 141).

A Comissão de Valores Mobiliários, utilizando-se da prerrogativa inserta no art. 291 da lei societária ${ }^{190}$, editou a Instrução CVM n ${ }^{\circ}$ 165/91 (alterada pela Instrução CVM n ${ }^{\circ} 282 / 98$ ) cujo art. $1^{\text {o }}{ }^{191}$ apresenta a tabela a seguir reduzindo a percentagem mínima em função do valor do capital social:

\footnotetext{
190 “Art. 291. A Comissão de Valores Mobiliários poderá reduzir, mediante fixação de escala em função do valor do capital social, a porcentagem mínima aplicável às companhias abertas, estabelecida no art. 105; na alínea $c$ do parágrafo único do art. 123 ; no caput do art. 141 ; no $\S 1^{\circ}$ do art. 157 ; no $\S 4^{\circ}$ do art. 159 ; no $\S 2^{\circ}$ do art. 161; no $\S 6^{\circ}$ do art. 163; na alínea $a$ do $\S 1^{\circ}$ do art. 246; e no art. 277”".

191 "Art. $1^{\mathbf{0}}$ Em função do valor do capital social da companhia aberta, é facultado aos acionistas representantes do capital social com direito a voto, esteja ou não previsto no estatuto, requerer a adoção do processo de voto múltiplo para a eleição dos membros do Conselho de Administração, observada a tabela a seguir:"
} 


\begin{tabular}{|c|c|}
\hline $\begin{array}{c}\text { Intervalo do Capital Social } \\
(\mathrm{R} \$ 1)\end{array}$ & $\begin{array}{c}\text { Percentual Mínimo do Capital Votante } \\
\text { para Solicitação de Voto Múltiplo \% }\end{array}$ \\
\hline 0 a 10.000 .000 & 10 \\
\hline 10.000 .001 a 25.000 .000 & 8 \\
\hline 25.000 .001 a 50.000 .000 & 7 \\
\hline 50.000 .001 a 75.000 .000 & 6 \\
\hline 75.000 .001 a 100.000 .000 & 5 \\
\hline acima de 100.000 .001 & \\
\hline
\end{tabular}

Detendo 5\% do capital votante, ou das ações com direito a voto, é possível ao acionista:

a) proceder à convocação da Assembléia para instalação do Conselho Fiscal, quando os administradores não atenderem, no prazo de oito dias, o pedido de convocação anteriormente feito (art. 123, parágrafo único, “d”).

b) pedir o funcionamento de conselho fiscal de companhia filiada ao grupo. Nesse caso o acionista não pode ser controlador (art. 277).

Detendo 5\% das ações sem direito a voto é possível ao acionista:

a) proceder à convocação da Assembléia para instalação do Conselho Fiscal, quando os administradores não atenderem, no prazo de oito dias, o pedido de convocação anteriormente feito (art. 123, parágrafo único, “d”).

b) pedir à Assembléia Geral a instalação do Conselho Fiscal quando este não for permanente ( $\left.\operatorname{art} .161 \S 2^{\circ}\right)$.

c) pedir o funcionamento de conselho fiscal de companhia filiada ao grupo (art. 277).

O detentor de meio por cento do capital social pode solicitar relação de endereços dos acionistas desde que para atendimento dos fins estabelecidos no parágrafo $1^{\circ}$ do art. 126 (constituição de procurador para representação em Assembléia) (art. 126, § $3^{\circ}$ ). 


\subsubsection{A função de produtividade}

Por fim, na medida em que o capital social, na sua acepção de capital real, objetiva congregar os meios aptos ao desenvolvimento do objeto social, acaba por desempenhar uma função que se denomina de produtividade. Isso a consagrar a idéia de que o capital social não tem somente a função de garantia, mas também outras, dentre as quais a de avaliar a situação econômica da sociedade no que tange à sua capacidade de gerar lucro.

É do confronto entre capital social e patrimônio líquido que se avaliará a saúde da empresa, através da verificação de seus resultados, lucros ou perdas na sua exploração.

Daí, embora alguns autores advirtam que para o capital social se revelar um meio totalmente idôneo para a avaliação da situação econômica da empresa, seria necessária estabilidade monetária (já que a flutuação da moeda traz como consequência o fato de a diferença entre capital social e patrimônio não advir de um verdadeiro lucro, mas da diminuição da cifra do capital social), o capital social importa em parâmetro essencial a avaliação econômica que se queira fazer, a qualquer momento da vida social.

Ainda assim, não obstante existam críticas em relação a essa função do capital social nominal, este, enquanto cifra fixa, é um elemento sério e idôneo à apreciação da viabilidade econômica da empresa, dado a variabilidade dado patrimônio social. Assim conclui DOMINGUES:

“(...) a figura do capital social justifica-se, porque, através das diversas medidas legislativas direcionadas à sua tutela, serve pelo menos como indício, como ponto de referência da robustez financeira da empresa, constituindo, desse modo, um elemento no qual terceiros podem basear as relações de crédito (...) Por outro lado, a figura do capital social justifica-se ainda porque ele não desempenha unicamente uma função de garantia mas variadíssimas outras funções"192.

Embora a função de garantia tenha tomado, na literatura jurídica clássica, o lugar de função precípua do capital, hodiernamente diz-se que o capital social exerce

${ }^{192}$ Cf. DOMINGUES, ob. cit., p. 183. 
parcialmente uma função de produtividade e reflexamente uma função de garantia. Tal doutrina considera que a grande garantia da empresa está na sua capacidade de crédito, capacidade esta que deriva da sua produtividade, que, por isso, deve ser protegida ${ }^{193}$.

Observar o capital social desde o ponto de vista da sua função de garantia a terceiros credores importa em considerar que aquele só poder ser constituído por bens que efetivamente garantam terceiros, ou seja, bens penhoráveis. Observá-lo desde o ponto de vista da função de produtividade significa aceitar que as contribuições dos sócios possam ser efetivadas por quaisquer bens, desde que idôneos à realização do objeto social.

\subsection{Lições de Direito Comparado}

\subsubsection{O desenvolvimento do instituto nos Estados Unidos}

A formação do conceito de capital social remete diretamente à história do século XIX. Segundo MANNING a compreensão do conceito só faria sentido naquela época, embora não se deva exigir muita clareza nas práticas mercantis da época ${ }^{194}$.

Bem assim, no final desse século, o capitalismo industrial estava dando seus primeiros passos, o capitalismo financeiro começava seu alvorecer e os princípios contábeis não eram muito clarificados: poucos eram os que conheciam o sistema das partidas dobradas. Daí que as análises judiciais e mesmo empresariais sobre assuntos como valor nominal, capital social, subscrição de ações, entre outros, careciam de aparato técnico e de coerência.

Em verdade, faltavam conhecimentos e ferramentas específicas para que os profissionais da época lidassem com tais assuntos, por isso, afirma MANNING, não se pode pretender estudar a matéria tendo como referência aquilo que se discutia no século $\mathrm{XIX}^{195}$.

Tentou-se desenvolver, como modo de garantia a terceiros e mesmo como forma a permitir que a sociedade cumprisse o seu objetivo, a exigência de um capital mínimo. Mas este se mostrou impraticável e até mesmo antiético. Continuou apenas

\footnotetext{
${ }^{193}$ Cf Idem., p. 190.

${ }^{194}$ In Legal capital. $3^{\text {a }}$ ed. Westbury: Foundation Press, 1990, p. 20.

${ }^{195}$ In verbis: "In large degree therefore, it is an error to attempt a precise reconstruction of the way in which the nineteenth century looked at such matters. The truth is that there simply was no coherent view of these matters in the nineteenth century" in idem, ibidem.
} 
exigido naqueles ramos de atividades nos quais a subcapitalização seria prejudicial, sobretudo ao interesse público, isto é, aos bancos, às companhias de seguros, entre outros.

É bom que se diga que até recentemente os estatutos da companhia ainda previam um capital mínimo para que então a companhia pudesse iniciar suas atividades. Mas toda essa provisão era pro forma, de maneira que se encontravam legislações que traziam como limite mínimo para capitalização da empresa o valor de US\$1,000. Daí que toda essa legislação não oferecia proteção nenhuma aos credores.

Sabe-se que foi a pressão dos credores que fez surgir a criação de uma proteção efetiva para os mesmos. Tal sistema foi consubstanciado na disciplina do capital social. No entanto, a questão essencial sempre foi (e sempre será) saber quanto dinheiro a empresa vai ter ao longo da sua vida, e não quanto ela terá no seu começo, isto é, interessa que seja demonstrada a solvabilidade da empresa durante sua atividade.

O modelo desenvolvido no século XIX trazia ao juiz a possibilidade de que ele soubesse quanto dinheiro os sócios tinham colocado na empresa. Em verdade, a constituição da sociedade se dava da seguinte maneira: um empreendedor, chamado promotor (promoter), que havia idealizado algum negócio, procurava pessoas que estivessem interessadas em investir nesse negócio. Aqueles que se interessassem pelo negócio deveriam firmar um acordo com o empreendedor de que subscreveriam as ações da nova companhia, assim que encontrados o número suficiente de investidores, se, é claro, a companhia criada fosse exatamente aquela que constava do "prospecto" original.

Esse modelo trazia consigo o conceito de valor nominal das ações. Isto porque inevitavelmente o investidor fazia a conta de quanto dinheiro investiria para receber um relativo número de ações. De maneira que nenhum dos potenciais investidores iria aceitar adquirir ações por valor outro que não o valor nominal.

Se o empreendedor tivesse sucesso em angariar os investidores necessários com as promessas de subscrição, poderia então receber a carta de autorização da autoridade competente de cada Estado. A partir daí todos os investidores se reuniriam para eleger os administradores, criar um estatuto, seria então recolhida a contribuição de cada um, sendo entregue, em troca, certificados correspondentes ao número de ações de cada um, constando deles o valor nominal de cada ação.

O valor nominal passa, então, a ser entendido como o valor que o acionista deveria pagar por sua ação. Ações sem correspondente valor nominal ficaram conhecidas como ações sem lastro 
Mas, vai garantir MANNING ${ }^{196}$, que toda essa maquinaria não foi suficiente a realmente trazer efetiva garantia nem aos credores, nem aos negócios. Segundo ele todo o sistema apenas margeia a tutela das classes ou grupos de acionistas com interesses conflitantes. E no que tange aos credores o sistema não afasta as três preocupações principais, quais sejam, erosão do caixa da empresa, incursão da empresa em mais débitos, e criação de um crédito de classe superior.

A intenção do sistema é assegurar que todo acionista contribua com bens para a sociedade, assim como assegurar que eles não redistribuirão tais bens entre si.

Afirma o Autor que embora não existam estudos empíricos, o que acontece é que o sistema de capital social oferece pouca ou nenhuma proteção aos credores. E ele enumera as seguintes razões ${ }^{197}$ :

1. O sistema é incompleto. Tudo é resultado de uma série de operações contábeis, de maneira que sem as regras contábeis o sistema se torna vazio.

2. Os acionistas têm todo o controle para alteração do estatuto no que concerne ao capital social e falta isso para os credores. Isto é falta participação dos credores para a realização de mudanças no estatuto.

3. A cifra do capital social é um número arbitrário, sem relação com qualquer fato econômico relevante para o credor. Ao credor não interessa saber qual foi o valor nominal da ação emitida na constituição da companhia, e embora ele acredite que as ações de valor nominal mais alto sejam as mais seguras, sabe que a cifra do capital social é puramente ficcional.

4. O sistema não tem um fundamento que o explique. Não há razão pela qual alguém usará uma cifra meramente contábil para estabelecer os limites de distribuição de dividendos aos acionistas. E aquilo que importa ao credor saber fica de fora.

5. A concepção de crédito muda para o credor e para o sistema do capital social: assim que para o sistema um débito com vencimento longo é tratado da mesma maneira que outro de vencimento curto. Nas palavras de MANNING: "it is assumed by the statute that creditors of today and tomorrow care about sales of stock made years before. They don't. And so forth." 198

6. Grandes debates são produzidos acerca dos conceitos contábeis e a vida econômica. Advogados e contadores se digladiam discutindo coisas como o modo correto

\footnotetext{
${ }^{196}$ In ob. cit., p. 91.

${ }^{197}$ In ob. cit., pp. 91/97.

${ }^{198}$ Idem, p. 95.
} 
de subscrição de ações, acordos de aquisição, fusões, cancelamento de ações em tesouraria, exercício de opções, liquidação de preferências, e outros tantos assuntos, sem que isso leve a algum resultado relevante.

7. Há ainda outro problema: as empresas não aplicam com seriedade as regras do sistema e isso se verifica em estatutos que prevêem a distribuição de dividendos aos sócios ainda que o capital social esteja seriamente prejudicado. Quando o dividendo é pago a partir do excedente do capital (capital surplus) faz-se uma arquitetura jurídica com ações de baixo valor nominal, criando assim um superávit contábil que permite a distribuição.

Muitos estatutos permitem o pagamento de dividendos aos acionistas pela forma "against reduction surplus", uma forma de superávit fácil de ser criada. Outros estatutos permitem que sejam entregues bens da empresa a acionistas que adquirirem ações dela. É como se o sistema permitisse que a raposa cuidasse das galinhas.

Ademais, afirma o Autor, as leis não parecem querer resolver o problema. Não se vê punições aos administradores, nem aos acionistas que violam o sistema do capital social. Há ainda o problema da facilidade com que qualquer um possa re-arranjar o estatuto para que seja feita distribuição de dividendos aos sócios, desde que não se tenha a insolvência como causa imediata da operação.

Todavia, o capital pode ser usado para prevenir acordos de buy-out em companhias com poucos sócios quando um dos sócios morrer ou sair da companhia. Nesse caso, as consequências econômicas sobre a sociedade, sobre o cônjuge supérstite, sobre o sócio que se retira e sobre os que ficam na companhia são severas. Pode ainda ser usado no caso dos acionistas, possuidores de ações sem direito a voto, que fazem uso das classes especiais de capital votante contra administradores que queiram modificar a estrutura do capital social, em prejuízo da companhia, dos acionistas e mesmo dos credores.

Uma vez colocadas tais reflexões, assim conclui o autor:

"Altogether, it must be recognized that the machinery of legal capital established by our corporation acts suffers from a number of deficiencies. Is there nothing to be said for it? Do creditors receive from the system some degree of practical protection despite its analytic frailty? To make such a persuasive is impossible but perhaps something can be put together"199.

${ }^{199}$ In ob. cit., p. 95. 
Afirma o autor que a grande força do argumento ainda está no aspecto histórico-cultural, porque por 150 anos se têm afirmado que uma empresa deve ter algo chamado capital social, algo este que adquiriu independência, independentemente da sua importância para credores e as situações cotidianas da empresa.

O efeito parece ser sobretudo psicológico. Toda a comunidade empresária acredita que uma empresa com a cifra do capital social alta, é uma empresa sólida. No entanto, é tudo uma construção frágil, obtida a partir de várias operações contábeis facilmente repetíveis. Mas ainda assim, a sistemática do capital social contribui para uma atmosfera de segurança, na qual mesmo os administradores se vêem impedidos de distribuir os bens das sociedades livremente aos sócios.

No entanto, o que parece certo é que os credores criam formas de proteção do seu crédito totalmente alheias à maquinaria do capital social.

\subsubsection{O desenvolvimento do instituto na Europa Continental}

\subsubsection{As características e as críticas ao modelo instituído pela Segunda Diretiva 77/91/CEE do Conselho}

Assim como nos Estados Unidos, as regras sobre capital social surgiram na Europa na segunda metade do século XIX, como resposta à limitação da responsabilidade dos sócios nas companhias de então. No entanto, apesar da origem em comum, notam-se, atualmente, diferenças consideráveis entre as regras que regem o sistema na Europa e nos Estados Unidos.

Friedrich KUBLER ${ }^{200}$ faz uma minuciosa comparação entre os dois sistemas, tendo como base, para as considerações acerca do sistema europeu, a regulamentação implementada pela Segunda Diretiva de 13 de dezembro de 1976. Tendo em vista a ocorrência de mudanças nessa norma em 2006, dividiremos a análise aqui nos períodos anterior e posterior à referida mudança. É de se ressaltar, no entanto, que as modificações realizadas não alteraram a visão regulamentar européia.

Com efeito, segundo KUBLER, a mais moderna teoria considera que a visão européia atual para a regulamentação está fundamentada numa espécie de "dependência de rota": as regras preexistentes e estruturas persistem, uma vez que grandes

\footnotetext{
${ }^{200}$ In The rules of capital under pressure of the securities markets in HOPT, Klaus J. e WYMEERSCH, Eddy (editors). Capital markets and company law. New York: Oxford University Press, 2003.
} 
mudanças poderiam ter consequências indesejáveis ou ter a oposição de grupos de interesses poderosos. Outra teoria afirma que as regras para o capital geralmente são guiadas pelo mercado, ou seja: caso as mudanças mercadológicas tornem as regras existentes ineficientes para o sistema econômico como um todo, as normas terão de ser $\operatorname{alteradas}^{201}$.

Na Europa, a Segunda Diretiva era baseada na distinção entre sociedades anônimas abertas e fechadas, sendo que sua aplicação era restrita às abertas, não abarcando as sociedades limitadas. Não obstante, os Estados membros costumam aplicá-las para ambas as formas. A Inglaterra, por seu turno, costuma reservar para as limitadas uma disciplina bem menos rígida.

Em seu texto anterior a Segunda Diretiva requeria que seus Estadosmembros exigissem um capital mínimo de 25.000 euros para a constituição de sociedades anônimas abertas. E a oferta de ações só poderia ser realizada pelo seu valor nominal ou valor maior. (art. $\left.6^{\circ}\right)$

Embora houvesse a previsão de emissão de ações sem valor nominal, o art. $8^{\circ}$, parágrafo $1^{\circ}$ exigia que tais ações deveriam ser subscritas pelo seu valor contábil. De maneira que não se permitia que as ações fossem subscritas, no total, por valor abaixo do capital social.

No que respeita aos modos de subscrição, a Segunda Diretiva não admitia a subscrição com serviços. E mais, se exige ainda o parecer de um ou mais especialistas, nomeados por autoridade administrativa ou judicial. Esse parecer deve conter a descrição dos bens, os métodos de avaliação usados e assegurar que os bens utilizados equivalem, no mínimo, ao valor do capital social constante do estatuto.

No que tange às regras de manutenção do capital e de distribuição de dividendos aos sócios, a Segunda Diretiva, em seu art. 15 , parágrafo $1^{\circ}$, trazia a proibição de pagamento aos acionistas caso isto pudesse afetar o capital subscrito, permitindo que os Estados-membros impusessem uma reserva adicional que restringiria ainda mais o montante disponível para pagamento de dividendos. KUBLER afirma que na Alemanha, por exemplo, requer que as companhias usem ao menos $5 \%$ das receitas anuais para montar uma "reserva legal" de ao menos $10 \%$ do capital social, a qual será utilizada somente para abrandar possíveis perdas ${ }^{202}$.

\footnotetext{
${ }^{201}$ In ob. cit., pp. 96/97.

${ }^{202}$ In ob. cit., p. 99. Note-se que tal regra está de acordo com o estatuído no no artigo 150 do German Corporation Act.
} 
Ainda como regra relativa à manutenção do capital social, o art. 19, parágrafo $1^{\circ}$ estabelecia que no caso de recompra das ações pela companhia, autorização dada pela Assembléia Geral de acionistas, limitando a transação a ações que não representassem mais de $10 \%$ do capital subscrito, refletindo a visão européia de que este tipo de procedimento só pode ser permitido em situações muito especiais.

Toda a razão de ser das regras acerca do capital social demonstram, segundo KUBLER, que a maior meta é a proteção dos credores. Antes de tudo, capital social é construído para ajudar credores a serem pagos mesmo se a companhia sofrer perdas substanciais. Há, ainda, um segundo propósito de igual importância: a redução do perigo moral resultante da limitação da responsabilidade dos acionistas ${ }^{203}$.

No entanto, não obstante a disciplina do capital social constituir uma espécie de proteção aos credores, existe uma fraqueza básica no sistema de fixação de capital da companhia: a capitalização original pode - e geralmente é - insuficiente, daí que sempre que credores buscam a satisfação nos ativos da companhia isto significa que nada restou, porque o capital foi absorvido pelos prejuízos.

Ocasionalmente, levanta-se a tese de que as regras para o capital social são feitas também para proteger os acionistas, sustentando que a proibição de emitir ações abaixo do valor nominal vem proteger os acionistas antigos que veriam o valor de suas ações se diluírem neste processo. Outrossim, argumenta-se que as limitações aos processos de recompra de ações pela companhia acabam por proteger os minoritários de atos de majoritários, como este, no intuito de limitar a participação daqueles. Outra justificativa para a regulamentação do capital social é a de que companhias recentemente formadas poderiam se tornar insolventes caso um processo de perdas não fosse rapidamente estancado através da absorção dos prejuízos pelo capital social estatuído.

Seja ineficiente ou eficiente, o certo é que toda essa sistemática implica em custos à companhia. Tanto assim que $\mathrm{KUBLER}^{204}$ afirma que as regras sobre o aumento de capital vêm desacelerar o processo de formação de uma companhia e o aumento de seu capital pela emissão de novas ações. Isto se verifica através, por exemplo, do entrave representado pela necessidade de haver, para que se ofereçam bens para subscrição, a análise de especialistas e posterior exame do relatório pela assembléia. Outros exemplos de obstáculo posto por este tipo de regras são a limitação à distribuição de dividendos aos

\footnotetext{
${ }^{203}$ Idem, pp. 100/101.

${ }^{204}$ In ob. cit., p. 102.
} 
acionistas e aos processos de recompras que, restritos, impõem à companhia os custos de um aumento de capital.

A partir dessa análise, KUBLER ${ }^{205}$ conclui que os principais elementos gerados pela sistemática européia sobre capital social são os que seguem:

1. As companhias são vistas como uma instituição que deve ser moldada para resolver possíveis conflitos entre os vários credores que contribuem para o funcionamento das mesmas.

2. As empresas tendem a possuir controle mais concentrado.

3. A competição legislativa dentro de solo europeu é vista como indesejável, por ser a harmonização das normas a este respeito em solo europeu uma meta.

Ao autor não parece correto que a Europa adote o sistema americano, em razão dos custos e da possibilidade de ser ainda menos eficiente. Isso além do fato do possível choque de grupos de interesses, favoráveis e contrários.

Um destes grupos é o dos credores, representados, sobretudo, pelos bancos. Desde que os riscos dos empréstimos de longo prazo aumentaram consideravelmente, estas instituições financeiras passaram a se interessar em negócios envolvendo o mercado de ações, o que torna estes agentes econômicos mais propensos a aceitarem, em vez de uma legislação estatal rígida, um sistema corporativo baseado especialmente numa lógica mercantil.

Outro grupo de interesse relevante é o formado pelos trabalhadores. Estes possuem forte interesse na estabilidade financeira da companhia na qual trabalham justamente para que possam manter seus cargos. Por esta razão, preferem o sistema europeu tradicional de regulamentação por este incentivar crescimentos menores, mas estáveis, em oposição ao sistema americano, no qual o risco para se aumentar o valor das ações é consideravelmente maior.

Por último, KUBLER coloca o legislador como um grupo, defendendo que os escassos recursos para a produção de leis são já absorvidos pela necessidade de satisfazer importantes grupos eleitorais. O autor afirma, categoricamente, que enquanto não houver uma organização forte de interesses no sentido de orientar a regulamentação sob um viés mais mercadológico, mudanças substanciais no ordenamento presente não devem ser esperadas ${ }^{206}$.

\footnotetext{
${ }^{205}$ Idem, p. 104.

${ }^{206}$ In ob. cit., p. 107.
} 
Quanto mais as companhias optam por eleger, como fonte maior de fundos corporativos, o financiamento pelos próprios acionistas, as regras sobre o capital tornam-se cada vez mais um sobrepeso. Isto explica por que a regulamentação americana se afasta do antigo sistema de capital legal.

A Segunda Diretiva, por seu caráter eminentemente restritivo quanto à disciplina do capital social, gera, por não aceitar para a subscrição a prestação de serviços ou fornecimento de suprimentos, óbvios problemas para o funcionamento de companhias de alta tecnologia, nas quais tal prática é comum e importante, pois o aporte de processos criativos neste ramo é essencial para o desenvolvimento do mesmo.

Em geral as regras geradas pelo sistema do capital social servem a reduzir ou mesmo eliminar os riscos para os credores, colocando-os no mesmo patamar, sendo todos obrigados, no caso de insolvência da companhia, a dividir as provisões proporcionadas pelo capital.

Claro, está, no entanto, que os riscos podem ser variados, conquanto sejam estipulados em contratos, e aí cada credor terá maior força, tão logo seja garantido por regras contratuais para além do sistema do capital. Nesse caso as regras do capital social atuarão como limitação à liberdade contratual, precisamente porque reduzirão o poder de barganha dos credores que não poderão exigir muito, já que já estarão relativamente protegidos.

Nesse sistema surgem as agências de riscos que trabalham fornecendo informações para os credores. E a cadeia de informações é em grande parte suportada pelos próprios devedores que, receosos de receberem uma graduação baixa, prestam todas as informações às agências. O que acontece aí é que há uma inversão de valores, porquanto, uma vez que proporcionam um conjunto maior de informações a um custo menor, as agências suplantam as regras do capital no que tange à proteção dos credores, tornando tais regras obsoletas.

Cada vez mais os credores das companhias criam novas formas de garantia do seu crédito, o que demonstra que se perdeu a confiança no sistema do capital social. O que sucede, no entanto, é que os contratos prendem-se sobre bens específicos, os quais ficam indisponíveis a demais credores.

As novas exigências do mercado, as novas formas de financiamento e os novos instrumentos de proteção dos credores têm contribuído para discussão acerca da necessidade da manutenção do sistema do capital social. Sabe-se que nos Estados Unidos as regras já foram abolidas, na Europa ainda persistem. 
Isso se deve, claro, ao crescimento do mercado, mas também ao fato de que os novos instrumentos de proteção dos credores funcionam desde há muito nos Estados Unidos e só há pouco começaram a se desenvolver na Europa, mais especificamente no que tange a securitização dos créditos, na proliferação das agências de riscos.

Outra explicação ainda pode estar no problema da competição legislativa. Porque se de um lado acelerou a eliminação das regras do capital social nos Estados Unidos, na Europa foi impedida em grande parte em razão da Segunda Diretiva.

Talvez tudo isso tenha contribuído para a urgência de uma reformulação da Segunda Diretiva.

\subsubsection{A reforma legislativa de 2006}

O grande mote da Segunda Diretiva era o estabelecimento de as garantias para proteção dos interesses dos sócios e de terceiros no que respeitava à constituição da sociedade, bem como à conservação e às modificações do seu capital social.

No entanto, em Comunicação de 21 de Maio de 2003 ao Conselho e ao Parlamento Europeu intitulada "Modernizar o direito das sociedades e reforçar o governo das sociedades na União Européia - Uma estratégia para o futuro", considerou-se a necessidade de reformular e simplificar o normativo como forma de contribuir para o incremento da eficiência e da competitividade das empresas sem reduzir a proteção dos credores. Tenha-se claro que o objetivo ali não era desde já remodelar o sistema do capital social, ou aboli-lo, mas tão só aprimorá-lo.

Com efeito, atestou-se a possibilidade de reforma do sistema de subscrição de ações posto que se facultou aos Estados-membros a possibilidade de permitir a subscrição também com bens que não o dinheiro, ficando dispensada a avaliação de tal bem por perito, exceto no caso de haver exigência por parte de algum minoritário.

No que tange às reservas deixou-se claro que as sociedades poderiam adquirir suas próprias ações desde que o valor empregado não ultrapassasse o limite das reservas passíveis de distribuição, e desde que autorizada em Assembléia Geral, sendo ainda estipulado que o período durante o qual se poderia permitir tal autorização deveria ser alongado, com o intuito de flexibilizar e dinamizar o processo decisório em vista dos avanços do mercado.

Ademais, objetivou-se que as sociedades pudessem prover ajuda financeira a terceiros para que estes adquirissem suas ações, com fundos provenientes das reservas de 
distribuição, com fulcro a "reforçar a flexibilidade no que diz respeito aos direitos que acompanham a participação no capital das sociedades", sem que isso afete a proteção a credores e acionistas.

Garantiu-se ainda a possibilidade de os credores intentarem ações judiciais ou mesmo medidas administrativas em caso de prejuízo advindo de redução do capital social.

Todas essas expectativas culminaram na edição da Directiva 2006/68/CE do Parlamento Europeu e do Conselho de 6 de Setembro de 2006. 


\section{Capítulo 3. Securitização}

\subsection{A securitização de créditos}

Ao longo dos últimos anos, a securitização tem sido crescentemente utilizada como fonte de captação de recursos para bancos e outras instituições financeiras. Oriunda do termo inglês securities, a palavra securitização indica a transformação de créditos em lastro para a emissão de títulos ou valores mobiliários.

Sabe-se que a o instituto localiza-se entre as fontes externas de origem de recursos para as companhias, classificada como recurso de terceiros ${ }^{207}$. É uma das formas de financiamento independentes da intermediação bancária e pode ocorrer por meio de uma sociedade de propósito específico ou por um fundo de investimento.

NORONHA é assente em considerá-la como um contrato atípico e inominado com fulcro na cessão de lastro para emissão de valores mobiliários. Contrato este que dá origem a outros, para que se possa dar vida à operação objeto ${ }^{208}$.

A securitização de recebíveis implica a cessão de créditos, os recebíveis, que uma instituição detém contra um terceiro a um veículo securitizador. Tal veículo pode estar organizado sob a forma de Sociedade Anônima com o propósito específico (objeto social) de aquisição de recebíveis. Nos dias de hoje apresenta-se como mais usual a utilização do mecanismo do Fundo de Recebíveis em Direitos Creditórios - FIDC, a ser apresentada adiante.

A sociedade de propósito específico que aqui chamaremos Companhia Securitizadora procederá à emissão de títulos e valores mobiliários lastreados nesses recebíveis. Tais valores mobiliários serão repassados a investidores e o valor daí arrecadado será repassado à instituição financeira que cedeu o crédito.

Findada a relação entre a instituição cedente do crédito e a Companhia Securitizadora, esta se torna credora daqueles que deviam àquela. Dessa maneira, os devedores terão de pagar à Securitizadora os valores das prestações referentes aos créditos que obtiveram e esse valor será repassado aos Investidores proporcionalmente

\footnotetext{
${ }^{207}$ Ver, a esse respeito Ilene Patrícia de NORONHA, Securitização de recebiveis comerciais e industriais. Tese apresentada a Faculdade de Direito da Universidade de São Paulo como requisito para obtenção do título de Doutor, 2004, p. 25

${ }^{208}$ Cf. ob.cit., p. 28.
} 
aos títulos por estes adquiridos. A amortização e resgate dos títulos estão condicionados ao pagamento dos créditos correspondentes.

Importante ressaltar o caráter sui generis da empresa securitizadora, cujo único intuito é servir de ligação entre os ativos da originadora e a poupança dos investidores. Não pode tal entidade buscar recursos no sistema bancário, ao contrário, deve buscar recursos nos recebíveis financeiros, bem como pela emissão de títulos como ações e debêntures.

O mecanismo da securitização busca a separação do risco de crédito dos ativos, sendo securitizado o risco de crédito da instituição originadora. Para isso, essa instituição vende os ativos especificamente identificados à Companhia Securitizadora, que emite os títulos para os investidores. É através dessa venda, definitiva, que os ativos são legalmente separados dos da instituição financeira. Assim, se esta requerer falência, nem os credores não garantidos nem os investidores compradores dos títulos não teriam recurso contra os ativos e seus respectivos fluxos de caixa.

Tal estrutura segue melhor explicada no diagrama abaixo:

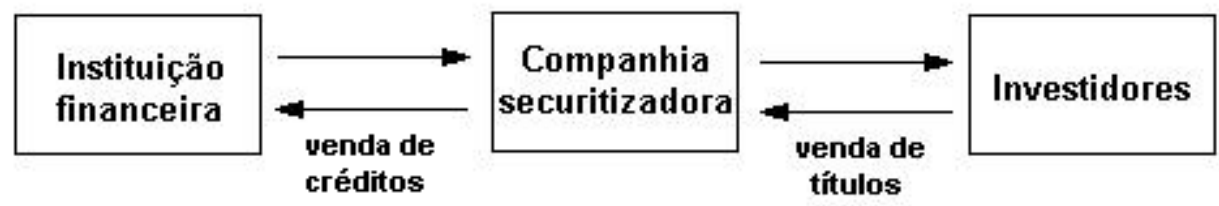

A operação de securitização deve ser observada segundo um ponto de vista mais amplo, em respeito à liberdade contratual, de maneira que não importa na simples conversão dos créditos em valores mobiliários, mas na manutenção de lastro para emissão de títulos como na geração de receitas para a empresa originadora.

Com efeito, a securitização importa em isolamento dos recebíveis, segregando-o dos riscos do originador, de maneira que os credores deste não têm pretensão sobre a cessão em si, tampouco sobre os créditos cedidos. Isto como forma de proteger os investidores.

A cessão dos créditos, nos termos do art. $286^{209}$ do Código Civil poderá ser feita sem solenidades, bastando o acordo de vontades entre cessionário e cedente. Haverá,

\footnotetext{
209 “Art. 286. O credor pode ceder o seu crédito, se a isso não se opuser a natureza da obrigação, a lei, ou a convenção com o devedor; a cláusula proibitiva da cessão não poderá ser oposta ao cessionário de boa-fé, se não constar do instrumento da obrigação."
} 
no entanto, a obrigação de notificação do devedor, de acordo com o art. $290^{210}$ do mesmo diploma. É possível que a cessão ocorra já no momento da venda mercantil, ou mesmo na entrega da mercadoria.

\subsection{A perspectiva do mercado}

A operação de securitização consiste num conjunto de contratos, pelos quais se faz a venda de recebíveis ao veículo securitizador, já existente ou criado apenas para isso, de maneira que tais recebíveis servirão como lastro para emissão de um título ou valor mobiliário. Dessa maneira não há exposição do comprador ao risco do originador dos recebíveis.

Cada fase da securitização, representada por contratos autônomos, porém coligados, é considerada individualmente. E assim é analisada, principalmente na análise do risco da operação. No entanto, embora se tratem de contratos distintos, por força de terem a mesma finalidade econômica e de existirem numa sequência lógica, estes são considerados como unidos num mesmo contrato ${ }^{211}$.

A securitização tem que ver sobretudo com mercados eficientes. $\mathrm{Na}$ perspectiva de que os mercados eficientes são aqueles em que os preços refletem diretamente as informações disponíveis a todos os seus participantes. E os mercados eficientes são a exigência indubitável para o crescimento das economias modernas e essa relação se dá em razão de que em mercados pouco desenvolvidos o financiamento empresarial é realizado em uma relação direta entre o poupador e o tomador, o que inviabiliza a alocação de grandes somas para empreendimentos de grande porte.

Com os avanços econômicos o mercado de valores mobiliários tem se prestado às funções de financiamento. Inegável que, mesmo sendo uma operação que privilegia a desintermediação bancária, a securitização se desenvolveu muito em razão da atividade das instituições financeiras na compra e no fornecimento dos recebíveis e valores mobiliários oriundos da operação de securitização.

$\mathrm{Na}$ atual perspectiva de desenvolvimento da economia, de desintermediação financeira, em que o mercado financeiro tradicional dá lugar ao mercado de capitais, com

\footnotetext{
210 “Art. 290. A cessão do crédito não tem eficácia em relação ao devedor, senão quando a este notificada; mas por notificado se tem o devedor que, em escrito público ou particular, se declarou ciente da cessão feita." ${ }^{211}$ É o que afirma NORONHA: "In casu, a securitização para ocorrer no universo fenomênico necessita de uma pluralidade de serviços, sendo que cada um desses serviços já está tipificado nos respectivos contratos nominados, porém, na visão pragmática, acabam tais serviços por fundir-se em um só contrato, sob o influxo de uma só causa, de uma única função econômica", in ob. cit. p. 95.
} 
integração dos mercados globais, a securitização desponta como um dos novos instrumentos jurídicos financeiros. A operação de securitização pelo fato de que representa inegável acesso ao mercado de capitais, constitui-se em alternativa de investimento e financiamento, para além da intermediação bancária. Ora, daí porque representa alternativa de manutenção da atividade produtiva da empresa.

\subsection{As vantagens da securitização}

A instituição cedente dos créditos a um securitizador tem várias razões para fazê-lo. Em primeiro lugar, a securitização amplia as alternativas de captação de recursos disponíveis para a companhia, fornecendo um fluxo de caixa gerado pelo crédito ao longo da vida deste ativo. Isso é importante na medida em que a grande maioria dos empreendimentos ainda está em desenvolvimento, não sendo capazes de gerar um fluxo de recursos suficiente para a alocação em outros empreendimentos. Nesse sentido, NORONHA salienta que uma vez realizada a cessão, o cedente não manterá qualquer vínculo ou obrigação com o crédito cedido ${ }^{212}$.

Em segundo lugar, os custos diretos de captação são mais baixos se comparados a outros custos de empréstimos comuns, ainda mais em relação a dívidas sem garantias ${ }^{213}$. Além disso, a estrutura da securitização permite a transferência dos ativos e dos respectivos riscos, fazendo com que os ativos possam ser liberados e utilizados para outros fins. Assim, um perfil de menor risco faz não só com que os custos de captação sejam menores, mas também com que seja proporcionado um valioso hedge a longo prazo.

A securitização também possibilita que empresas pequenas ou financeiramente fracas, com pouco histórico de mercado, tenham acesso à captação de recursos financeiros a custos competitivos, diminuindo barreiras de entrada a certos setores econômicos e proporcionando o crescimento dos novos entrantes no mercado bem como a realização mais rápida de economias de escala operacionais.

Ademais disso, sabe-se que há uma competição em todos os setores da economia por um tipo de capital eficiente e barato, donde a necessidade de novas formas de financiamento.

\footnotetext{
${ }^{212}$ In ob. cit., p. 98.

${ }^{213}$ Ver GAGGINI, Fernando Schwarz. Securitização de recebíveis. São Paulo: Liv. e Ed. Universitária de Direito, 2003, pp.17 e ss.
} 
Além destas vantagens deve-se ter em conta ainda que a regulamentação governamental sobre as atividades financeiras, com fulcro na redução de riscos, aumenta os custos de um financiamento tradicional.

\subsection{A regulamentação da securitização por intermédio das companhias securitizadoras}

A Resolução $n^{\circ}$ 2.493/98, do Conselho Monetário Nacional (CMN), cuidada em caráter pioneiro por Cássio Martins PENTEADO JR ${ }^{214}$, trouxe parâmetros para a cessão de créditos das instituições financeiras às Companhias Securitizadoras. Tal normativo traz expresso em seu art. $1^{\circ}$ que os créditos cedidos devem ser exclusivamente aqueles oriundos de operações de empréstimo, de financiamento e de arrendamento mercantil contratadas por bancos múltiplos, bancos comerciais, bancos de investimento, sociedades de crédito, financiamento e investimento, sociedades de crédito imobiliário, sociedades de arrendamento mercantil e companhias hipotecárias a sociedades anônimas que tenham por objeto exclusivo a aquisição de tais créditos.

Dispõe também que a Companhia Securitizadora, se captar recursos em território nacional deverá fazê-lo via emissão de debêntures ${ }^{215}$ e ações, e se decidir fazêlo no exterior poderá usar qualquer valor mobiliário que a legislação alienígena permita.

Deverá constar expressamente do estatuto social da Companhia Securitizadora e dos instrumentos de valores mobiliários por ela emitidos que até o resgate dos títulos não haverá transferência do controle acionário dessa sociedade; redução de seu capital; incorporação, fusão, cisão ou dissolução; tampouco a cessão dos créditos ao controlador ou pessoa a ele ligada em termos diferentes daquele do instrumento contratual.

A Companhia Securitizadora deverá deixar expresso que a cessão dos créditos a ela implica a transferência dos contratos, títulos, instrumentos e garantias necessários à execução dos Recebíveis, sendo que a instituição cedente poderá, ou não, coobrigar-se ao adimplemento desses créditos.

\footnotetext{
${ }^{214}$ In A securitização de recebíveis de créditos gerado em operações dos bancos: a Resolução n. 2493 e sua perspectiva jurídica in Revista de Direito Mercantil, Industrial, Econômico e Financeiro, São Paulo, v. 36, n. 111, p. 120 e ss. jul/set. 1998.

${ }^{215}$ Os autores ressaltam que a emissão de debêntures poderá ocorrer a despeito de registro da companhia junto a CVM e que o mesmo órgão não estabeleceu a obrigatoriedade de emissão pública de ações, mas apenas a de debêntures, segundo redação do art. $1^{\circ}$ da Instrução CVM n ${ }^{\circ}$ 281/98. No entanto, deve ser ressaltado que o art. $2^{\circ}$ desse normativo estabelece que o valor nominal mínimo das debêntures deverá ser de $\mathrm{R} \$ 300.000,00$ (trezentos mil reais).
} 
Esclarecem-nos STUBER, BENTIVEGNA e FILIZZOLA ${ }^{216}$ que é vedada a cessão de créditos a prazo à Companhia Securitizadora com a qual a Instituição Financeira cedente mantenha vínculo, nos termos dos incisos III, IV e V, do artigo 34 da Lei $\mathrm{n}^{\circ} 4.595 / 64$ e do artigo 17 da Lei $n^{\circ} 7.492 / 86^{217}$.

A Resolução citada pró́be ainda a Instituição Financeira cedente de readquirir os créditos cedidos, direta (via recompra) ou indiretamente, exceto nos casos previstos.

Para evitar a insolvência da Companhia Securitizadora, que ocorre quando esta não consegue entregar o produto correspondente ao resgate dos títulos, a normativa estabelece meios para evitar a cobrança antecipada destes. Entre estas está a regra segundo a qual o pagamento dos títulos estará condicionado ao prévio adimplemento dos créditos, embora possam ser constituídas garantias a terceiros não ligados aos recebíveis. Ou ainda, no caso dos recebíveis subjacentes serem oriundos de empréstimo ou arrendamento mercantil, a necessária inclusão no termo de emissão da possibilidade do resgate do título ser efetivado com a dação dos recebíveis, bem como da previsão do pagamento dos créditos gerados pelos recebíveis com bens, isso na hipótese dos devedores terem sido decretados falidos.

Os autores afirmam que é necessário proceder a uma distinção quanto às diversas espécies de Recebíveis, já que o tratamento dispensado às instituições financeiras cedentes, à Companhia Securitizadora, aos investidores e aos devedores também é diverso. Com efeito, os títulos a serem emitidos pela Securitizadora poderão

${ }^{216}$ STUBER, W. D.; BENTIVEGNA, E. J.; FILIZZOLA, H. B. O instituto de securitização de créditos do Brasil in Revista Tributária e de Finanças Públicas. São Paulo, v.8., nº 32, maio/jun. 2000.

${ }^{217}$ Assim dispõem tais dispositivos:

“Art. 34. É vedado às instituições financeiras conceder empréstimos ou adiantamentos:

$\cdots$

III - As pessoas físicas ou jurídicas que participem de seu capital, com mais de $10 \%$ (dez por cento), salvo autorização específica do Banco Central da República do Brasil, em cada caso, quando se tratar de operações lastreadas por efeitos comerciais resultantes de transações de compra e venda ou penhor de mercadorias, em limites que forem fixados pelo Conselho Monetário Nacional, em caráter geral;

IV - As pessoas jurídicas de cujo capital participem, com mais de 10\% (dez por cento)

$\mathrm{V}$ - Às pessoas jurídicas de cujo capital participem com mais de $10 \%$ (dez por cento), quaisquer dos diretores ou administradores da própria instituição financeira, bem como seus cônjuges e respectivos parentes, até o $2^{\circ}$ grau."

"Art. 17. Tomar ou receber, qualquer das pessoas mencionadas no art. 25 desta lei, direta ou indiretamente, empréstimo ou adiantamento, ou deferi-lo a controlador, a administrador, a membro de conselho estatutário, aos respectivos cônjuges, aos ascendentes ou descendentes, a parentes na linha colateral até o $2^{\circ}$ grau, consanguíneos ou afins, ou a sociedade cujo controle seja por ela exercido, direta ou indiretamente, ou por qualquer dessas pessoas:

Pena - Reclusão, de 2 (dois) a 6 (seis) anos, e multa." 
estar lastreados em recebíveis financeiros ou imobiliários em geral ou a recebíveis imobiliários, constituídos sob a forma de regime fiduciário.

Dessa maneira, estabelece-se a regra segundo a qual os investidores estarão impedidos de pedir a declaração de insolvência da Securitizadora quando os títulos forem lastreados naqueles créditos fora do regime fiduciário, e o inadimplemento da Securitizadora se dever ao inadimplemento dos devedores da obrigação original; ou quando a Securitizadora não houver constituído, através de terceiros, garantias adicionais sobre os títulos.

Isto, segundo os mesmos autores, se deve ao fato de que já constará do prospecto de emissão dos títulos a informação de que o pagamento deles estará condicionado à quitação da obrigação que lhes originou. É preciso, então, que a Securitizadora receba primeiro, e recebendo não pague os títulos, para que então possa ser declarada insolvente ${ }^{218}$.

O que importa, entretanto, ao presente trabalho é o recurso que a securitização proporciona de segregar riscos e desonerar o patrimônio e o capital social da companhia que detém os créditos originais.

Em verdade, já não existem dúvidas de que a securitização tem obtido grande sucesso devido, principalmente, à transparência envolvida em todo o processo, seja quanto à própria operação em si, seja em relação aos elementos que integram o patrimônio da Securitizadora que emite os valores mobiliários. Dessa forma, é dada ao investidor a possibilidade de avaliar, de forma adequada, os direitos creditórios negociados, prevendose de forma acurada os fluxos de caixa a serem gerados.

Através da securitização, a companhia originadora dos recebíveis incorre em diversos benefícios, tais como a possibilidade de focar em sua atividade fim e assegurar uma fonte estável de financiamento, com liberação de linhas de crédito bancário, ampliação da base investidora e melhora dos índices financeiros, sem falar na eliminação do intermediário do mercado financeiro e a flexibilidade de títulos de captação.

A segurança nos procedimentos de securitização, portanto, são de extrema importância. Assim, a segregação do risco é de salutar importância para a efetividade do

\footnotetext{
${ }^{218}$ Afirmam ainda estes autores que a Securitizadora deverá proceder ao controle do repasse dos créditos aos adquirentes dos títulos, devendo a CVM receber, até o $15^{\circ}$ dia do mês subsequente, informações referentes à aquisição dos títulos e o pagamento ou inadimplência das obrigações originais. Ademais, o art. $5^{\mathbf{o}}$ da Resolução 2.493/98 estabelece que "Ficam o Banco Central do Brasil e a Comissão de Valores Mobiliários, nas respectivas áreas de competência, autorizados a adotar as medidas e baixar as normas necessárias à execução do disposto nesta Resolução, podendo o Banco Central do Brasil dispor sobre o tratamento a ser dispensado aos créditos de instituições em processo de liquidação extrajudicial".
} 
instrumento. Nesse sentido, podemos classificar os tipos de securitização, no tocante à segregação de risco, da seguinte forma:

a) Securitização sem segregação de risco: Os valores mobiliários são emitidos pela companhia originadora dos recebíveis (sem a utilização de uma Sociedade de Propósito Específico). Os citados valores mobiliários vinculam-se aos recebíveis (esses percebidos no fluxo de caixa do projeto) através de um vínculo jurídico real (caso do penhor) ou obrigacional (caso da custódia).

b) Securitização com segregação de risco: Os valores mobiliários são emitidos por uma "Sociedade de Propósito Específico", criada especificamente para gerir o projeto. Dessa forma, passivos já existentes (como fiscais, trabalhistas, etc.) são afastados, evitando a contaminação da lucratividade do projeto ou sua capacidade de captar os recursos de que necessita.

Em alguns casos, pode o processo de securitização ser contaminado por obrigações de empresas originadoras dos recebíveis. Assim, no tocante à qualidade do crédito em função da segurança jurídica dada pelo contrato, a segregação pode ser qualificada como efetiva, relativa ou tênue, assim definidas por Luiz Pereira Xavier BORGES $^{219}$ :

a) Segregação efetiva: o produto ou serviço já foi entregue ou efetivado através de uma relação jurídica regular, sendo atendidos todos os requisitos de um contrato de compra e venda (excetuando-se o pagamento). O risco existe em função do comprador e não do devedor.

b) Segregação relativa: existe a relação jurídica e a obrigação de pagar, porém o bem ou serviço ainda não foi entregue ou totalmente entregue, havendo risco de responsabilidade do vendedor.

c) Segregação tênue: não existe relação jurídica (ou essa pode ser cancelada sem ônus a qualquer tempo). Os recebíveis são quantificados por valores históricos, projetados para o futuro, e o risco é todo do devedor.

No Brasil, a securitização tem sido feita através de debêntures, visto que são os títulos de longo prazo mais flexíveis. Essas são comumente divididas em:

a) debêntures seniores: colocadas no mercado através de uma "Sociedade de Propósito Específico", usadas para captar recursos dos investidores;

${ }^{219}$ Securitização como parte da segregação de risco empresarial, in Revista de Direito Bancário do Mercado de Capitais e da Arbitragem, $\mathrm{n}^{\circ}$ 10, ano 3, outubro-dezembro de 2000, Ed. Revista dos Tribunais, p. 262. 
b) debêntures subordinadas: emitidas pela "Sociedade de Propósito Específico" e subscritas pela sociedade originadora, que integraliza o seu preço mediante a cessão de direitos creditórios. Essas debêntures, segundo BORGES ${ }^{220}$, geralmente trazem, algumas disposições, tais como:

b.1) eventos de liquidação: antecipação automática de vencimento em casos de falência, ou de concordata da empresa originadora dos recebíveis.

b.2) eventos de avaliação: antecipação facultativa dos vencimentos. Ex: alienação do controle da sociedade originadora dos recebíveis;

b.3) fundo rotativo (sinking fund): previsão contratual para permitir aquisição contínua de recebíveis geados pela sociedade originadora;

b.4) conta garantidora: com a aproximação do vencimento das debêntures seniores, o valor arrecadado pela SPE passa a ser retido até aquele montante. Os recursos que restarem na companhia serão utilizados para o resgate das debêntures subordinadas.

\subsection{A securitização no mercado imobiliário e o patrimônio separado}

O Fundo de Investimento Imobiliário foi um dos veículos utilizados pelo setor imobiliário para escapar do mercado da intermediação financeira como fonte de financiamento. Com efeito, foi a Lei ${ }^{\circ}$ 8.668/93 que disciplinou o que o art. $3^{\circ}$ chamou de união entre mercado de valores mobiliários e o mercado imobiliário, segundo uma perspectiva social.

Há também a possibilidade de os recebíveis serem oriundos de relações imobiliárias, nessa hipótese originando os títulos chamados Certificados de Recebíveis Imobiliários.

De acordo com NORONHA, esse título, disciplinado pela Lei n ${ }^{\circ}$ 9.517/97 (art. $3^{\circ}$ ) nasceu da união entre o mercado de valores mobiliários e o mercado imobiliário, com o fim de promover a securitização nesse meio ${ }^{221}$.

Para tais títulos é possível que se estabeleçam garantias de resgate, desde pelo simples provisionamento de fundos para este propósito até a constituição de privilégios ao investidor sobre o ativo da Securitizadora, sem que isso necessariamente impeça-a de negociar com os bens que componham esse ativo.

\footnotetext{
${ }^{220}$ Idem, ibidem.

${ }^{221}$ Cf. ob. cit., p. 72.
} 
É possível ainda que sobre os créditos originários desses títulos estabeleçase regime fiduciário, com a interposição de uma instituição financeira autorizada como garante dos títulos. Nesse caso será constituído um patrimônio em separado composto por todos os créditos protegidos.

Esse patrimônio não se confunde com o da Securitizadora e destina-se exclusivamente à liquidação dos títulos aos quais estão vinculados. Mais: os créditos que o compõem não podem ser objeto de ação execução, nem de constituição de garantias.

Ainda assim, a Companhia Securitizadora poderá conferir aos beneficiários e demais Investidores do Patrimônio Separado, se este patrimônio se tornar insuficiente, o direito de haverem seus Créditos contra o patrimônio da própria Companhia Securitizadora, que deverá recompor o Patrimônio Separado ${ }^{222}$.

Ao Agente Fiduciário serão conferidos poderes gerais de representação da comunhão dos Investidores, inclusive os de receber e dar quitação, incumbindo-lhe assumir, na hipótese de insolvência da Companhia Securitizadora, a custódia e a administração dos Créditos integrantes do Patrimônio Separado, que não se torna insolvente, nos termos do parágrafo único do art. 15 da Lei $n^{\circ}$ 9.514/97.

Por outro lado, a insuficiência dos bens do Patrimônio Separado não dará causa à declaração de sua insolvência, cabendo, nessa hipótese, ao Agente Fiduciário, convocar assembléia geral dos Investidores, para deliberar sobre as normas de administração ou liquidação do Patrimônio Separado.

A semelhança dos Certificados de Recebíveis Imobiliários, a Lei $\mathrm{n}^{\mathrm{o}}$ 11.076/04 criou o Certificado de Depósito Agropecuário - CDA que, diferentemente do CRI, é um título executivo extrajudicial.

Trata-se de um título de crédito representativo de promessa de entrega de produtos agropecuários, seus derivados, subprodutos e resíduos de valor econômico, depositados em conformidade com a Lei $\mathrm{n}^{0}$ 9.973/00 que dispõe sobre o sistema de armazenagem dos produtos agropecuários.

\footnotetext{
${ }^{222}$ Por essa razão alertam-nos STUBER, BENTIVEGNA e FILIZZOLA: "Importante frisar, entretanto, que, nos termos do parágrafo único do art. 12 da Lei $\mathrm{n}^{\circ}$ 9.514/97, a totalidade do patrimônio da Companhia Securitizadora responderá pelos prejuízos que esta causar, por descumprimento de disposição legal ou regulamentar, por negligência ou administração temerária ou, ainda, por desvio de finalidade do Patrimônio Separado", in ob. cit.
} 


\subsection{O Fundo de Investimento em Direitos Creditórios - FIDC}

Ao invés de se utilizar uma Companhia Securitizadora para proceder à transformação dos créditos, é comum a utilização da estrutura de um Fundo de Recebíveis em Direitos Creditórios - FIDC. A operação é simples: o fundo emite cotas que, sendo adquiridas pelos investidores, geram receitas para que o fundo possa comprar créditos de uma sociedade originadora ou de um cedente.

NORONHA afirma que tais fundos têm grande importância para as sociedades anônimas de capital fechado, porquanto representam veículo de acesso delas ao mercado de capitais.

Em geral os fundos apresentam um rígido sistema regulamentar, em específico a regulação é firme no estabelecimento da estrutura de poder e administração da instituição, bem como na política de investimento e regras de transparência, senão vejamos:

A Resolução CMN no 2.907/01 autoriza a constituição e o funcionamento desses fundos. Essa norma estipula que tais fundos devem funcionar sob regulamentação da CVM, razão pela qual este último órgão editou a Instrução CVM no 356/01 ${ }^{223}$ com intuito de proceder a essa regulamentação.

O inciso I do art. $1^{\circ}$ da Resolução $C M N n^{\circ} 2.907 / 01$ traz a regra segundo a qual os ativos em que os FIDCs devem investir são os

"direitos creditórios e títulos representativos desses direitos,
originários de operações realizadas nos segmentos financeiro,
comercial, industrial, imobiliário, de hipotecas, de arrendamento
mercantil e de prestação de serviços, bem como nas demais
modalidades de investimento admitidas na referida
regulamentação".

$\mathrm{O}$ art. $1^{\circ}$ da Instrução CVM n ${ }^{\circ}$ 356/01 define direitos creditórios como sendo precisamente os direitos originários das operações mencionadas no inciso I do art. $1^{\mathrm{o}}$ da Resolução CMN nº 2.907/01, incluindo no rol os warrants e os contratos e títulos referidos no $\S 8^{\circ}$ do art. 40 da Instrução, quais sejam, os contratos mercantis de compra e venda de

\footnotetext{
${ }^{223}$ Essa Instrução foi alterada pelas Instruções CVM nos 393/03, 435/06, 442/06, 446/06 e 458/07, de maneira que o texto que aqui se menciona é o que hoje se encontra consolidado com as alterações.
} 
produtos, mercadorias e/ou serviços para entrega ou prestação futura e os títulos ou certificados representativos desses contratos.

Um Fundo de Investimento é uma comunhão de recursos constituída sob a forma de condomínio $^{224}$, destinada à aplicação em ativos financeiros ou valores mobiliários, ou ainda em outras espécies de ativos, desde que expressamente admitidos pela regulamentação em vigor. Por essa razão, o inciso III do art. $2^{\circ}$ da Instrução traz a definição de FIDC como sendo "uma comunhão de recursos que destina parcela preponderante do respectivo patrimônio líquido para a aplicação em direitos creditórios".

Encontra-se referência legislativa aos Fundos em Condomínio na Lei $\mathrm{n}^{\circ}$ 4.728/65 para aplicação de capital em Carteira diversificada de títulos ou valores mobiliários os quais dependiam de autorização prévia do BACEN a quem cabia a fiscalização.

Cabe referir-se à Lei $n^{\circ} 10.303 / 01$ que alterou o art. $2^{\circ}$ da Lei ${ }^{\circ} 6.385 / 76$ incluindo as cotas de fundos de investimento como valores mobiliários, levando para a CVM a atribuição de registrar e fiscalizar todos os fundos de investimento. Em 1987 o CMN, por meio da Resolução no 1.280 já havia passado para a esfera da CVM os Fundos Mútuos de Ações MS, entretanto, as propostas de alterações na composição da carteira dos fundos deveriam ser formuladas através de voto conjunto da CVM e do BACEN.

Trata-se de um conjunto de recursos administrados por um administrador profissional, organizado sob a forma de condomínio, sem personalidade jurídica, e que tem como objetivo fazer aplicações em títulos e valores mobiliários, procurando valorizar o patrimônio dos investidores que viabiliza a participação de pequenos investidores no mercado de capitais, com administração profissional.

Este instrumento permite a redução de riscos através da diversificação e a redução de custos, incorporando dividendos e outros rendimentos ao valor da quota do fundo.

Criado com o intuito de dar liquidez ao mercado, o FIDC, não é destinado a investidores comuns, mas apenas a investidores qualificados, nos termos do art. $3^{\circ}$, II da Instrução. Por investidor qualificado deve ser entendido, nos termos do art.2 ${ }^{\circ}$, VII da

224 A natureza jurídica dos fundos de investimento é, portanto, a de um condomínio voluntário de bens móveis. Cf. PONTES, Aloysio Lopes. Instituições financeiras privadas. $2^{\mathrm{a}}$ ed. rev. aum. e atual. Rio de Janeiro: Forense, 1982, pp. 121 e ss. 
Instrução, "aquele definido como tal pela regulamentação editada pela CVM relativamente aos fundos de investimento em títulos e valores mobiliários"225.

Nesse aspecto sabe-se que a regulação, na ótica de proteção aos investidores, faz maiores concessões quanto maior é a capacidade financeira do investidor, pressupondo uma correlação entre capacidade financeira e capacidade de entendimento e de avaliação de riscos.

Isto é feito de diversas maneiras, seja estipulando um valor mínimo de investimento pelo investidor, seja estabelecendo um limite mínimo no valor unitário dos títulos.

Exemplo da primeira maneira acima citada, além da criação da figura do investidor qualificado, está também a distinção que a Instrução CVM no 450/07 trouxe à Instrução CVM no 409/04, a figura do investidor "superqualificado", isto é aquele investidor que faz aporte mínimo de $\mathrm{R} \$ 1.000 .000,00$ (um milhão de reais).

Exemplo da segunda maneira está na regra contida Instrução CVM n 429/06 que instituiu o registro automático nas ofertas públicas de distribuição de notas comerciais com valor unitário de no mínimo $\mathrm{R} \$$ 500.000,00 (quinhentos mil reais), desde que sejam divulgadas informações resumidas sobre a oferta.

A Nota Comercial do Agronegócio - NCA, por seu turno, emitida para distribuição pública emitida por companhias, sociedades limitadas e cooperativas que tenham por atividade a produção, comercialização, beneficiamento ou industrialização de produtos ou insumos agropecuários, ou de máquinas e implementos utilizados na atividade agropecuária prevê a emissão de NCA de valor nominal unitário igual ou superior a R\$ 300.000,00 (trezentos mil reais) garantidas por seguro de crédito, ou de valor nominal unitário igual ou superior a $\mathrm{R} \$ 1.000 .000,00$ (um milhão de reais).

Pois bem, tamanha a preocupação da regulamentação, que há o estabelecimento de uma relação de ativos nos quais o fundo pode investir. Assim que o art.

\footnotetext{
${ }^{225}$ A Instrução CVM n 409 traz a definição do que seja investidor qualificado no seu art. 109: "Art. 109. Para efeito do disposto no artigo anterior, são considerados investidores qualificados: I - instituições financeiras;

II - companhias seguradoras e sociedades de capitalização;

III - entidades abertas e fechadas de previdência complementar;

IV - pessoas físicas ou jurídicas que possuam investimentos financeiros em valor superior a $\mathrm{R} \$ 300.000,00$ (trezentos mil reais) e que, adicionalmente, atestem por escrito sua condição de investidor qualificado mediante termo próprio, de acordo com o Anexo I;

$\mathrm{V}$ - fundos de investimento destinados exclusivamente a investidores qualificados;

VI - administradores de carteira e consultores de valores mobiliários autorizados pela CVM, em relação a seus recursos próprios;

VII - regimes próprios de previdência social instituídos pela União, pelos Estados, pelo Distrito Federal ou por Municípios."
} 
40 da Instrução CVM no 356/01 estabelece que a carteira seja composta por 50\% (cinquenta por cento), no mínimo, de direitos creditórios, estipulando um rol taxativo de ativos a serem adquiridos pelo saldo remanescente, ativos estes em geral de renda fixa ${ }^{226}$. Isso não obstante, o parágrafo $2^{\underline{0}}$ desse art. 40 ainda autorizar a realização de operações compromissadas e de operações em mercados de derivativos.

No que tange à estrutura administrativa tem-se que a administração do FIDC cabe exclusivamente a instituições financeiras, entre as quais bancos múltiplos, comerciais e de investimento, segundo norma disposta no parágrafo $1^{\circ}$ do art. $1^{\circ}$ da Resolução CMN $n^{\circ} 2.907 / 01$ e no art. 32 da Instrução CVM n ${ }^{\circ} 356 / 01$.

O órgão de decisão do fundo consiste na Assembléia Geral dos cotistas, que, entre outras faculdades, pode tomar as contas do fundo e providenciar às demonstrações financeiras (inciso I); deliberar sobre a substituição da instituição administradora (inciso III); deliberar sobre a elevação da taxa de administração (inciso IV); e também deliberar sobre incorporação, fusão, cisão ou liquidação do fundo (inciso V). Além destes poderes, à Assembléia Geral ainda é lícito nomear um ou mais representantes que terão a incumbência de fiscalizar as aplicações do fundo, com intuito de proteger os cotistas.

Com efeito, todo o balizamento da ação do fundo deve estar contido em um regulamento. Nos termos do art. 26, II da Instrução CVM nº 356/01 o regulamento é aprovado e alterado pela Assembléia Geral. Entre as principais disposições constantes do regulamento, ali devem constar a política de investimento, os direitos e obrigações das cotas e os prazos para resgate destas.

A Instrução CVM nº 356/01 esboça ainda a preocupação da garantia de um sistema que permita ampla divulgação das informações aos cotistas. Bem assim que o art. 46 obriga a instituição administradora a divulgar qualquer ato ou fato relevante relativo ao fundo, este assim considerado como qualquer ato ou fato que possa influir na decisão do cotista de permanecer ou não no fundo.

E no que tange à transparência das operações, o art. 48 determina que a instituição administradora do FIDC deva colocar à disposição de qualquer interessado que as solicitar as demonstrações financeiras do Fundo, sendo certo que as Demonstrações Financeiras anuais devem ser auditadas por auditor independente devidamente habilitado e registrado na CVM.

226 Títulos de emissão do Tesouro Nacional, títulos de emissão do Banco Central do Brasil, créditos securitizados pelo Tesouro Nacional, títulos de emissão de estados e municípios, certificados e recibos de depósito bancário e demais títulos, valores mobiliários e ativos financeiros de renda fixa, exceto cotas do Fundo de Desenvolvimento Social. 
É de se ressaltar que, a despeito da total regulamentação, que incrementa a segurança jurídica nos investimentos, os fundos apresentam determinadas vantagens em relação à companhia securitizadora.

Com efeito, afirma NORONHA que o FIDC apresenta vantagens tributárias, já que não incidem impostos sobre sua carteira, bem como tem forma de constituição mais simples que a Securitizadora, já que são desnecessárias a constituição e abertura do capital e o registro de distribuição das cotas é automático ${ }^{227}$.

Curiosidade acerca desses fundos é que a regulamentação em vigor exige que seja realizada uma classificação de riscos do fundo por uma agência classificadora especializada. Sobre tais agências importa dizer que ainda não se estabeleceu aqui no Brasil nenhum tipo de regulação sobre suas atividades, estando as mesmas internacionalmente sob crítica.

Isto não obstante, a IOSCO (International Organization of Securities Commissions), organização internacional que congrega mais de cem comissões de valores mobiliários, criou um código de conduta com o intuito de estabelecer parâmetros gerais para a atividade, tendo em vista a influência que as agências exercem no momento do investimento, com fulcro no incremento da transparência e equidade do mercado ${ }^{228}$.

Desta feita, tendo em vista a impossibilidade de se punir as agências nas hipóteses de fraude, essa só poderá ser efetivada na pessoa do gestor do fundo.

Outro aspecto relevante está em que se acredita que o FIDC, na medida em que coloca em carteira os recebíveis das empresas, permite uma separação completa entre o patrimônio do fundo e o do originador ou cedente dos recebíveis, oferecendo maior segurança no que respeita à segregação dos créditos.

Por fim, e ainda acerca da tutela dos cotistas é de se mencionar que o FIDC segue determinadas regras que aumentam os níveis de segurança da operação, entre as quais, tem-se a classificação das cotas, ou série de cotas, por uma agência de risco ao menos no momento das demonstrações financeiras mensais e anuais e a necessidade de auditoria realizada por auditor independente das demonstrações financeiras dos fundos.

\footnotetext{
${ }^{227}$ In ob. cit., p. 169.

${ }^{228}$ Disponível em http://www.iosco.org/library/pubdocs/pdf/IOSCOPD180.pdf
} 


\subsection{Os problemas gerados pela securitização}

Como é afirmado acima, a securitização exerce importante função no que respeita à alocação dos vários tipos de riscos a que estão expostos os participantes do mercado financeiro.

Assim que o risco existente em um determinado negócio pode ser compartilhado com aquele participante que tem melhores condições de suportá-lo.

Com efeito, desde o ponto de vista da distribuição de riscos, a operação de securitização apresenta uma análise do risco de crédito, que é então dividido com os diversos compradores dos títulos emitidos pelo veículo securitizador ${ }^{229}$.

Cabe mencionar que o direito e a economia definem risco com ênfase em critérios distintos. De maneira que, em termos econômicos, o risco tem que ver com incerteza sobre o retorno esperado numa determinada situação; já em termos jurídicos representa incerteza acerca da ocorrência e do momento de um evento futuro.

Contudo, precisamente nesse ponto é que CAMINHA identifica alguns problemas relacionados aos maus usos da securitização, quais sejam a segregação maléfica de ativos e o disfarce das demonstrações financeiras.

Para o primeiro caso tem-se a possibilidade de que sejam segregados os ativos de menor risco, expondo os credores do originador; ou então a segregação de ativos de maior risco, o que exporia os compradores dos títulos emitidos com lastro nesses ativos.

Pode ocorrer, no entanto, sob pena de se questionar o que foi dito acima acerca da segurança dos credores, que há certa relatividade na transferência de risco do originador para o veículo securitizador.

Isto porque pode ser que os ativos transferidos não representem um risco de crédito muito alto, no sentido de que são transferidos mais ativos econômicos que ativos de risco, restando estes com o originador, o que expõe e deixa sem proteção os credores quirografários $^{230}$.

\footnotetext{
${ }^{229}$ Nesse sentido, assim se posiciona Uinie CAMINHA sobre o assunto: "Na securitização, o credor da emissora dos títulos tem, ainda, a exata dimensão da garantia de pagamento de seu crédito, que é o ativo segregado no veículo de propósito exclusivo. Não há concorrência de outros credores, que não os detentores de títulos oriundos da securitização, que também não estão sujeitos ao risco da sociedade originadora. $\mathrm{Na}$ verdade, em negócios de securitização, a responsabilidade de todos os envolvidos é bem determinada: em geral, o originador não responde pelas dívidas do VPE, e este tem responsabilidade limitada aos bem segregados para operação" in Securitização. $2^{a}$ ed. rev. e atual. São Paulo: Saraiva, 2007, pp. 55/56.

${ }^{230}$ Nesse sentido interessante analisar o comentário exposto no Comentário Especial da Moody’s, p. 8: "Embora uma securitização possa ser encarada como um financiamento garantido para propósitos analíticos, sob a perspectiva dos investidores, há importantes diferenças entre a securitização de dívidas e dívidas garantidas. Um credor que concede um empréstimo estruturado com garantias será envolvido nos
} 
No segundo caso, a securitização se prestaria tanto a retirar ativos ruins do balanço, quanto à possibilidade de conceder financiamento a empresas em má situação financeira e por demais expostas aos riscos de crédito.

Importante aqui a constatação que faz CAMINHA acerca da operação de faturização, tendo em vista tais empresas simularem operações de securitização com escopo de fraudar a lei. Com efeito, é necessário que se tenha presente a distinção entre as atividades, porquanto a operação de faturização tem finalidades específicas e diversas, senão vejamos:

Newton DE LUCCA ${ }^{231}$, tratando do tema, explica que, não obstante existirem vários tipos de securitização, tipos estes muito mais ligados aos usos comerciais que à fenomenologia jurídica, a operação teria duas vertentes principais, ligadas ao tipo Old Line Factor. Seriam estas a conventional factoring e a maturity factoring.

O conventional factoring, dita a forma mais tradicional, compreende a seguinte gama de serviços, prestados pelo faturizador ao faturizado, aquisição à vista de créditos com renúncia ao direito de regresso, a gestão desses créditos, notificação ao devedor, entre outros.

O maturity factoring importa na gestão e cobrança das faturas, mas não na atividade de financiamento do faturizado. DE LUCCA é preciso em afirmar que nesse caso a empresa faturizadora, não obstante deixe de antecipar valores a seus clientes, assume os riscos do inadimplemento por parte de terceiros ${ }^{232}$.

Daí que duas grandes diferenças sobressaem, a primeira no tocante à segregação de riscos da originadora dos recebíveis, só conseguida pela securitização, e a outra no que tange aos fins da cessão de créditos, porquanto somente na securitização ela servirá como lastro para a emissão de valores mobiliários.

\footnotetext{
procedimentos de falência. Um credor garantido está numa posição melhor do que um credor quirografário (não garantido) em termos de recuperação do crédito, mas provavelmente enfrentará o atraso decorrente da falência. Este não é o caso dos detentores de notas lastradas por ativos de uma securitização, onde os ativos são vendidos para a SPE e legalmente isolados da falência do originador. Em adição, os ativos penhorados como colateral num empréstimo garantido podem não ser geradores de geração operacional de caixa do originador ao invés dos ativos em si. Entretanto, numa transação de securitização, os investidores são titulares somente do fluxo-de-caixa gerado pelos ativos securitizados. Eles não têm acesso a qualquer fluxode-caixa disponível aos credores quirografários do originador."

${ }^{231}$ In A faturização no direito brasileiro. São Paulo: Revista dos Tribunais, 1986, pp. 19/24.

${ }^{232}$ Idem, p. 21.
} 


\subsection{Capital social e securitização}

Tendo em conta as funções que a operação de securitização exerce para a companhia originadora dos créditos, é possível que se reconheça certa proximidade entre ela e o instituto do capital social. Com efeito, na medida em que se tenha presente as funções que o capital social desempenha, em específico a função de garantir a continuidade das atividades da companhia, isto é a função de produtividade, é de se mencionar que a securitização ao proporcionar novas alternativas de captação de recursos à companhia, gerando um fluxo de caixa em função dos créditos securitizados, a custos mais baixos se comparados a outros custos de empréstimos comuns, além de diminuir as barreiras de entrada a certos setores econômicos, permite à companhia a obtenção de recursos necessários para a manutenção de sua escala produtiva.

Da mesma maneira, caso se tenha em conta que a operação de securitização conduz à segregação de ativos em um veículo específico, para que então este veículo emita títulos com lastro naqueles ativos, há por consequência uma geração de caixa para a empresa, de maneira que ela possa honrar os seus compromissos.

Desta feita, por gerar caixa para a empresa, permitindo a ela o cumprimento de suas obrigações, a securitização representa também uma garantia para os credores, outra das funções do capital social, à qual fizemos referência acima.

Note-se, no entanto, que, a securitização não se coloca como supedâneo do capital social. Trata-se, em verdade, de uma alternativa de financiamento, que tem como resultado benesses semelhantes àquelas geradas pelo capital social.

Ora, resta claro que o instituto do capital social, se serve de tutela, ainda que mínima, mais teórica do que instrumental, aos credores, no mesmo sentido em que serve, pelo menos inicialmente, como fonte de renda para o exercício da atividade empresarial, ainda é responsável pelo estabelecimento de direitos políticos no cotidiano societário.

Ademais, tendo em conta a segurança jurídica acerca da tutela do capital, porquanto o instituto ser regido por rígidas regras positivadas, seja no momento da sua constituição, seja durante a vida da sociedade, uma operação como a securitização, tendo em vista os problemas acima enumerados, no tocante à possibilidade de fraudes, não se teria o condão de inspirar a mesma segurança que o próprio capital social enseja. Assim que, repise-se, a securitização é, sobretudo, método de financiamento, que, uma vez bem realizado, pode complementar parte das funções realizadas pelo capital social. 


\section{Capítulo 4. Desconsideração da personalidade jurídica}

\subsection{A personalização dos entes coletivos, a limitação da responsabilidade e a teoria da desconsideração da personalidade jurídica}

Determinados investimentos exigem a união de várias pessoas que desejam ter em suas mãos a administração do negócio, sem ter de segregar tal controle a terceiros, mas que ao mesmo tempo desejam proteger o seu patrimônio das vicissitudes do mundo negocial. A personalização dos entes fictícios é um instituto jurídico criado para permitir a consecução de determinados empreendimentos, já que se consubstancia na possibilidade de congregar pessoas, a princípio, com o mesmo intuito econômico, dispostas a investir em um determinado empreendimento.

Acerca do nascimento da personalidade, para os nossos diplomas legais, a melhor definição encontra-se apenas em 1916, com os artigos 18 e 20 do Código Civil ${ }^{233}$, vez que os dispositivos do Código Comercial deixavam a desejar. O Código Civil de 2002, seguindo a mesma linha de seu predecessor, também expôs expressamente a matéria em seus artigos 45 e $985^{234}$.

As sociedades personificadas de responsabilidade limitada (e aqui nos referimos apenas à anônima e à limitada) contribuem então para permitir essa união de esforços para a consecução de atividades produtivas, trazendo para si os riscos do negócio, protegendo o investidor. Isso na medida em que se trata de um ente autônomo com direitos e obrigações próprias, distinto da pessoa de seus membros, em que se investe parte de um patrimônio, assumindo-se um risco limitado a esse valor.

Dessa maneira, tendo sido atribuída personalidade jurídica a um determinado agrupamento de pessoas ou de capitais ao qual se concede a limitação da responsabilidade aos investidores, os particulares podem explorar atividade econômica, estando limitados ao montante aportado à sociedade, ficando protegido o patrimônio pessoal destes. Não por outra razão a importância da pessoa jurídica para a economia capitalista.

\footnotetext{
233 “Art. 18 Começa a existência legal das pessoas jurídicas de direito privado com a inscrição dos seus contratos, atos constitutivos, estatutos ou compromissos no seu registro peculiar, regulado por lei especial, ou com a autorização ou aprovação do Governo, quando precisa."

"Art. 20. As pessoas jurídicas tem existência distinta da dos seus membros"

234 "Art. 45. Começa a existência legal das pessoas jurídicas de direito privado com a inscrição do ato constitutivo no respectivo registro, precedida, quando necessário, de autorização ou aprovação do Poder Executivo, averbando-se no registro todas as alterações por que passar o ato constitutivo.”

"Art. 985. A sociedade adquire personalidade jurídica com a inscrição, no registro próprio e na forma da lei, dos seus atos constitutivos (arts. 45 e 1150)"
} 
Durante muito tempo, principalmente na Roma Antiga, o inadimplemento das obrigações era considerado ato de tal gravidade que poderia levar o devedor ao status de escravo, passando a ser de propriedade de seu credor, que poderia mesmo vendê-lo no mercado estrangeiro, tudo no intuito de satisfazer o crédito.

Como o passar do tempo, e em grande parte devido à contribuição dada pelas corporações e fundações da Idade Média, vai sendo reconhecido o instituto da "pessoa jurídica", uma entidade autônoma, distinta de seus membros ou componentes. Isso, entretanto, não representava já assunção do princípio da limitação da responsabilidade, até porque tais entes eram considerados um conjunto de pessoas naturais, devendo estas, solidariamente, responder, pelas obrigações pactuadas pelo ente.

Numa análise mais profícua da história da limitação da responsabilidade, temos que a limitação da responsabilidade dos sócios nasce na Inglaterra no final do século XVIII, quando as cartas de incorporação foram concedidas pela coroa contendo tal benefício. E daí em diante foi se desenvolvendo em razão das necessidades do comércio.

Nos Estados Unidos o desenvolvimento é um pouco mais tardio, senão que apenas a partir do século XIX é que se percebem formas de associação sem a regra vigente de responsabilidade ilimitada dos sócios. E a questão toma maior forma a partir do julgamento do caso Wood vs. Dummer em 1824.

Aos poucos vão surgindo determinados mecanismos de proteção desse novo ente, blindando os seus membros e dando azo ao cometimento de inúmeras fraudes. Isto é, muda a situação do credor que, se antes podia dispor do seu devedor, agora estava desprotegido lidando com empresas sem patrimônio em razão de atividades fraudulentas dos sócios.

Dissemos páginas atrás, reportando-nos a ASCARELLI, que a limitação da responsabilidade tem natureza excepcional, consagrando-se como um privilégio estabelecido por um ato legislativo. Excepcionalidade essa que se torna regra no século XX com as exigências dos negócios mercantis.

A sociedade anônima não é senão um artifício que permite o desenvolvimento de determinados negócios por pessoas que desejam se beneficiar da limitação da responsabilidade ao montante investido. É, nesta concepção, um patrimônio distinto, separado de um montante anterior, ao qual se atribui personalidade, isto é, imputam-se direitos e deveres.

Mas a regra de limitação de responsabilidade supõe como forma de proteção das contrapartes nas relações obrigacionais desses entes o patrimônio separado 
personalizado e a publicidade de todos (ou quase todos) os atos ali praticados. Assim é que essa carapaça jurídica pode contribuir para uma enormidade de fraudes e abusos. Isto porque, ante a possibilidade de a sociedade contrair obrigações em seu nome, nada impede que estas superem a sua capacidade econômica, não restando aos terceiros senão prejuízos, locupletando-se os sócios, falindo a sociedade.

A fim de coibir esse uso indevido da pessoa jurídica surgiu o instituto da desconsideração da personalidade jurídica. Nascido "disregard of legal entity”, da tradição jurisprudencial da Inglaterra, tal instituto estendeu-se aos Estados Unidos, com o "lifting the corporate veil", de lá alcançando o mundo inteiro, recebendo as mais diversas definições ${ }^{235}$. Embora a decisão precursora da teoria da desconsideração da personalidade jurídica tenha se dado em 1809, no caso Bank of United States v. Deveaux, o caso de maior repercussão mundial deu-se apenas em 1897, na Inglaterra, no caso Salomon v. Salomon \& Co.

$\mathrm{O}$ ato de se ultrapassar a personalidade jurídica de uma sociedade em busca da responsabilização de seu sócio, visa obstar a prática de utilização da empresa como instrumento apto ao cometimento de atos ilícitos. Comentamos anteriormente que foi precisamente a limitação da responsabilidade dos sócios que deu início à teoria segundo a qual o capital social exerceria a função de garantia para os terceiros credores da sociedade. Isso, entretanto, não esgota o problema. Em verdade, tal limitação da responsabilidade dos sócios ao valor proporcional ao montante investido na sociedade, possibilitou o cometimento de fraudes pelos sócios em razão dos desvios que manejam dos fins sociais.

$\mathrm{Na}$ tentativa de coibir as ilicitudes e os abusos referidos, sem que se tenha a dissolução parcial da sociedade ${ }^{236}$, é que se pensa na aplicação da teoria da desconsideração da personalidade jurídica. Ora, as benesses que a pessoa jurídica traz devem estar constritas à consecução do objeto social, sempre em respeito à lei e não para permitir abusos.

\footnotetext{
235 "Sintomaticamente tal solução se desenvolveu nos países de Direito não escrito (common law), Estados Unidos e Inglaterra", de acordo com Luciano AMARO in Desconsideração da pessoa jurídica no Código de Defesa do Consumidor, in Revista de Direito Mercantil, Industrial, Econômico e Financeiro. São Paulo, n. 88, out/dez. 1992.

${ }^{236}$ Usamos essa expressão para nos referirmos à hipótese de exclusão/retirada de sócio insatisfeito sem que isso importe no fim da sociedade. Trata-se aí, conforme bem pontuou Samantha Lopes ÁLVARES da adoção do princípio da preservação da empresa, da alcunha de VIVANTE, e exteriorizado já no século XIX, verbis: "Consequentemente, a doutrina e a jurisprudência pátrias, quase que de maneira unânime, albergaram o entendimento de que a morte, a inabilitação, a incapacidade moral ou civil de algum dos sócios, o abuso, a prevaricação, a violação ou a falta de cumprimento das obrigações sociais ou a fuga de algum deles (hipóteses previstas pelos arts. 335, IV, 336, II e III, do Código Comercial revogado) não deveriam mais conduzir à dissolução total da sociedade", in Ação de Dissolução de Sociedades. São Paulo: Quartier Latin, 2007, p. 58 e ss.
} 
Importante ressaltar que a desconsideração da personalidade jurídica não importa no esquecimento da sociedade, isto é, não importa na sua dissolução. Trata-se tão somente de expediente jurisprudencial, momentâneo, de busca de responsabilização direta dos sócios, quando da ocorrência de determinados fatos ${ }^{237}$. A desconsideração não implica na anulação judicial dos atos praticados, mas tão-somente na adoção de determinadas medidas para conformar tais atos com o ordenamento jurídico, livrando-os de vícios.

O que se intenta é atribuir ao sócio conduta que seria imputada à sociedade se a personalidade dela não fosse desconsiderada ${ }^{238}$. É mera exclusão da regra geral que preconiza a responsabilização direta da sociedade já que aqui teremos determinados atos societários considerados ineficazes, destacando não a figura da sociedade, mas a do sócio.

Importa proteger interesse legítimo da sociedade (e não egoístico do sócio), ainda que em detrimento da autonomia deste ente e da limitação da responsabilidade. Precisamente pelo fato de que no caso que reclama a desconsideração, que entendo dever ser a ultima ratio, a sociedade tornou-se veículo para o cometimento de fraudes e outros atos ilícitos ou ilegítimos.

Há, por certo, o problema da ausência de um modelo teórico unívoco que venha explicitar o momento correto para a aplicação do instituto. Todavia, a razão dessa ausência está no fato de a desconsideração ser um conceito ligado à vida concreta da sociedade, não permitindo cogitações apriorísticas a respeito.

Com efeito, há determinados setores que construíram regras próprias, distintas da desconsideração, embora destinadas a solucionar os mesmos problemas. Assim, por exemplo, o setor tributário ${ }^{239}$. Seja como for, sempre que a solução jurisprudencial entender como necessária a aplicação do instituto em comento, esta deve se fiar ao que diz a letra da lei, sem esquecer-se do apoio nos princípios que a informam.

\footnotetext{
${ }^{237}$ Cf. AMARO, ob. cit., p. 74.

238 "A desconsideração da pessoa jurídica significa tornar ineficaz, para o caso concreto, a personificação societária, atribuindo-se ao sócio ou sociedade condutas que, se não fosse a superação, seriam imputadas à sociedade ou ao sócio respectivamente. Afasta a regra geral não por inexistir determinação legal, mas porque a subsunção do concreto ao abstrato, previsto em lei, resultaria indesejável ou pernicioso aos olhos da sociedade.", segundo KRIGER FILHO, Domingos A. Aspectos da Desconsideração da Personalidade Societária na Lei do Consumidor, São Paulo: Revista de Direito do Consumidor, nº 13, p 21.

$239 \mathrm{O}$ art. 135 do Código Tributário Nacional traz expressa a responsabilidade pessoal de determinados agentes quando da atuação contrária à lei, ou em exacerbação de poderes, verbis:

“Art. 135. São pessoalmente responsáveis pelos créditos correspondentes a obrigações tributárias resultantes de atos praticados com excesso de poderes ou infração de lei, contrato social ou estatutos:

I - as pessoas referidas no artigo anterior;

II - os mandatários, prepostos e empregados;

III - os diretores, gerentes ou representantes de pessoas jurídicas de direito privado."
} 
Da mesma maneira, a desconsideração não cabe quando se tratar de sociedades de fato ou irregulares, porque para esta hipótese a lei já prevê a responsabilidade ilimitada dos sócios ${ }^{240}$ e para aquelas nunca foi atribuída personalidade.

Daí a orientação jurisprudencial no sentido de se restringir a personalidade jurídica, para, em determinados casos, alcançar o patrimônio dos sócios diretamente. Orientação esta que foi positivada em legislação ordinária extravagante, assim, por exemplo, o que consta do artigo 28 da Lei $\mathrm{n}^{\mathrm{o}}$ 8.078/90 (Código de Defesa do Consumidor) $^{241}$, ou, ainda, do artigo 18 da Lei no 8.884 de 11/6/94 (Lei Antitruste) ${ }^{242}$ e mesmo no nosso Código Civil, cujo art. 50 traz a possibilidade de desconsideração da personalidade jurídica nos casos de desvio da finalidade ou confusão patrimonial ${ }^{243}$.

Inicialmente, o Projeto do Código Civil de 2002, ao tratar da desconsideração, estabelecia a expulsão do sócio ou a dissolução da sociedade. Tendo recebido inúmeras críticas, o projeto foi emendado, para que, pelo desvio de finalidade ou pela confusão patrimonial, o juiz pudesse decidir que os efeitos de certas e determinadas relações de obrigações fossem estendidos aos bens particulares dos administradores ou sócios da pessoa jurídica.

Assim, a desconsideração vem positivada como uma forma de repressão ao abuso, por meio do desvio de finalidade ou da confusão patrimonial, na utilização da personalidade jurídica das sociedades, denotando que o direito positivo acolhe a teoria da desconsideração em seus reais contornos.

A nova legislação, como se percebe, deixa claro que a desconsideração não extingue a pessoa jurídica, mas estende os efeitos de determinadas obrigações aos sócios e administradores, suspendendo-se episodicamente a autonomia da pessoa jurídica.

\footnotetext{
${ }^{240}$ O código comercial de 1850 , em seu art. 301, já estabelecia que o comerciante irregular poderia ser objeto de restrições como impossibilidade de requerer a falência ou concordata de outro e responsabilidade ilimitada pelas obrigações sociais.

241 “Art. 28.O juiz poderá desconsiderar a personalidade jurídica da sociedade quando, em detrimento do consumidor, houver abuso do direito, excesso de poder, infração da lei, fato ou ato ilícito ou violação dos estatutos ou contrato social. A desconsideração também será efetivada quando houver falência, estado de insolvência, encerramento ou inatividade da pessoa jurídica provocados por má administração.”

242 "Art. 18. A personalidade jurídica do responsável por infração da ordem econômica poderá ser desconsiderada quando houver da parte deste abuso de direito, excesso de poder, infração da lei, fato ou ato ilícito ou violação dos estatutos ou contrato social. A desconsideração também será efetivada quando houver falência, estado de insolvência, encerramento ou inatividade da pessoa jurídica provocados por má administração."

243 “Art. 50. Em caso de abuso da personalidade jurídica, caracterizado pelo desvio de finalidade, ou pela confusão patrimonial, pode o juiz decidir, a requerimento da parte, ou do Ministério Público quando lhe couber intervir no processo, que os efeitos de certas e determinadas relações de obrigações sejam estendidos aos bens particulares dos administradores ou sócios da pessoa jurídica."
} 
Para que se proceda a uma aplicação mais efetiva da teoria, o Projeto de Lei 2426/03 visa regulamentar o art. 50 com escopo de focar a desconsideração naqueles que efetivamente dirigem a sociedade. Isso para que se evitem abusos ou injustiças, no sentido de se atingir pequenos acionistas, desestimulando o mercado. Assim lemos no art. $4^{\circ}$ do citado Projeto:

“Art. 4": É vedada a extensão dos efeitos de obrigações da pessoa jurídica aos bens particulares de sócio e ou de administrador que não tenha praticado ato abusivo da personalidade, mediante desvio de finalidade ou confusão patrimonial, em detrimento dos credores da pessoa jurídica ou em proveito próprio" 244

$\mathrm{Na}$ verdade esse intento de que a desconsideração atingisse efetivamente o responsável pelo ato que a justificava, já havia sido referido por COMPARATO:

"Um dado, porém, é certo. Essa desconsideração da personalidade jurídica é sempre feita em função do poder de controle societário. É este o elemento fundamental que acaba predominando sobre a consideração da pessoa jurídica, como ente distinto dos seus componentes" 245

Fossemos sintetizar as razões que invocam a necessidade de se desconsiderar a personalidade jurídica de uma empresa poderíamos elencar aqui o caso de desvio de finalidade e utilização dela para o cometimento de fraudes e o de preterimento dos interesses sociais e privilégio dos interesses individuais.

E aqui não importa qual teoria acerca da personalidade jurídica a tradição jurisprudencial adotou, vale dizer, não importa se a pessoa jurídica é considerada ficção legal ou se uma realidade pré-normativa, "homologada" por ato estatal. É possível compreendermos a desconsideração tanto em uma como em outra ocasião.

Com efeito, justificável a aplicação do conceito quando pensamos na teoria da ficção de Savigny, por que não teria sentido o Estado criar um determinado ente, ainda que ficcional, que pudesse ser utilizado para prática de fraudes, sem que pudesse combatê-

\footnotetext{
${ }^{244}$ A esse respeito, assim manifestou-se Márcio Tadeu Guimarães NUNES: "Esta alteração é das mais importantes no citado Projeto, pois a melhor doutrina é unívoca ao sustentar que a desconsideração só deve se dar na direção do núcleo de controle ou quando suceda responsabilidade claramente solidária entre uma minoria alinhada a práticas abusivas do controlador. Logo, a priori, é um manifesto equívoco se falar em desconsideração em detrimento das minorias societárias" in Desconstruindo a desconsideração da personalidade jurídica. São Paulo: Quartier Latin, 2007, p. 140.

${ }^{245}$ In ob. cit., p. 295.
} 
lo. Da mesma forma, porque o Estado homologaria entidade cujo fim precípuo estivesse na violação da lei.

São várias as formas que encontraremos acerca da aplicação do instituto. Assim, quando a ilegalidade, ou ilicitude for patente, podemos pensar na desconsideração direta, para se atingir o beneficiário imediato do ato fraudulento que pessoa jurídica permite praticar ${ }^{246}$. Entretanto, quando a fraude estiver acobertada por atos legais, sem que se possa identificá-la de plano, haverá a necessidade da instauração de ação judicial para que seja aquela descoberta e então se possa, em ação autônoma ou em incidente processual na ação em curso, pedir a desconsideração. Sempre respeitado o princípio do contraditório e a motivação dos atos judiciais.

Há também o caso da desconsideração inversa, que ocorre nos casos em que o sócio age ostensivamente, ocultando a sociedade. Nessa hipótese o agente verte bens à sociedade, no intuito de frustrar eventuais terceiros credores. Existe ainda o caso em que a sociedade que dá azo ao cometimento de fraudes faz parte de um grupo econômico, de maneira que não bastaria a desconsideração da personalidade jurídica daquela para se retornar a um estado de legalidade. É preciso, nesse caso, que se atinja aquele de quem as ordens são emanadas, procedendo-se ao uso do instituto tanto quanto necessário.

Não obstante, a base de uma teoria menor da desconsideração da pessoa jurídica é o fato de a diferenciação patrimonial da sociedade, ou até mesmo em razão de sua iliquidez, se afigure como obstáculo à satisfação dos credores. Basta, aliás, que a pessoa jurídica não tenha como honrar seus débitos para que até mesmo outra pessoa jurídica, não sócia, seja alcançada ${ }^{247}$.

As formas de organização societária se apresentam sob diversas espécies para que o empreendedor possa amoldá-las às suas necessidades. Isso faz com que a aplicação da disregard doctrine não se possa resumir a um aspecto tão superficial, sob pena de abalo da segurança jurídica necessária ao bom convívio social, por exemplo, pelo abalo do próprio objetivo da Lei $\mathrm{n}^{\circ} 10.303 / 01$, que reformou a lei societária, introduzindo modificações no sentido de ampliar a proteção das minorias acionárias, buscando criar condições para uma maior captação de recursos junto à poupança popular.

\footnotetext{
${ }^{246}$ Cf. LAMY FILHO e BULHÕES PEDEREIRA, ob. cit.. p. 255.

${ }^{247}$ Vide decisão da $4^{\text {a }}$ Turma do STJ, por maioria, que entendeu que o defeito de uma filmadora da marca Panasonic adquirida no exterior deveria ser suportado pela sociedade nacional somente pelo fato de deter o direito ao uso da marca, como se afere do seguinte trecho: "Se empresas nacionais se beneficiam de marcas mundialmente conhecidas, incumbe-lhes responder também pelas deficiências dos produtos que anunciam e comercializam, não sendo razoável destinar-se ao consumidor as consequências negativas dos negócios envolvendo objetos defeituosos".
} 
Assim, a insolvência ou falência, pura e simples, não pode se afigurar como requisito para a desconsideração, devendo estar atrelada ao fato da má administração, senão a insegurança seria tão intensa que um fator econômico externo poderia levar à quebra uma sociedade que sempre cumpriu com as suas obrigações, surpreendendo os sócios honestos que, via de consequência, restariam arredios à realização de novos investimentos.

Já uma teoria maior da desconsideração da personalidade jurídica baseia-se em sólidos requisitos identificadores da fraude, tendo como regra a prevalência da diferenciação patrimonial e apenas como exceção, diante de situações específicas, o mecanismo pelo qual se ignora o véu societário.

O que se verifica é a tendência cada vez mais frequente, em nosso regime jurídico, de desfazer o mito da intangibilidade dessa ficção conhecida como pessoa jurídica sempre que for usada para acobertar a fraude à lei ou o abuso das formas jurídicas. Assim, necessária se faz à análise do caso específico com fulcro na existência de má administração, ressaltando que inaptidão para o negócio ou eventual insucesso não a caracterizam, necessitando o intuito deliberado de mal administrar, acabando por recair no abuso de direito, excesso de poder, infração da lei, fato ou ato ilícito ou violação dos estatutos ou contrato social.

\subsection{A tese dos custos da limitação da responsabilidade e a do abuso da personalidade}

Em uma análise mais econômica do fenômeno, de fato baseada na análise que a escola de Law and Economics faz do direito, Walfrido Jorge WARDE JUNIOR, diz que a limitação da responsabilidade existe para reduzir os agency costs, isto é, os custos surgidos dos conflitos de interesse interna corporis, envolvendo administradores e acionistas. Especialmente os custos de monitoramento ${ }^{248}$.

Com efeito, a redução de tais custos deriva dos seguintes fatores: haverá redução do risco da perda patrimonial do investidor, posto que o risco cinge-se ao montante aportado; haverá redução dos custos de monitoramento dos próprios acionistas, tendo em vista que os investidores de maior patrimônio, apresentando maior "liquidez" ao adimplemento das obrigações sociais, precisariam vedar o seu patrimônio restante; reduz a possibilidade de haver uma administração eficiente, já que a livre transferência acionária

\footnotetext{
${ }^{248}$ In: Responsabilidade dos sócios: a crise da limitação e a teoria da desconsideração da personalidade jurídica. Belo Horizonte: Del Rey, 2007, p. 156.
} 
poderia permitir a criação de blocos de acionistas que substituam os administradores lenientes.

De fato, respeitadas discordâncias numa ou outra idéia das acima expostas, é de se concordar que há uma redução de custos engendrada pela limitação de responsabilidade dos acionistas. Mas o que acontece é que esse atributo pode se tornar um problema no instante em que a limitação da responsabilidade venha a contribuir para o cometimento de fraudes e ilicitudes.

Com efeito, SZTAJN ${ }^{249}$, não obstante reconheça ser a limitação da responsabilidade fundamental para a existência da grande empresa, alerta acerca dos riscos gerados para os credores no caso de obrigações que excedam o total de ativos da companhia.

A tese sustentada por WARDE JUNIOR é a de que a desconsideração da personalidade jurídica tem menos a ver com a crise de funcionalidade de personificação dos entes coletivos, do que com a crise da limitação da responsabilidade dos sócios ${ }^{250}$.

A teoria de referido autor está em considerar equivocada a tese sempre defendida de que a desconsideração da personalidade jurídica é uma resposta a um problema da personalidade jurídica dos entes coletivos. Ele cita, nesse ínterim, o pensamento de J. Lamartine Corrêa de OLIVEIRA, cuja tese é justamente esta da crise da personalização como fundamento para desconsideração.

De fato o exercício ao qual procede OLIVEIRA é o de enxergar na personalização o caminho para a limitação da responsabilidade, subordinando este fenômeno àquele ${ }^{251}$. Em verdade, para o autor o conceito de pessoa jurídica pode ser entendido como um centro autônomo de interesses, individualmente identificável, distinto das pessoas que o compõem. Seu comportamento, porquanto resolúvel na vontade de seres humanos, não pode ser valorado per se: traduz-se o instituto num instrumento da vontade das pessoas naturais ${ }^{252}$.

Não obstante o fato de as pessoas jurídicas representarem uma carapaça para a consecução de interesses humanos, isto não impede um juízo axiológico do objeto a que se destinam. Isto é, importa ao legislador, na concessão da personalidade jurídica a um determinado ente, sobretudo um conjunto de fatores objetivos que determinam a estrutura

\footnotetext{
${ }^{249}$ In Sobre a desconsideração da personalidade jurídica in Revista dos Tribunais. São Paulo: ano 88, v.762, abr. 1999, p.91.

${ }^{250}$ Idem, p. 187.

${ }^{251}$ In A dupla crise da pessoa jurídica. São Paulo: Saraiva, 1979, pp. 606/607.

${ }^{252}$ Idem, ibidem.
} 
de um agrupamento de pessoas ao qual se pode se reconhecer personalidade jurídica - vale dizer: existem associações de pessoas que podem ser personalizadas e outras que não. No entanto, quando o objeto a que se destina o empreendimento encabeçado por uma pessoa jurídica é ilícito, imoral, esse juízo axiológico passa a ter caráter ontológico desde o ponto de vista desses atributos objetivos que são exigidos.

A idéia de WARDE JUNIOR é a de que a separação patrimonial não é causa da personalização do ente, mas sim de uma renúncia de propriedade sobre as contribuições para o capital social e aquisição de direito de crédito sobre os resultados da companhia. No entanto, a idéia contrária, no entender dele incorreta, levou à percepção de que a personalização conduziria à limitação da responsabilidade do investidor ao patrimônio investido e isto levou à idéia de que a atribuição de responsabilidade aos sócios de uma companhia só poderia ser viabilizada mediante a desconsideração da personalidade jurídica $^{253}$.

\subsection{Capital social e desconsideração da personalidade jurídica}

Já dissemos, lastreados em ASCARELLI, que a idéia de patrimônio separado, tendo em vista o fato de o patrimônio ser constantemente mutável, gera um grande problema para a publicidade dos atos societários, que se sucedem em velocidade de difícil acompanhamento. É aí que, segundo o autor, surge, mormente nos sistemas de tradição romanística, o conceito de capital social, isto é, o valor fixo expresso pelo produto do número de ações pelo seu valor nominal ${ }^{254}$.

A tutela do capital e a sua rígida disciplina representariam, nessa visão, uma resposta à limitação da responsabilidade dos sócios. Ora, nesse sentido, a desconsideração da personalidade jurídica, se enviesada como dissemos na deficiência da própria limitação da responsabilidade, em franca conexão com o instituto do capital social, conforme também já logramos demonstrar, vem subverter a função daquele no sentido de proteção dos credores.

Isso porque seria possível imaginar que se trata do reconhecimento de que houve ineficiência da limitação da responsabilidade, ineficiência no que tange ao custo desta para os credores, em razão de terem frustradas suas expectativas de recuperarem o crédito perdido.

\footnotetext{
${ }^{253}$ In ob. cit., p. 202.

${ }^{254}$ In ob. cit., p. 467.
} 
Tal fator fica mais claro quando pensamos na hipótese de desconsideração por força da subcapitalização societária. Isto tendo em vista que, sequência lógica, a personalidade jurídica distinta e a limitação da responsabilidade dos investidores foram as alavancas para a popularização da sociedade anônima, na perspectiva da formação de um patrimônio apto a responder pelas obrigações assumidas, patrimônio este constituído pelas contribuições dos sócios para o capital social. A subcapitalização, no entanto, não pode ser considerada como causa direta e inevitável para a desconsideração. Isto é, há de se examinar se ela foi causada pelos sócios, por intermédio de fraude, devido à apropriação do patrimônio da sociedade pelos mesmos.

Ora, tal fato não quer significar a descrença do instituto do capital social, quer sim indicar que há um problema adjacente à companhia; um problema não nos seus institutos, mas sim, na forma como eles são fraudados. Isto é: os institutos são usados para causar um dano a outrem e isto não importa em problema resolúvel ao nível ontológico do ente, mas sim na dinâmica do uso da sua estrutura.

É de se ressaltar, ainda, que o uso indevido dessa estrutura produz problemas mesmo para os seus componentes, isto é: se o acionista controlador der causa à determinada situação desconsiderante, tal terá, sem dúvida, prejudicado o minoritário, mormente no caso que nos é mais sensível, que é o da capitalização indevida da companhia.

Destarte, se é de fato um grande instrumento para o credor, quando vê a possibilidade de satisfação de seu crédito contra a sociedade se esvair em razão de fraude, de abuso da limitação da responsabilidade, não é o único instrumento de tutela de seus interesses $^{255}$. Daí que não perde a força, nesse critério, o instituto do capital social.

\footnotetext{
${ }^{255}$ Ver a esse respeito posição jurisprudencial consolidada em diversos acórdãos, nos Tribunais superiores, em que se reafirma que haverá a desconsideração apenas no caso de abuso com o intuito de causar lesão a terceiros. Assim no Resp 876.974 - SP; Resp. 370.068 - Gp, entre outros (julgados pelo Superior Tribunal de Justiça).
} 


\section{Capítulo 5. O patrimônio de afetação e a segregação do risco}

\subsection{Patrimônio}

Antes de adentrarmos no assunto que concerne a esse capítulo, convém observarmos as regras gerais sobre patrimônio, a despeito daquilo que mencionamos no capítulo 2. Para tanto, buscamos nos clássicos as lições que em seguida se transcreve.

\subsubsection{Conceito}

Tratemos do que se entende por patrimônio. Para Bulhões PEDREIRA "patrimônio é o conjunto dos direitos patrimoniais e obrigações da pessoa, que resulta do processo dos fatos patrimoniais a ela relativos". Ele chama de fatos patrimoniais o nascimento e qualquer outra modificação ou extinção de direitos patrimoniais, ou mesmo modificação do valor financeiro destes direitos ${ }^{256}$.

Oscar BARRETO FILHO explica que essa concepção de patrimônio, formada por direitos, começa com Ihering: entende-se que quando se diz que algum bem compõe um patrimônio, na verdade se procede a uma abreviação, uma elisão, porquanto o que de fato pertence ao patrimônio é o direito conexo àquele bem ${ }^{257}$.

Com efeito, para BARRETO FILHO “chama-se patrimônio ao complexo de relações jurídicas de uma pessoa, que tiverem valor econômico"258. Afirmando ainda a controvérsia acerca da indicação das dívidas como componentes do patrimônio de uma pessoa, idéia esta trazida do campo econômico.

Para MARCONDES MACHADO o conceito de patrimônio abarcaria as seguintes características “a) conjunto de relações jurídicas; b) apreciáveis economicamente; c) coligadas entre si, por pertinentes a uma pessoa"259.

Assim, durante a existência do titular do patrimônio, este está em contínua modificação. E a importância de se conhecer a evolução patrimonial de um determinado ente está na possibilidade que existe de se conhecer o conjunto dos fatos financeiros relativos a este ente, ou seja, a capacidade deste de adimplir suas obrigações.

\footnotetext{
256 In Finanças e demonstrações financeiras da companhia: conceitos e fundamentos. Rio de Janeiro: Forense, 1989, pp. 121/122

${ }^{257}$ In Teoria do estabelecimento comercial: fundo de comércio ou fazenda mercantil. São Paulo: Saraiva, 1988 , p.37.

${ }^{258}$ In. ob cit., p. 48.

${ }^{259}$ In Problemas de direito mercantil. $3^{\mathrm{a}}$ tir. São Paulo: Max Limonad, 1970, p. 85.
} 
Existem espécies de patrimônio classificadas a partir de dois critérios distintos: o número de titulares e a abrangência dos direitos patrimoniais. Será, pois, particular ou comum, conforme tenha, respectivamente, um ou mais titulares, bem como será geral ou especial se abranger, respectivamente, todos os direitos e obrigações do titular ou apenas alguns deles.

O conceito de patrimônio geral, conforme a classificação de PEDREIRA, é semelhante ao de esfera jurídico-econômica da pessoa, no sentido de que esta mantém relações jurídicas que se inserem no campo econômico, isto é, contrai obrigações e adquire direitos de natureza patrimonial, os quais, em sua totalidade, compõem o patrimônio geral $^{260}$.

E tal conceito se distancia do conceito financeiro do patrimônio, pelo qual se entende não o conjunto de direitos e obrigações de uma determinada pessoa, mas somente os elementos que tenham valor financeiro.

\subsubsection{Teorias sobre patrimônio}

Várias foram as teorias desenvolvidas sobre o patrimônio. Elas costumam ser divididas em duas grandes classes: a primeira de índole subjetivista, da lavra de AUBRY e RAU e outra de orientação objetiva, à qual se filiam DUGUIT e outros.

A teoria subjetivista liga-se à personalidade como elemento central da noção de patrimônio, porquanto este importaria num conjunto de bens de uma pessoa, como uma universalidade de direito, com fundamento na manifestação de vontade . Os defendentes dessa teoria chegam a três conclusões: i) somente as pessoas, físicas ou jurídicas podem ter patrimônio; ii) toda pessoa tem um patrimônio, ainda que não possua bem algum; iii) cada pessoa somente poderá ter um patrimônio. ${ }^{261}$

PEDREIRA nota ainda outros pressupostos: o titular do patrimônio é o sujeito ativo de todos os direitos patrimoniais e o sujeito passivo de todas as obrigações; e os direitos patrimoniais servem de garantia ao adimplemento das obrigações. Nesse sentido, o conceito de patrimônio geral tem importância para o estabelecimento de um sistema de garantia de obrigações. Vale dizer: é instrumento de tutela dos credores ${ }^{262}$.

\footnotetext{
${ }^{260}$ In ob. cit., pp. 138.

${ }^{261}$ Cf. BARRETO FILHO, ob. cit., p. 49.

${ }^{262}$ In ob. cit., p. 139.
} 
E a característica que nos importa acerca desse conceito é que o se chama de unidade, isto é, diz-se que todos os bens de um devedor, presentes ou futuros, servem, em caráter uno, de garantia das obrigações contraídas.

ZOPPINI afirma que a teoria de AUBRY e RAU foi criticada porquanto a entenderam insuficiente desde o ponto de vista explicativo e a consideraram mesmo um obstáculo ao desenvolvimento do ordenamento jurídico ${ }^{263}$.

PEDREIRA discorda da doutrina clássica que entendia que a unidade decorria da personalidade do indivíduo. Afirma que é opção legislativa e que pode mesmo vir a ser derrogada em casos de conveniência ou necessidade. Isto é: há de fato uma escolha legislativa que define o patrimônio como uno, ou seja, garantia para todos os débitos do titular, sem distinção com relação aos credores, mas esta regra pode ser revogada em casos especiais, donde a possibilidade de estabelecimento de preferência ao adimplemento de determinados débitos ${ }^{264}$.

MARCONDES MACHADO afirma que quase todos os autores afiliados à teoria subjetivista aceitam, como critério de tutela dos credores, a distinção entre patrimônio bruto (soma do ativo) e patrimônio líquido (ativo menos passivo) ${ }^{265}$.

Diz-se ainda que o patrimônio geral é indivisível porquanto não pode ser, sem autorização legal, dividido em diferentes grupos de direitos e obrigações ${ }^{266}$.

A doutrina objetiva, por outro lado, identifica o conceito de patrimônio com o de destinação. O patrimônio seria um conjunto de bens inter-relacionados porque afetados a um fim econômico determinado.

Essa teoria, desenvolvida na Alemanha, afirma que esse traço de subjetividade só pode ser identificado quando se tratar de pessoa física, não sendo a vontade subjacente ao patrimônio que deva ser considerada, mas sim o fim a que se destina, donde o patrimônio não seria de alguém, mas para algo.

ZOPPINI identifica três razões pelas quais o modelo alemão da destinação não foi plenamente aceito pelo direito italiano (e grande parte dos países de tradição civil law). Primeiramente em virtude do limitado acesso ao direito alemão. Depois, porque a substituição do enfoque de "sujeito de direito" sobre o patrimônio pelo de finalidade não

\footnotetext{
${ }^{263}$ In "Autonomia e separazione del patrimônio, nella prospettiva dei patrimoni separati della società per anzioni" azioni in Rivista di Diritto Civile. Padova, v. 48, no 4, lug./ago. 2002, p. 554.

${ }^{264}$ In ob. cit., pp. 138/140.

${ }^{265}$ In ob. cit., p. 84.

266 BARRETO FILHO afirma que a unidade e a indivisibilidade decorrem da própria personalidade, porquanto não pode esta ser dividida em partes quantificáveis ou em universalidades distintas, in ob. cit., p. 49.
} 
parecia um progresso, uma vez que reduzia o titular de um patrimônio a um mero administrador deste, com o intuito de fazer cumprir a finalidade à qual fora destinado. Por fim, porque durante o século XIX criou-se a idéia de que a doutrina alemã era perniciosa em relação àquela já existente ${ }^{267}$.

Seja como for, a nossa doutrina civil entende o patrimônio como massa de responsabilidade, como elemento de garantia das obrigações do titular. Sobre esse ponto passamos a discutir agora.

\subsubsection{Responsabilidade patrimonial}

O conceito de responsabilidade patrimonial tem que ver com a possibilidade da pessoa de responder pelo pagamento das obrigações por ela contraídas. E essa possibilidade, segundo determinação legislativa, é garantia pelos bens que compõem o patrimônio do devedor. Responsabilidade patrimonial, portanto, é aquela construída sobre base legal, em que os bens do patrimônio do devedor se prendem ao adimplemento dos seus débitos ${ }^{268}$.

O fundamento, segundo o entendimento de PEDREIRA, para estruturação desse sistema legal de garantia de adimplemento dos débitos está em que as relações humanas no campo econômico privilegiam a cooperação dos agentes, cooperação esta que acontece mediante relações obrigacionais originadas de direitos de créditos, direitos aos quais, por esta razão, se chama "de cooperação"269.

No entanto, o direito de crédito, deve-se ressaltar, só tem aplicabilidade quando da manifestação de vontade do sujeito passivo. Daí a importância da constrição estatal na busca da satisfação do crédito, já que o Estado, na pessoa do magistrado, substitui a vontade do particular ${ }^{270}$.

Com efeito, na visão de ZOPPINI, a teoria de que o patrimônio é uma entidade única, determinou a relação biunívoca entre patrimônio e vontade do sujeito, relação essa que é pressuposto para a constituição do direito subjetivo, de maneira que a única forma de se privar um determinado indivíduo de seus bens é a partir da manifestação de vontade deste. Outra implicação da teoria da unidade é a da ligação dos bens de um

\footnotetext{
${ }^{267}$ In ob. cit., p. 558.

${ }^{268}$ Assim dispõe o art. 591 do código de processo civil: "O devedor responde, para o cumprimento de suas obrigações, com todos os seus bens presentes e futuros, salvo as restrições estabelecidas em lei”.

${ }^{269}$ In ob. cit., p. 143.

${ }^{270}$ Idem, p. 144.
} 
titular à garantia e satisfação de seus credores, segundo o princípio da universalidade da responsabilidade patrimonial ${ }^{271}$.

O que daí resulta é que a personalidade não é entendida como centro exclusivo de imputação do patrimônio, porquanto o próprio sistema de conexão entre bens componentes do patrimônio e obrigações do seu titular torna objetiva a relação.

A responsabilidade será ilimitada se o credor tiver como garantia todos os bens componentes do patrimônio do devedor. Será, por outro lado, limitada se a garantia do credor for composta por bens específicos do patrimônio do devedor ${ }^{272}$. Nesse ponto é curioso ressaltar que a garantia dos credores do empreendimento específico enviesado pelo patrimônio de afetação é baseada nos bens específicos que são destinados.

Vale ressaltar ainda que algumas obrigações são garantidas pelo que se chama garantia financeira porquanto dizem respeito à garantia proporcionada pelo valor dos bens componentes do patrimônio. E a capacidade de adimplir as obrigações é percebida no balanço patrimonial $^{273}$.

\subsubsection{Sistema de preferência de créditos}

Em regra, todo o conjunto de bens componentes do patrimônio, pelo princípio da unidade, está ligado ao adimplemento das obrigações do titular, de maneira que cada patrimônio funciona, portanto, como unidade distinta de risco de realização do valor de direitos de crédito.

BARRETO FILHO afirma que essa conclusão de que o patrimônio do devedor funciona como garantia comum dos credores, podia ser inferida quando da leitura do art. 1556 do Código Civil de 1916 (cuja redação se repete no art. 957 do Código em vigor $^{274}$ ). Afirmando em seguida que a partir desse suposto, é possível concluir que o patrimônio deve ser compreendido como universalidade de direito. ${ }^{275}$.

\footnotetext{
${ }^{271}$ In ob. cit., p. 554.

${ }^{272}$ Cf. PEDREIRA, ob. cit, p. 146.

${ }^{273}$ Idem, pp. 147/148.

274 “Art. 957: Não havendo título legal à preferência, terão os credores igual direito sobre os bens do devedor comum."

275. Verbis: “(...) Encarado do ângulo de um determinado sujeito, o complexo de relações jurídicas ativas e passivas, com valor econômico, de que é titular, constitui seu patrimônio. Mas a unificação desse complexo de relações jurídicas ativas e passivas, efetuada por força de lei, traduz-se no conceito de universalidade de direito. Emerge, dessas premissas, a conclusão de que patrimônio tem o caráter de uma universitas juris. In ob.cit., pp. 51/52
} 
Sobre o conceito de universalidade de direito, importante notar o comentário de MARCONDES MACHADO ${ }^{276}$ : segundo ele, esteado na pena clássica de PLANIOL-RIPERT, BONNECASE, entre outros, a universalidade de direito, em contraposição a universalidade de fato, apresenta as seguintes características: "1. o, é um complexo de relações jurídicas ativas e passivas; $2 .^{\circ}$, formado por força de lei; $3 .^{\circ}$ para unificação das mesmas relações”.

Isso não obstante, é possível que alguns créditos tenham preferência em relação a outros, de maneira que o risco que alguns credores correm é diverso do de outros credores, conquanto esteja um mais protegido que os outros.

Nesse sentido, costuma-se falar em créditos preferenciais, no sentido de que têm preferência em relação a determinados bens componentes do patrimônio do devedor, isto é, recebem garantia (certeza de adimplemento) um determinado bem; existindo ainda os créditos subordinados, os quais somente serão pagos depois de solvidas as outras obrigações.

\subsection{A separação patrimonial e as regras do patrimônio de afetação}

Como exceção ao princípio da responsabilidade patrimonial, tem-se o patrimônio especial. Em verdade, consiste tal em um subconjunto do patrimônio geral, pelo que compreende apenas alguns direitos e obrigações relacionados a uma pessoa. Por essa razão, entende PEDREIRA, a constituição do patrimônio especial exige autorização legal 277 .

E o importante é dizer que a função de um patrimônio especial é delimitada individualmente, vale dizer, cada tipo de patrimônio especial tem uma função.

BARRETO FILHO trata como similares o patrimônio especial e o patrimônio separado, como exemplos de hipóteses nas quais uma determinada pessoa convive com mais de uma universalidade de direito, isto é, mais de um patrimônio ${ }^{278}$.

Segundo ele, a razão para a separação patrimonial está em que as regras para aquele conjunto de direitos que constitui o patrimônio especial são distintas das regras que regem os demais direitos, constituintes do patrimônio geral. Acresce-se a esse fator, um conjunto de características peculiares ao patrimônio especial: os direitos são afetos a

\footnotetext{
${ }^{276}$ In. ob. cit., p.81.

${ }^{277}$ In ob. cit., p. 140.

${ }^{278}$ In ob. cit., p. 53.
} 
fins específicos; a administração desse patrimônio especial é muitas vezes diversa daquela do geral; a delimitação dos bens que cabem ao patrimônio separado é dada somente pela lei; a vinculação entre elementos ativos e passivos do titular do patrimônio especial é tal que é possível dizer que as obrigações são do patrimônio especial ${ }^{279}$.

Embora se distinga patrimônio separado, como sendo somente um recurso de separação de um conjunto de direitos de um patrimônio, sujeito a um só titular, de patrimônio autônomo, quando se retiram direitos de vários patrimônios para a criação de um novo, independente, "com sujeito próprio ou, pelo menos, com finalidades próprias", ambas as formas são exemplos de patrimônio de afetação ${ }^{280}$.

Para MARCONDES MACHADO o conceito de patrimônio autônomo está no plano dos sujeitos; o de patrimônio separado, no dos objetos ${ }^{281}$.

ZOPPINI aceita a tese de que o patrimônio autônomo seria distinto do patrimônio separado, não sendo certo se diverso do patrimônio destacado ou mesmo do patrimônio segregado. Para o autor qualquer dessas terminações faz referência a: $i$ ) um patrimônio regulado por uma disciplina jurídica particular; ii) a um desvio do princípio da responsabilidade patrimonial ${ }^{282}$.

A discussão sobre patrimônio separado na Itália foi acentuada quando da edição da Lei $\mathrm{n}^{\circ}$ 366, de 3 de outubro de 2001, na qual se delega ao governo a reforma do direito societário, em que se dispõe acerca da possibilidade de se constituir um patrimônio separado específico para um fim pré-determinado, delimitando condições, limites e modalidade de prestação de contas. Dispõe-se ainda sobre a possibilidade de emissão de títulos de participação nesse patrimônio; sobre a publicidade que se exige e mesmo as regras de responsabilidade em relação a tal patrimônio e também as relacionadas à insolvência.

ZOPPINI também é da opinião de que, acerca da questão da delimitação da responsabilidade, a norma contraria a regra geral da responsabilidade patrimonial. Partindo do disposto no art. $7^{\circ}$ da XII Diretiva de harmonização do direito societário (89/667

\footnotetext{
${ }^{279}$ Idem, pp. 54/55. E, acerca da titubeante aceitação do conceito de patrimônio especial pela doutrina, pondera o autor: "Como se verifica, trata-se, no fundo, de uma questão de palavras; uma vez reconhecido que no patrimônio de uma pessoa, pode haver acervos ou massas de bens, suscetíveis de responsabilidades por certos compromissos, exclusivos ou preferenciais, tanto faz chamá-los ou não de patrimônios separados: as conseqüências que disso dimanam são as mesmas".

${ }^{280}$ Cf. BARRETO FILHO, ob. cit., pp. 57/58.

${ }^{281}$ In ob. cit., p. 96.

${ }^{282}$ In ob. cit., p. 550.
} 
CEE) $)^{283}$, o autor afirma, ainda que, em comparação com a sociedade unipessoal e com a limitada, o patrimônio separado representa uma novidade, porquanto constitui uma parte do patrimônio do empreendedor é destinado exclusivamente a uma atividade empresaria ${ }^{284}$.

Entre as benesses do patrimônio separado está a de promover a separação de um patrimônio e a sua posterior destinação a um fim específico, fugindo dos problemas da constituição de uma pessoa jurídica e mesmo dos custos de administração.

ZOPPINI aponta ainda a diminuição dos custos de transação em função da redução dos custos com a constituição e a administração de uma pessoa jurídica. Em verdade, a separação patrimonial será eficiente quando tudo o que se deseja é levar a cabo um empreendimento para o qual seria necessária a constituição de uma pessoa jurídica ${ }^{285}$.

Em verdade, muito do que se consegue com o patrimônio separado no ordenamento de tradição germânica, se obtém com a figura do trust nos ordenamentos dos países de tradição da common law.

Com efeito, acerca da discussão sobre o trust, Melhim Namem CHALHUB conceitua-o como empreendimento pelo qual uma pessoa é investida no direito de propriedade sobe algum bem ou direito, com a incumbência de exercer essa propriedade em benefício, em confiança a outra pessoa ${ }^{286}$.

Esclarece ainda que o trust pode ser destinado à execução de determinados propósitos ou a beneficiar determinadas pessoas, podendo ser classificado em public ou charitable trusts (trusts públicos), que são guiados por interesses definidos pelo instituidor no intuito de beneficiar a sociedade em geral, ou em private trusts (trusts privados), que são estabelecidos no intuito de beneficiar pessoas identificadas pelo instituidor ${ }^{287}$.

Há, entretanto, problemas que envolvem a disciplina e que não passaram ao largo dos doutrinadores. Para ZOPPINI o grande problema do patrimônio separado reside na sua disciplina, já que presa tanto à tradição civil, quanto à empresarial. Afirma ainda

\footnotetext{
283 “Artigo $7^{\circ}$ - Um Estado-membro pode decidir não permitir a existência de sociedades unipessoais no caso de a sua legislação prever a possibilidade de o empresário individual constituir uma empresa de responsabilidade limitada com um património afecto a uma determinada actividade desde que, no que se refere a essas empresas, se prevejam garantias equivalentes às impostas pela presente directiva bem como pelas outras disposições comunitárias aplicáveis às sociedades referidas no artigo $1^{\circ}$ ”.

Disponível em http://eur-

lex.europa.eu/smartapi/cgi/sga_doc?smartapi!celexplus!prod!DocNumber\&type_doc=Directive\&an_doc=19 $89 \& n u \_d o c=667 \& l g=p t$ consultado em 18.09.08. Apenas como nota de esclarecimento, o artigo $1^{\circ}$ referido faz referências às sociedades de responsabilidade limitada.

${ }^{284}$ In ob. cit.. pp. $545 / 547$.

${ }^{285}$ In ob. cit., p. 567.

${ }^{286}$ Cf.. Trust: perspectivas do direito contemporâneo na transmissão da propriedade para administração de investimentos e garantia. Rio de Janeiro: Renovar, 2001, p. 25.

${ }^{287}$ Idem, p. 33.
} 
que a separação patrimonial pode criar uma classe de credores distintos, embora credores do mesmo sujeito, porquanto a separação do patrimônio, no limite, significa uma distinção de imputação de relações jurídicas e a vinculação do patrimônio a uma específica função de garantia, qual seja, à função de garantir as obrigações assumidas na gestão deste patrimônio $^{288}$.

Também para Pierro FERRO-LUZZI o problema existente na teoria do patrimônio separado seria o de que ele teria sido desenvolvido segundo uma perspectiva civilista do sujeito de direito ${ }^{289}$.

Seja como for, a evolução desse problema, sobre virtudes e problemas da separação patrimonial, será discutida adiante. Resta-nos, por ora, tratarmos da disciplina legislativa sobre o assunto em sede nacional.

\subsubsection{A evolução legislativa nacional}

Em fins de 1999, com a edição da Medida Provisória nº 2008, foi criado o sistema de pagamentos brasileiro que já determinava que as câmaras e os prestadores de serviços de compensação e de liquidação não responderiam pelo adimplemento das obrigações originárias do emissor, de resgatar o principal e os acessórios de seus títulos e valores mobiliários objeto de compensação e de liquidação ( $\operatorname{art.} 4^{\circ}, \S 1^{\circ}$ ).

Posteriormente, tal Medida Provisória foi transformada na 2040-7 e, em seguida, a 2115-16, de 23.02.2001, introduziu a figura da separação patrimonial. Tal figura, patrimônio especial, foi mantida quando da conversão dessa Medida Provisória na Lei 10214, de 27.03.2001, sendo formado por bens e direitos necessários a garantir exclusivamente o cumprimento das obrigações existentes em cada um dos sistemas que as câmaras e os prestadores de serviços de compensação e de liquidação estiverem operando $^{290}$.

\footnotetext{
${ }^{288}$ In ob. cit., pp. 550/ 557

289 La disciplina dei patrimoni separati in Rivista della società. Milano, v. 47, n 1, genn./febb. 2002 p. 121 e ss.

290 “Art. $5^{\circ}$ (...) [A]s câmaras e os prestadores de serviços de compensação e de liquidação responsáveis por um ou mais ambientes sistemicamente importantes deverão, obedecida a regulamentação baixada pelo Banco Central do Brasil, separar patrimônio especial, formado por bens e direitos necessários a garantir exclusivamente o cumprimento das obrigações existentes em cada um dos sistemas que estiverem operando.

$\S 1^{\circ}$ Os bens e direitos integrantes do patrimônio especial de que trata o caput, bem como seus frutos e rendimentos, não se comunicarão com o patrimônio geral ou outros patrimônios especiais da mesma câmara ou prestador de serviços de compensação e de liquidação, e não poderão ser utilizados para
} 
Em 4.9.2001, a Lei no 4591/64 foi alterada por meio da Medida Provisória 2221, que instituiu o Patrimônio de Afetação, objetivando garantir a efetividade das incorporações imobiliárias e tendo, assim, uma finalidade protetiva. Constituiu-se, em verdade, em uma nova figura de direito real de garantia, na medida em que importava num patrimônio autônomo, distinto daquele do incorporador, com a finalidade única de garantir os promitentes compradores, ainda que em hipótese de falência dos incorporadores.

Já no momento da criação do instituto algumas críticas lhe eram dirigidas, porque o legislador deixava a critério do incorporador a criação ou não de tal patrimônio $^{291}$. Em 2004, a Lei $n^{\circ} 10.931$, revoga a Medida Provisória acima referida, e, não obstante mantenha facultativa a criação de tal patrimônio, traz incentivos tributários de modo a estimular a criação desse patrimônio separado, com fins a tornar efetiva essa medida de garantia.

$\mathrm{O}$ instituto do patrimônio de afetação pode ser conceituado como um conjunto de bens, de caráter despersonalizado, destacado do patrimônio do incorporador, ou mesmo de terceiros, normalmente constituído com os recursos obtidos da venda das unidades futuras, com a finalidade de garantir os promitentes compradores contra falência ou inviabilidade do empreendimento, bem como contra prejuízos advindos da culpa do incorporador, não sendo afetado o patrimônio pessoal deste. Note-se que não se incluem aí os valores que excederem aquele necessário à conclusão da obra.

Ressalte-se que o instituto foi criado para que se aumentasse a credibilidade do mercado e se atendesse aos ditames de proteção ao consumidor, exarados no Código de Defesa do Consumidor. Assim, a finalidade do instituto é a de assegurar que a poupança, amealhada pelos promitentes compradores com fito à aquisição de imóveis, não se perca em empreendimentos ruinosos, pela atuação fraudulenta de incorporadores que dão destinação estranha à correta dos recursos obtidos por causa da obra.

Assim, inicia a Lei $\mathrm{n}^{\circ} 10.931 / 04$, em seu artigo $1^{\circ}$, facultando o estímulo à adesão a este "regime especial de tributação aplicável às incorporações imobiliárias, em caráter opcional e irretratável enquanto perdurarem direitos de crédito ou obrigações do incorporador junto aos adquirentes dos imóveis que compõem a incorporação". Acredita-

realizar ou garantir o cumprimento de qualquer obrigação assumida pela câmara ou prestador de serviços de compensação e de liquidação em sistema estranho àquele ao qual se vinculam.

$\S 2^{\circ}$ Os atos de constituição do patrimônio separado, com a respectiva destinação, serão objeto de averbação ou registro, na forma da lei ou do regulamento." (grifei)

${ }^{291}$ Cf. AGHIARIAN, Hércules. Curso de Direito Imobiliário, $6^{\text {a }}$ ed. Rio de Janeiro: Lumen Júris, 2006, pp. 207 e ss. 
se que a redução importará de $15 \%$ a $7 \%$, atualmente, se adotado este sistema, sobre a carga tributária das empresas deste ramo de atividade.

Entretanto, é o artigo acrescido 31-A, pela Lei $n^{\circ} 10.931 / 04$ à Lei $n^{\circ}$ 4.591/64, que inicia a regulamentação desta figura real de garantia, facultando, "a critério do incorporador, a incorporação [que] poderá ser submetida ao regime da afetação; pelo qual o terreno e as acessões objeto de incorporação imobiliária, bem como os demais bens e direitos a ela vinculados, manter-se-ão apartados do patrimônio do incorporador $e$ constituirão patrimônio de afetação, destinado à consecução da incorporação correspondente e à entrega das unidades imobiliárias aos respectivos adquirentes" ${ }^{292}$.

O patrimônio de afetação, por óbvio, não deve se comunicar com o patrimônio do incorporador, ou com outros patrimônios de afetação, tendo como limite às dívidas da incorporação referida.

Em qualquer caso, como ressalva o parágrafo $2^{\circ}$ do citado artigo $31-\mathrm{A}^{293}$ da Lei $\mathrm{n}^{\mathrm{o}} 4.591 / 64$, fica o incorporador responsável pelos prejuízos que causar ao patrimônio de afetação, quando então responderá pessoalmente com seus bens. Ressalve-se que a natureza jurídica de garantia real do patrimônio de afetação fica limitada, em sua finalidade, ao comprometimento exclusivo de operação de crédito, cujo produto seja integralmente destinado à consecução da edificação correspondente e à entrega das unidades imobiliárias aos respectivos adquirentes (idem, $\left.\S 3^{\mathrm{o}}\right)^{294}$.

Cada unidade construída torna-se parte do patrimônio de afetação e constitui-se, se não quitada, num crédito do incorporador, crédito este que poderá vir a constituir um título circulável sem que perca a sua natureza de patrimônio de afetação, quando destinado ao pagamento de despesas inerentes à incorporação $\left(\S 6^{\circ}\right)^{295}$.

A idéia é que quaisquer créditos comercializados mantenham sua natureza e finalidade de patrimônio de afetação a garantir a viabilidade do empreendimento,

\footnotetext{
292 “Art. 31-A. A critério do incorporador, a incorporação poderá ser submetida ao regime da afetação, pelo qual o terreno e as acessões objeto de incorporação imobiliária, bem como os demais bens e direitos a ela vinculados, manter-se-ão apartados do patrimônio do incorporador e constituirão patrimônio de afetação, destinado à consecução da incorporação correspondente e à entrega das unidades imobiliárias aos respectivos adquirentes."

293 "§ $2^{\circ} \mathrm{O}$ incorporador responde pelos prejuízos que causar ao patrimônio de afetação."

294 " $\$ 3^{\circ}$ Os bens e direitos integrantes do patrimônio de afetação somente poderão ser objeto de garantia real em operação de crédito cujo produto seja integralmente destinado à consecução da edificação correspondente e à entrega das unidades imobiliárias aos respectivos adquirentes."

295 " $6^{\circ}$ Os recursos financeiros integrantes do patrimônio de afetação serão utilizados para pagamento ou reembolso das despesas inerentes à incorporação."
} 
conforme os objetivos, acima descritos, da Lei (parágrafo $4^{\circ}$ do artigo $31-\mathrm{A}$ da Lei $\mathrm{n}^{\circ}$ $\left.4.591 / 64^{296}\right)$.

Dispõe o artigo sétimo, da mesma Lei de Incorporações, em seu comentado artigo 31-A, que "o reembolso do preço de aquisição do terreno somente poderá ser feito quando da alienação das unidades autônomas, na proporção das respectivas frações ideais, considerando-se tão-somente os valores efetivamente recebidos pela alienação".

Este dispositivo parecer assegurar a destinação específica e autônoma do patrimônio, embora seja também possível compreendê-lo como referência ao reembolso do empreendedor, pelo investimento que se constituiu em afetação.

Assim, considerando-se que o empreendedor faz um investimento prévio ao patrimônio de afetação, este só poderá ser reavido quando novos integrantes aderirem ao empreendimento. Nesse momento, é exigido destes novos adquirentes o valor da cota do terreno, e os empreendedores são então ressarcidos do investimento inicial que fizeram.

$\mathrm{O}$ artigo 44 da Lei $\mathrm{n}^{\mathrm{o}}$ 4.591/64 define como momento em que cessa a responsabilidade do administrador aquele em que os moradores estão livres para ocuparem as unidades construídas, cessando a sua atividade de empreendedor com a averbação no registro em órgão competente da construção das unidades e da posterior constituição da propriedade delas. É a partir daí que o patrimônio de afetação é desconstituído, tornandose possível o alcance aos valores restantes.

Além disso, a possibilidade de captação de recursos de terceiros induz um sistema complexo de garantias, em razão de interesses concorrentes entre o patrimônio de afetação e aqueles que aportaram recursos para a consecução da obra. Em razão disso, surge o dever de se garantir aos financiadores toda informação relativa à comercialização de unidades, prescindindo essa da sua anuência, da mesma maneira que, em caso de cessão dos direitos creditórios advinda da comercialização de cada uma das unidades das edificações, não haverá transferência para o adquirente de nenhuma das obrigações do cedente, nem tão pouco do construtor e do incorporador (parágrafo 12 do artigo 31- ${ }^{297}$ ).

\footnotetext{
296 " $4^{\circ}$ No caso de cessão, plena ou fiduciária, de direitos creditórios oriundos da comercialização das unidades imobiliárias componentes da incorporação, o produto da cessão também passará a integrar o patrimônio de afetação, observado o disposto no $\S 6^{\circ}$."

297 "§ 12. A contratação de financiamento e constituição de garantias, inclusive mediante transmissão, para o credor, da propriedade fiduciária sobre as unidades imobiliárias integrantes da incorporação, bem como a cessão, plena ou fiduciária, de direitos creditórios decorrentes da comercialização dessas unidades, não implicam a transferência para o credor de nenhuma das obrigações ou responsabilidades do cedente, do incorporador ou do construtor, permanecendo estes como únicos responsáveis pelas obrigações e pelos deveres que lhes são imputáveis"
} 


\subsubsection{Da constituição e administração do patrimônio de afetação}

A constituição do patrimônio de afetação, segundo a redação do art. 31-B ${ }^{298}$ da Lei em comento, dá-se mediante averbação do termo firmado pelo incorporador, ou pelos eventuais titulares de direitos reais de aquisição sobre o terreno no Registro de Imóveis. Poderão, eventualmente, existir direitos reais gravando o bem, desde que exercendo a mesma função de garantia em favor da conclusão do empreendimento.

O artigo 31-C dispõe acerca da Comissão de Representantes, criada para fiscalizar a administração do patrimônio de afetação, zelando pelo bom emprego dos recursos ali colocados. Essa Comissão é constituída por pessoa indicada pelos promitentescompradores e demais financiadores, agindo como mandatário, respondendo pessoalmente pelo prejuízo, informacional ou material, que causar em virtude de culpa ou dolo.

A despeito dos seus afazeres próprios, incumbe também ao incorporador a administração do conjunto de bens constituintes do patrimônio de afetação, sendo que os seus deveres estão dispostos nos incisos do artigo 31-D:

Art. 31-D. Incumbe ao incorporador:

I - promover todos os atos necessários à boa administração e à preservação do patrimônio de afetação, inclusive mediante adoção de medidas judiciais;

II - manter apartados os bens e direitos objeto de cada incorporação;

III - diligenciar a captação dos recursos necessários à incorporação e aplicá-los na forma prevista nesta Lei, cuidando de preservar os recursos necessários à conclusão da obra;

IV - entregar à Comissão de Representantes, no mínimo a cada três meses, demonstrativo do estado da obra e de sua correspondência com o prazo pactuado ou com os recursos financeiros que integrem $o$ patrimônio de afetação recebidos no período, firmados por profissionais habilitados, ressalvadas eventuais modificações sugeridas pelo incorporador e aprovadas pela Comissão de Representantes;

$V$ - manter e movimentar os recursos financeiros do patrimônio de afetação em conta de depósito aberta especificamente para tal fim; VI - entregar à Comissão de Representantes balancetes coincidentes com o trimestre civil, relativos a cada patrimônio de afetação;

VII - assegurar à pessoa nomeada nos termos do art. 31-C o livre acesso à obra, bem como aos livros, contratos, movimentação da conta de depósito exclusiva referida no inciso $V$ deste artigo $e$

298 “Art. 31-B. Considera-se constituído o patrimônio de afetação mediante averbação, a qualquer tempo, no Registro de Imóveis, de termo firmado pelo incorporador e, quando for o caso, também pelos titulares de direitos reais de aquisição sobre o terreno." 
quaisquer outros documentos relativos ao patrimônio de afetação; $e$

VIII - manter escrituração contábil completa, ainda que esteja desobrigado pela legislação tributária.

A eventual decretação de falência do incorporador, nos termos da redação do art. 31- $\mathrm{F}^{299}$, não incidirá sobre o patrimônio de afetação, nem tampouco sobre o terreno, edificação e eventuais direitos que lhes acompanhem. É por essa razão que o mesmo dispositivo traz a obrigação de que se reúna, em Assembléia Geral, a Comissão de Representantes, ou um sexto dos titulares das frações ideais, ou, ainda, todos os condôminos, com a finalidade de deliberarem acerca da continuação da obra, ou da dissolução do patrimônio.

Dessa maneira, a Comissão de Representantes passa a ter legitimidade para, em nome dos condôminos, concluir o contrato definitivo com os adquirentes, ainda que após o fim da obra. Tem, ainda, os poderes legítimos para, entre outros, transmitir domínio, e imitir os adquirentes na posse das unidades respectivas $\left(\S 5^{\circ}\right)^{300}$.

É certo que os poderes concedidos à Comissão são delimitados e têm o propósito específico de resguardar os interesses dos condôminos, respondendo pessoalmente os membros em caso de desvio de finalidade.

A Comissão deverá cumprir fielmente o mandato que lhe foi outorgado, prestando contas aos adquirentes e entregando-lhes, segundo disposição do $\S 9^{0301}$, o produto das alienações depois de contados 5 (cinco) dias da efetivação do pagamento. Dispõe, por fim, o art. 31-F que os contratos definitivos somente serão celebrados com os adquirentes que tenham obrigações com o incorporador ou com a entidade financiadora se for comprovado que são adimplentes, devendo ainda prestar algum tipo de garantia.

No momento em que os adquirentes decidem dar seguimento à obra, assumem todas as obrigações e encargos surgidos da incorporação $(\S 11)^{302}$ e passam a responder individualmente, na proporção de sua cota, de sua fração ideal no condomínio. Nesse ponto, cabe ressaltar que é facultado à Assembléia Geral, mediante a aprovação de

299 “Art. 31-F. Os efeitos da decretação da falência ou da insolvência civil do incorporador não atingem os patrimônios de afetação constituídos, não integrando a massa concursal o terreno, as acessões e demais bens, direitos creditórios, obrigações e encargos objeto da incorporação."

300 " $\$ 5^{\circ} \mathrm{O}$ mandato outorgado à Comissão de Representantes confere poderes para transmitir domínio, direito, posse e ação, manifestar a responsabilidade do alienante pela evicção e imitir os adquirentes na posse das unidades respectivas."

301 "§ $9^{\circ}$ A Comissão de Representantes cumprirá o mandato nos termos e nos limites estabelecidos pela deliberação da assembléia geral e prestará contas aos adquirentes, entregando-lhes o produto líquido da alienação, no prazo de cinco dias da data em que tiver recebido o preço ou cada parcela do preço."

302 "§ 11. Caso decidam pela continuação da obra, os adquirentes ficarão automaticamente sub-rogados nos direitos, nas obrigações e nos encargos relativos à incorporação, inclusive aqueles relativos ao contrato de financiamento da obra, se houver." 
dois terços dos adquirentes, a adoção de um critério diferente de rateio. As receitas que restarem após a conclusão da obra, deverão ser destinadas à massa falida, diretamente ou via disponibilização ao Juízo de Falências $(\S 13)^{303}$.

Sem prejuízo das obrigações do incorporador diante de seu papel de empreendedor na edificação, quanto à matéria de afetação incumbe-lhe, na forma do artigo 31-D da Lei $\mathrm{n}^{\circ}$ 4.591/64, diversas outras obrigações, como visto supra.

\subsubsection{Da extinção do patrimônio de afetação}

É possível como forma de extinção do patrimônio de afetação, além da alienação de terrenos e acessões, a denúncia da incorporação, devendo ser restituídas as quantias pagas pelos adquirentes, em conformidade com o art. $36^{304}$, bem como a deliberação da Assembléia Geral no sentido da liquidação do patrimônio em razão de falência do incorporador.

Em qualquer hipótese de cancelamento é exigida averbação no registro na entidade notarial para aperfeiçoamento do feito.

\subsection{Patrimônio de afetação e capital social}

Prendendo-nos à tutela dos credores e à responsabilidade patrimonial, vale dizer, à ligação entre os direitos componentes do patrimônio e os débitos do seu titular, em verdade parecem se equivaler as soluções de se constituir uma pessoa jurídica ou se proceder à separação patrimonial ${ }^{305}$.

E como não há limites à manifestação de vontade, nem tampouco à liberdade contratual, nada impede que uma sociedade que constitua patrimônio separado dê em garantia aos credores deste o restante do patrimônio. E aí, de outra forma, a garantia repousará também sobre o patrimônio geral.

O grande problema estaria, como afirmado acima, na possibilidade que a separação patrimonial cria do estabelecimento de classe de credores pela garantia que

\footnotetext{
303 " $\$ 13$. Havendo saldo positivo entre as receitas da incorporação e o custo da conclusão da incorporação, o valor correspondente a esse saldo deverá ser entregue à massa falida pela Comissão de Representantes."

304 "Art. 36. No caso de denúncia de incorporação, nos têrmos do art. 34, se o incorporador, até 30 dias a contar da denúncia, não restituir aos adquirentes as importâncias pagas, êstes poderão cobrá-la por via executiva, reajustado o seu valor a contar da data do recebimento, em função do índice geral de preços mensalmente publicado pelo Conselho Nacional de Economia, que reflita as variações no poder aquisitivo da moeda nacional, e acrescido de juros de $6 \%$ ao ano, sôbre o total corrigido."

305 ZOPPINI afirma que o já citado art. $7^{\circ}$ da XII Diretiva de Harmonização do Direito Societário (89/667 CEE) deixou claro que é possível conseguir a limitação da responsabilidade patrimonial seja com a separação de um patrimônio submetido a um regime jurídico distinto, seja com a criação de um novo sujeito de direito. In ob. cit., p. 570.
} 
lhes é atribuída, isto é, haverá credores cujo crédito, em verdade cujo adimplemento do crédito, estará reforçado pela circunscrição de bens específicos e determinados, e outros que apenas contarão com a massa formada pelos bens do patrimônio geral.

Assim, àqueles credores aos quais $\mathrm{MANNING}^{306}$ se refere com frequência, os credores não voluntários (aqueles cujo crédito não dispõe de preferência, conforme mencionamos acima), será sem dúvida prejudicial a constituição de um patrimônio separado, que, no limite, segregará bens que antes compunham a massa do patrimônio geral, prejudicando a "garantia geral".

Não há dúvidas, por outro lado, que, desde o ponto de vista dos custos para o instituidor (da pessoa jurídica e do patrimônio de afetação), a separação patrimonial e a posterior subsunção dessa massa a um regime jurídico distinto dos demais será sem dúvida menos onerosa. Isso quando pensamos nos custos de constituição e administração ${ }^{307}$.

Em suas conclusões, DANA-DÈMARET ${ }^{308}$ afirma que o capital social é inerente à noção de pessoa jurídica e se constitui na base do patrimônio social. Afirma que ele representa um elemento central para o financiamento da atividade empresarial, tanto assim que o legislador (comunitário) se preocupou em suavizar as modalidades de reforço do capital e em criar novas técnicas de financiamento, para apoiá-lo.

Ora, e levando em conta que, conforme afirmamos acima, o capital social, na medida em que essencial para a noção de patrimônio líquido, e importante como recurso de tutela dos credores, porquanto havido como o último recurso existente para companhia, este não perde essa sua função quando comparado com a tutela oferecida pelo patrimônio de afetação.

Em verdade, tendo presente a idéia de que é importante para o credor saber a qual bem do devedor se prende o adimplemento do seu crédito, virtude que se deve reconhecer no patrimônio separado, mas também tendo presente a idéia de que toda a garantia adicional pode ser complementada por aquela encontrada no ativo patrimonial geral do devedor (para cuja manutenção servem as regras do capital social), é possível dizer que o patrimônio de afetação não nega a importância do capital social, mas, pelo contrário, a complementa.

\footnotetext{
${ }^{306}$ V. seção 2.10.1 acima.

${ }^{307}$ Cf. ZOPPINI, in. ob. cit., p. 571.

${ }^{308}$ In ob. cit., p. 358.
} 


\section{Conclusões}

Compreende-se que a atividade do empresário consagra o exercício de algumas funções básicas: aquela primordial que importa na constituição da sociedade e a consequente organização dos fatores de produção; bem como a de administração da atividade-objeto da sociedade e a de assunção dos riscos empresariais.

A criação da pessoa jurídica corresponde ao desejo dos indivíduos de colocarem empreendimentos em prática cuja exigência de grandes somas de capital para sua efetivação, bem como os riscos inerentes à atividade a ser desenvolvida, demandam algum tipo de proteção do patrimônio pessoal dos investidores. Fez-se necessário, então, o surgimento de um ente personalizado, titular de direitos e obrigações, capaz de suportar os riscos que produz.

Nesse sentido, os sócios perdem a propriedade dos bens de produção, que passar a ser de titularidade da sociedade, recebendo, em troca, a titularidade de determinados direitos exigíveis contra a empresa. Dentre tais direitos destacam-se os de informação, de deliberação (voto) e de participação nos dividendos.

Por essa razão, tem-se por necessária a composição do capital social: um instituto que, como vimos no decorrer do trabalho, tem múltipla expressão, importando na cifra formal e abstrata constante do passivo, no conceito contábil, representando a soma das contribuições dos sócios, bem como o conjunto de bens destinados a cobrir tal cifra, na denominada acepção real.

É precisamente o instituto do capital social que vai permitir o exercício das atividades empresariais, porquanto permite que a sociedade suporte os riscos da sua atividade fim, ao mesmo tempo em que garante a limitação da responsabilidade dos sócios.

A importância do instituto, então, está em ser meio para a limitação da responsabilidade, porquanto importa na constituição de uma reserva de bens que passará a suportar os riscos da atividade, segregando-o do patrimônio pessoal dos sócios.

O capital social é importante, ainda, para a compreensão de outras figuras societárias, entre as quais o balanço e o lucro. O referido instituto exerce diversas funções dentro da companhia e dentre as funções mais importantes encontramos a de garantia, a política e a de produtividade. 
Ao contrário do que usualmente é afirmado, o capital social não surgiu como uma garantia aos credores, mas sim como uma garantia de continuidade da empresa, exercendo assim uma função de produtividade.

Isto é, na medida em que o capital social, na sua acepção de capital real, ou seja, o conjunto de bens aptos a cobrir a cifra constante do passivo, objetivava congregar os meios aptos ao desenvolvimento do objeto social, acabava por desempenhar essa função de continuidade da empresa.

Foram as exigências da classe mercantil que mudaram a ótica sobre o instituto, passando este a ser considerado também como reserva de garantia das obrigações sociais.

Conforme acima afirmado, a função de garantia, ainda considerada por muitos como a função mais importante exercida pelo capital social, tem por objetivo efetivar a aplicação de alguns princípios, quais sejam, o da exata formatação, o da intangibilidade e o da exata formação para assegurar a solvabilidade dos créditos sociais.

Dessa maneira, a partir da segunda metade do século XIX, a função garantia do capital assume ares de verdadeiro dogma na literatura jurídica. Tanto assim que muito se discutiu, em período anterior à edição do atual diploma societário pátrio, acerca da importância do instituto. Isto em razão das fortes críticas que eram apontadas, devido a uma suposta ineficiência na proteção dos credores, mormente na doutrina estadunidense e européia.

Essa tendência de se considerar o capital social inapto à tutela dos credores permanece também na doutrina contemporânea. Em verdade, observamos que não são poucas as críticas dirigidas ao instituto, muito em virtude da confrontação das regras com as relações fenomênicas entre as companhias e os seus credores, revelando o distanciamento entre tais instâncias.

No entanto, o que se verificou é que, ainda hoje, não se pode postular o fim do instituto, nem sua inutilidade. A crítica exposta não se dirige ao instituto do capital per se, mas apenas à tese que sempre se afirmou de que este prestava efetiva garantia aos credores sociais.

Nosso estudo se relaciona com o surgimento de instrumentos que existem para garantir a solvabilidade dos créditos sociais, ainda que as obrigações da sociedade estejam prejudicadas em razão de atos dolosamente praticados pelos sócios.

Seja como for, a garantia da qual se trata é constituída pelo capital social real, já que a concepção nominalista do capital social não permite compreendê-lo como um 
conjunto de bens aptos a garantir obrigação alguma, porquanto entendê-lo como mera cifra.

Daí que para as sociedades de capitais, da qual a companhia aberta, objeto deste trabalho, faz parte, importa a manutenção da existência e realidade desse capital social real. E é precisamente isso que se pretende quando se cria um sistema que venha a garantir a solvabilidade dos créditos sociais.

A eficácia à garantia de terceiros e mesmo a manutenção da escala produtiva da empresa torna necessária a adequação entre os capitais próprios à companhia e os alheios. Isso para que o capital social nunca tenha valor muito abaixo do passivo, nem muito acima dele, o que poderia mesmo causar uma baixa remuneração aos sócios.

Contudo, o que se percebe é que o regime jurídico do capital social não se presta a garantir a adequação do capital social ao objeto social, de maneira que não pode ser instituto idôneo a servir de garantia aos terceiros credores.

Assim, maior importância deve ser dada à função política. Isto é, à função que $\mathrm{o}$ instituto exerce de assegurar determinadas prerrogativas aos detentores de determinada participação no capital.

Essa função tem relevância quando se verifica a pulverização do capital social entre os investidores. Isto é, o fato dele estar fracionado em pequenas parcelas representadas pelas ações, possibilita a sua dispersão por um grande número de pessoas levando à sua socialização, permitindo mesmo a discussão entre a propriedade de títulos e poder de controle social.

A lei societária determina uma série de prerrogativas aos sócios, já mencionadas no trabalho, de maneira que, de acordo com determinadas porcentagens do capital, é possível a um ou mais sócios praticarem determinados atos.

Como já afirmado, esse estudo teve por objetivo analisar os instrumentos que surgem para dar azo à tutela dos credores sociais, seja por desonerar o capital social das dívidas, seja por garantir uma adequada capitalização social, ou ainda por punir os sócios que venham a utilizar a sociedade como meio de fraude; assim como para garantir a manutenção da fonte produtiva.

Tais instrumentos possibilitam o exercício da mesma garantia aos credores, sem, no entanto, implicar nos problemas que afetam o capital, entre os quais, o da possibilidade da fraude da cifra. 
Assim que a Securitização de Créditos se presta a auxiliar o empresário a conseguir a capitalização adequada da empresa, quando o capital social, originalmente concebido como forma de assegurar que a sociedade esteja efetivamente capitalizada para o exercício da atividade produtiva, não mais consegue fazê-lo.

Nesse sentido, deve ser afirmado que, em conexão com a função de produtividade desempenhada pelo capital social, a securitização ao proporcionar novas alternativas de captação de recursos à companhia, tendo em vista a geração de fluxo de caixa em função dos créditos securitizados, permite à companhia a manutenção de sua escala produtiva.

Ademais, tendo em vista que a operação de securitização permite a segregação de ativos em um veículo específico, de maneira que este veículo utilizará tais créditos como lastro para emissão de títulos, garante-se um fluxo de caixa para que a companhia possa honrar os seus compromissos, representando também uma garantia para os credores, outra das funções do capital social, à qual fizemos referência acima.

Posto isto, não se pode afirmar que o instituto funcione como substituto do capital social, mas como alternativa de financiamento, cujas funções complementam aquelas do capital social.

Se o capital social, como afirmado acima, foi concebido como resposta à limitação da responsabilidade dos sócios, possibilitando até o uso indevido da companhia para a prática de atos ilícitos, tratou-se da desconsideração da personalidade jurídica como recurso dos credores nas hipóteses especificadas em lei, nos casos de cometimento de fraudes.

Conforme tivemos a oportunidade de discutir, a disciplina jurídica do capital social surge intrincada à limitação da responsabilidade dos sócios. Desta feita, se a desconsideração da personalidade jurídica se constrói em razão de deficiência da limitação da responsabilidade, é possível afirmar que houve, de fato, uma subversão das regras do capital social, no que respeita à proteção dos credores, já que estes viram reduzidas as possibilidades de recuperarem seu crédito.

Tal fato fica ainda mais claro quando a hipótese de desconsideração se dá em função de subcapitalização societária. Mas isto em hipótese alguma pode querer implicar no rejeito ao instituto do capital social, porquanto o que há é um problema adjacente à disciplina jurídica da companhia; um problema não nos seus institutos, mas sim, na forma como eles são fraudados. 
Não obstante, é necessário esclarecer ainda que o uso indevido da estrutura possa produzir problemas também para o acionista minoritário, na hipótese do acionista controlador ser o responsável por algumas das causas que ensejam desconsideração. De maneira que o instituto cumpre função suplementar também de proteção do próprio acionista.

Por último, tratamos ainda do patrimônio separado, isto é do conjunto de posições ativas e passivas, afetas a um fim específico. Isto como forma alternativa à idéia do capital social como reserva patrimonial apta a garantir a manutenção das atividades sociais.

Nesse caso, tendo em vista que o instituidor do patrimônio separado pode estabelecer como garantia adicional o restante do patrimônio, haverá por certo recurso às regras de tutela do capital social com esse intuito (garantia aos credores). Isto porque o capital social é elemento essencial à noção de patrimônio líquido e entendido como último recurso da companhia, quando se pensa na tutela dos credores.

Por essa razão é possível dizer, outra vez, que também o patrimônio de afetação não nega a importância do capital social, mas, pelo contrário, a complementa.

E, a despeito de toda essa discussão acerca da importância do capital social como instrumento de garantia dos credores e como elemento de manutenção da escala produtiva, é de se considerar, ainda, a função política que cumpre no cotidiano societário.

Ademais, e para finalizar, com fins a concretizar a importância do instituto, deve-se relembrar a segurança jurídica acerca da tutela do capital, porquanto o instituto é regido por rígidas regras positivadas, seja no momento da sua constituição, seja durante a vida da sociedade. 


\section{Bibliografia}

AGHIARIAN, Hércules. Curso de direito imobiliário. $6^{\mathrm{a}}$ ed. Rio de Janeiro: Lumen Júris. 2006.

ÁLVARES, Samantha Lopes. Ação de dissolução de sociedades. São Paulo: Quartier Latin, 2007.

ASCARELLI, Tullio. Problemas das sociedades anônimas e direito comparado. Campinas: Bookseller, 2001.

BARRETO FILHO, Oscar. Teoria do estabelecimento comercial: fundo de comércio ou fazenda mercantil. $2^{\mathrm{a}}$ ed. São Paulo: Saraiva, 1988.

BATALHA, Wilson. Comentários à lei das sociedades anônimas, vol. I. Rio de Janeiro: Forense, 1977.

BERLE, Adolf A. e MEANS, Gardiner C. The modern corporation and private property. New York: Hardcourt, Brace \& World, Inc., 1968.

BOBBIO, Norberto. Da estrutura à função: novos estudos de teoria do direito, trad. port. Daniela Baccaccia Versiani, rev. tec. Orlando Seixas Bechara e Renata Nagamine. Barueri: Manole, 2007.

BULGARELLI, Waldírio. Manual das sociedades anônimas. São Paulo: Atlas, 1997.

CAENEGEM, R. C. Van. Uma introdução histórica ao direito privado. $2^{\mathrm{a}}$ ed., trad. port. Carlos Eduardo Lima Machado. São Paulo: Martins Fontes, 2000.

CAMINHA, Uinie. Securitização. $2^{a}$ ed. rev. e atual. São Paulo: Saraiva, 2007.

CARDOSO, Ana Paula e RODANTE, Antonio coord. ed. Auditoria: registros de uma profissão. São Paulo: IBRACON - Instituto dos Auditores Independentes do Brasil, 2007. CARREIRA, António. A Companhia Geral do Grão-Pará e Maranhão. São Paulo: Editora Nacional, 1988.

CARVAlHOSA, Modesto. Comentários à lei de sociedades anônimas, 4 vols. São Paulo: Saraiva, 2003. e EIZIRIK, Nelson. A nova lei das S/A. São Paulo: Saraiva, 2002.

CHALHUB, Melhim Namem. Trust: perspectivas do direito contemporâneo na transmissão da propriedade para administração de investimentos e garantia. Rio de Janeiro: Renovar, 2001.

CHAVES, Natália Cristina. Direito empresarial: securitização de crédito. Belo Horizonte: Del Rey, 2006. 
COMPARATO, Fábio Konder. Direito empresarial: estudos e pareceres. São Paulo: Saraiva, 1995.

e SALOMÃO FILHO, Calixto. O poder de controle na sociedade anônima. $4^{\mathrm{a}}$ ed. Rio de Janeiro: Forense, 2005.

COSTA, Philomeno Joaquim da. Anotações às companhias, vol. I. São Paulo: Revista dos Tribunais, 1980 .

COZIAN, Maurice; VIANDIER, Alain; DEBOISSY, Florence. Droit des sociétés. $18^{\mathrm{a}}$ ed. Paris: Litec, 2005.

DANA-DÉMARET, Sabine. Le capital social. Paris: Litec, 1989.

DE LA VEGA, Joseph. Confusión de confusiones (1688). New York: John Wiley \& Sons, 1998.

DE LUCCA, Newton. A faturização no direito brasileiro. São Paulo: Revista dos Tribunais, 1986.

. Código Civil comentado. Livro II, do direito de empresa. $6^{\mathrm{a}}$ ed. São

Paulo: Saraiva, 2008.

e SIMÃO FILHO, Adalberto (coord.). Comentários à nova lei de recuperação de empresas e de falência. São Paulo: Quartier Latin, 2005.

DE ROOVER, Raymond. The Medici bank: its organization, management, operations, and decline. New York: New York University Press, 1948.

DINIZ, Gustavo Saad. Subcapitalização societária. Tese apresentada a Faculdade de Direito da Universidade de São Paulo como requisito para obtenção do título de Doutor, 2007.

DOMINGUES, Paulo de Tarso. Do capital social: noção, princípios e funções. Coimbra: Coimbra Editora, 1998.

FERRARA, Francesco. Trattato de diritto civile italiano. Roma: Athenaeum, 1921.

FERREIRA, Waldemar Martins. O direito público colonial do Estado do Brasil sob o signo pombalino. Rio de Janeiro: Nacional de Direito, 1960.

FUNDAÇÃO INSTITUTO DE PESQUISAS CONTÁBEIS, ATUARIAIS E FINANCEIRAS. Manual de contabilidade das sociedades por ações: aplicável às demais sociedades / FIPECAFI. diretor responsável Sérgio de Iudícibus; coordenador técnico Eliseu Martins; supervisor de equipe de trabalho Ernesto Rubens Gelbcke. $7^{\mathrm{a}}$ ed. $4^{\mathrm{a}}$ reimpr. São Paulo: Atlas, 2008.

GAGGINI, Fernando Schwarz. Securitização de recebíveis. São Paulo: Liv. e Ed. Universitária de Direito, 2003. 
GALGANO, Francesco. História do direito comercial, trad. port. João do Espírito Santo. Lisboa: Editores, 1980.

. Tratato di diritto commerciale e di diritto publico dell'economia, vol. VII. Padova: CEDAM, 1988.

. Lex mercatoria. Bolonha: Il Mulino, 2001.

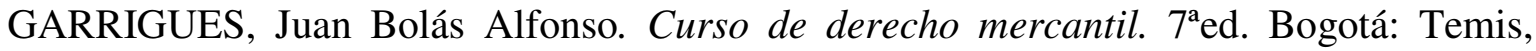
1987.

GILISSEN, John. Introdução histórica ao direito. trad. port. A. M. Hespanha e L. M. Macaísta Malheiros. Lisboa: Fundação Calouste Gulbenkian, 1995.

GOETZMANN, William N. e ROUWENHORST, Geert editores. The origins of value: the financial innovations that created modern capital markets. New York: Oxford University Press, 2005.

GUERREIRO, José Alexandre Tavares. Regime jurídico do capital autorizado. São Paulo: Saraiva, 1984.

GUYON, Yves. Droit des affaires. 12a ed. Paris: Economica, 2003.

HARRIS, Ron. Industrializing english law: entrepreneurship and business organization, 1720-1844. Cambridge: Cambridge University Press, 2000.

HEILBRONER, Robert L. The making of economic society. New Jersey: Prentice-Hall, 1962.

HENDRIKSEN, Eldon S. e VAN BREDA, Michael F. Teoria da contabilidade. trad. port. Antonio Zoratto Sanvicente. São Paulo: Atlas, 1999.

HILAIRE, Jean. Introduction historique au droit commercial. Paris: Presses Universitires de France, 1986.

KUBLER, Friedrich. The rules of capital under pressure of the securities markets in HOPT, Klaus J. e WYMEERSCH, Eddy (editors). Capital markets and company law. New York: Oxford University Press, 2003.

LAMY FILHO, Alfredo. Temas de S.A.: exposições e pareceres. Rio de Janeiro: Renovar, 2007.

e PEDREIRA, José Luiz Bulhões. A lei das S/A: pressupostos, elaboração e modificações (vol. I). $3^{\text {a }}$ ed. Rio de Janeiro: Renovar, 1997.

e PEDREIRA, José Luiz Bulhões. A lei das S/A: pressupostos, elaboração e modificações (vol. II). $2^{\mathrm{a}}$ ed. Rio de Janeiro: Renovar, 1996.

LE GOFF, Jacques. Marchands et banquiers du moyen âge. $9^{\mathrm{a}}$ ed. Paris: Press Universitaires de France, 2006. 
LEÃES, Luiz Gastão Paes de Barros. Do direito do acionista ao dividendo. São Paulo, 1969.

LISBOA, José da Silva (Visconde de Cayru). Princípios de direito mercantil e leis de marinha. Rio de Janeiro: Serviço de documentação do M.J.N.I. 1963.

LOPEZ, Robert S. The commercial revolution of the middle ages, 950-1350. Cambridge: Cambridge University Press, 2005.

MACKAY, Charles. Extraordinary popular delusions and the madness of crowds (1841). New York: John Wiley \& Sons, 1996.

MANNING, Bayless e HANKS JR., James J. Legal capital. $3^{\text {a }}$ ed. Westbury: Foundation Press, 1990.

MARCONDES MACHADO, Sylvio. Limitação da responsabilidade do comerciante individual. São Paulo: Max Limonad, 1956.

. Problemas de direito mercantil. $3^{\mathrm{a}}$ tir. São Paulo: Max Limonad,

1970.

MARCOS, Rui Manuel Figueiredo. As companhias pombalinas - contributo para a história das sociedades por acções em Portugal. Coimbra: Almedina, 1997.

MARTINS, Fran. Comentários à lei das sociedades anônimas, vol. 1. $3^{\mathrm{a}}$ ed. Rio de Janeiro: Forense, 1989.

MENDONÇA, José Xavier Carvalho de. Tratado de direito comercial brasileiro. Campinas: Bookseller, 2001.

MUNHOZ, Eduardo Secchi. Empresa contemporânea e direito societário: poder de controle e grupo de sociedades. São Paulo: Juarez de Oliveira, 2002.

NORONHA, Ilene Patrícia. Securitização de recebíveis comerciais e industriais. Tese apresentada a Faculdade de Direito da Universidade de São Paulo como requisito para obtenção do título de Doutor, 2004.

NUNES, Márcio Tadeu Guimarães. Desconstruindo a desconsideração da personalidade jurídica. São Paulo: Quartier Latin, 2007.

OLIVEIRA, José Lamartine Correia de. A dupla crise da pessoa jurídica. São Paulo: Saraiva, 1979.

OLIVEIRA, Roberto Garcia de Assis. Capital social nas sociedades limitadas: origem e evolução. Dissertação apresentada a Faculdade de Direito da Universidade de São Paulo como requisito para obtenção do título de Mestre, 2006.

PAPINI, Roberto. Sociedade anônima e mercado de valores mobiliários, $3^{\mathrm{a}}$ ed. Rio de Janeiro: Forense, 1999. 
PEDREIRA, José Luiz Bulhões. Finanças e demonstrações financeiras da companhia: conceitos e fundamentos. Rio de Janeiro: Forense, 1989.

PENTEADO, Mauro Rodrigues. Aumentos de capital das sociedades anônimas. São Paulo: Saraiva, 1988.

PEREIRA, Alexandre Demetrius. O exercício social e as demonstrações financeiras. Os lucros, as reservas e os dividendos in VERÇOSA, Haroldo Malheiros Duclerc. Curso de direito comercial, vol. 3. São Paulo: Malheiros, 2008.

PIRENNE, Henri. História econômica e social da idade média, trad. port. Lycurgo Gomes da Motta. $4^{\text {a }}$ ed. São Paulo: Mestre Jou, 1968.

PONTES, Aloysio Lopes. Instituições financeiras privadas. $2^{\mathrm{a}}$ ed. rev. aum. e atual. Rio de Janeiro: Forense, 1982.

REQUIÃO, Rubens. Aspectos modernos de direito comercial: estudos e pareceres. São Paulo: Saraiva, 1977.

Curso de direito comercial, vol. 1. 10ª ed. São Paulo: Saraiva, 1981. . Curso de direito comercial, vol. 2. 12ª ed. São Paulo: Saraiva, 1982.

RIPERT, G. e ROBLOT, R. Traité de droit commercial. 18ª éd. Paris: LGDJ, 2001.

SALOMÃO FILHO, Calixto. O novo direito societário. São Paulo: Malheiros, 2002. . A sociedade unipessoal. São Paulo: Malheiros, 1995.

SANTARELLI, Umberto. Mercanti e società tra mercanti. $2^{a}$ ed. Turim: G.Giappichelli Editore, 1992.

SICARD, Germain. Aux origines des sociétés anonymes. Les moulins de Toulouse au moyen age. Paris: Librarie Armand Colin, 1953.

VALVERDE, Trajano de Miranda. Sociedades por ações (comentários ao decreto-lei $n^{o}$ 2627, de 26 de Setembro de 1940), vol. I a III. $3^{\text {a }}$ ed. Rio de Janeiro: Forense, 1959.

VERÇOSA, Haroldo Malheiros Duclerc. Curso de direito comercial, vol. 1. São Paulo: Malheiros, 2004. . Curso de direito comercial, vol. 2. São Paulo: Malheiros, 2006. . Curso de direito comercial, vol. 3. São Paulo: Malheiros, 2008.

VIVANTE, Cesare. Tratatto di diritto commerciale, vol. II. Milano: Vallardi, 1929. . Instituições de direito comercial. Campinas: Editora Minelli, 2006.

WARDE JÚNIOR, Walfrido Jorge. Responsabilidade dos sócios: a crise da limitação e a teoria da desconsideração da personalidade jurídica. Belo Horizonte: Del Rey, 2007. WEBER, Max. The history of commercial partnerships in the middle ages. translated and introduced by Lutz Kaelber. New York: Rowman \& Littlefield Publishers, Inc., 2003. 
. General economic history. translated by Frank H. Knight. New York:

Dover Publications, Inc., 2003.

WIACKER, Franz. História do direito privado moderno. trad. port. A. M. Botelho Hespanha. $2^{a}$ ed. Lisboa: Fundação Calouste Gulbenkian, 1980.

\section{$\underline{\text { ARTIGOS }}$}

AGHIARIAN, Hércules. Patrimônio de afetação in Boletim de Doutrina ADCOAS. São Paulo, v. 8, no 3, pp. 55/60, fev. 2005.

ALONSO LEDESMA, Carmen. Algunas reflexiones sobre la función (la utilidad) del capital social como técnica de protección de los acreedores. In Estudios de Derecho de Sociedades y Derecho Concursal: libro homenaje al Profesor Rafael García Villaverde. Madri: Marcial Pons, pp. 127/157. Disponível em:

http://eprints.ucm.es/7728/1/03a_ALONSO_LEDESMA\%E2\%80\%A2.pdf. Acesso em 26/09/08.

AMARO, Luciano da Silva. Desconsideração da pessoa jurídica no Código de Defesa do Consumidor in Revista de Direito Mercantil, Industrial, Econômico e Financeiro. São Paulo, no 88, pp. 70/80, out./dez. 1992.

ASCARELLI, Tullio. A atividade do empresário, trad. port. Erasmo Valladão Azevedo e Novaes França in Revista de Direito Mercantil, Industrial, Econômico e Financeiro. São Paulo. v. 42. no 132. pp. 203/215, out./dez. 2003.

ASQUINI, Alberto. Una svolta storica nel diritto commerciale, in Rivista del Diritto Commerciale e del Diritto Generale delle Obbligazioni. Milano, v. XXXVIII, parte prima, 1940.

Perfis da empresa, trad. port. Fábio Konder Comparato in Revista de Direito Mercantil, Industrial, Econômico e Financeiro. São Paulo, v. 35, nº 104, pp. 109/126, out./dez. 1996

BORGES, Luiz Pereira Xavier. Securitização como parte da segregação de risco empresarial in Revista de Direito Bancário, do Mercado de Capitais e da Arbitragem. São Paulo, v. 3, nº 10, pp. 257/267, out/dez. 2000.

CANFIELD, George F. The scope and limits of the corporate entity theory in Columbia Law Review. New York, Columbia University, v. XVII, pp. 128/143, 1917.

CHALHUB, Melhim Namen. A incorporação imobiliária com patrimônio de afetação: a teoria da afetação e sua aplicação às incorporações imobiliárias. Comentários à medida 
provisória 2.221, de 04.09.2001 in Revista de Direito Imobiliário. São Paulo, v. 26, nº 55, pp. 62/104, jul./dez. 2003.

FERRO-LUZZI, Paolo. La disciplina dei patrimoni separati in Rivista della società. Milano, v. 47, nº 1, pp. 121/138, genn./febb. 2002.

FRANÇA, Erasmo Valladão Azevedo e Novaes. Empresa, empresário e estabelecimento. A nova disciplina das sociedades in Revista do Advogado, São Paulo, ano XXIII, $\mathrm{n}^{\circ}$ 71, pp. $15 / 25$, agosto de 2003 .

HANSMANN, Henry, KRAAKMAN, Reinier e SQUIRE, Richard. Law and the Rise of the Firm. Disponível em: http://www.usc.edu/schools/college/crcc/private/ierc/Law and the Rise of the Firm.pdf. Acesso em 16/09/07.

KRIGER FILHO, Domingos Afonso. Aspectos da Desconsideração da Personalidade Societária na Lei do Consumidor in Revista de Direito do Consumidor, São Paulo, $\mathrm{n}^{\circ} 13$, pp. 78/86, jan./mar. 1995 .

LAMY FILHO, Alfredo. Capital social. Conceito. Atributos. A alteração introduzida pela Lei $n^{\circ}$ 9.457/97. O capital social no sistema jurídico americano in Revista Forense, Rio de Janeiro, v. 346, pp. 3/7, abril/maio/junho 1999.

MARINONI, Luiz Guilherme e LIMA JÚNIOR, Marcos Aurélio. Fraude - Configuração -Prova - Desconsideração da personalidade jurídica in Revista dos Tribunais. São Paulo: ano 90, v.783, pp. 137/164, jan. 2001.

MURPHY, Antoin E. John Law: innovating theorist and policymaker in The origins of value: the financial innovations that created modern capital markets. Oxford: Oxford Press, 2005 , pp. $225 / 248$.

NORONHA, Fernando. Patrimônios especiais: sem titular, autônomos e coletivos in Revista dos Tribunais, v. 87, $\mathrm{n}^{\circ}$ 747, pp. 11/34, janeiro de 1998.

PENTEADO JUNIOR, Cássio Martins C. A afetação do patrimônio como exceção ao princípio de sua universalidade - conteúdo jurídico e efeitos in Revista de Direito Bancário, do Mercado de Capitais e da Arbitragem. São Paulo. v. 5. nº 16. pp. 102/111. abr./jun. 2002.

A securitização de recebíveis de créditos gerado em operações dos bancos: a Resolução n. 2493 e sua perspectiva jurídica in Revista de Direito Mercantil, Industrial, Econômico e Financeiro, São Paulo, v. 36, nº 111, pp. 120/124, jul./set. 1998.

REQUIÃO, Rubens. Abuso de direito e fraude através da personalidade jurídica (Disregard Doctrine) in Revista dos Tribunais. São Paulo: ano 58, v.410, pp. 12/24, dez. 1969. 
ROCHA, João Luiz Coelho da. Patrimônio de afetação nas incorporações imobiliárias in Boletim de Doutrina ADCOAS. São Paulo, v. 8, n 4, pp. 73/74, fevereiro de 2005.

SALOMÃO FILHO, Calixto. "Societas” com relevância externa e personalidade jurídica in Revista de Direito Mercantil, Industrial, Econômico e Financeiro. São Paulo, no 81, pp. 66/78, jan./mar. 1991.

SILVA, Alexandre Couto e. Desconsideração da personalidade jurídica: limites para sua aplicação in Revista dos Tribunais. São Paulo: ano 89, v.780, pp. 47/58, out. 2000.

STUBER, W. D.; BENTIVEGNA, E. J.; FILIZZOLA, H. B. O instituto de securitização de créditos do Brasil in Revista Tributária e de Finanças Públicas. São Paulo, v.8., no 32, maio/jun. 2000.

STURZENEGGER, Luiz Carlos. A doutrina do "patrimônio de afetação" e o novo sistema de pagamentos brasileiro in Revista de Direito Bancário, do Mercado de Capitais e da Arbitragem. São Paulo, v. 4, nº 11, pp. 229/244, jan./mar. 2001.

SZTAJN, Rachel. Sobre a desconsideração da personalidade jurídica in Revista dos Tribunais. São Paulo: ano 88, v.762, pp. 81/97, abr. 1999.

TUTIKIAN, Cláudia Fonseca. Patrimônio de afetação na incorporação imobiliária in Revista Síntese de Direito Civil e Processual Civil. Porto Alegre, v. 6, n 31. pp.46/55, set./out. 2004.

ZOPPINI, Andréa. Autonomia e separazione del patrimônio, nella prospettiva del patrimoni separati della società per azioni in Rivista di Diritto Civile. Padova, v. 48, $\mathrm{n}^{\circ} 4$, pp. 545/575, lug./ago. 2002.

WILLISTON, Samuel. History of the law of business corporations before 1800 in Harvard Law Review. Cambridge, v. II, nº 3, pp. 105/124, oct. 15, 1888. 